NBER WORKING PAPER SERIES

WHAT DOES CODETERMINATION DO?

\author{
Simon Jäger \\ Shakked Noy \\ Benjamin Schoefer
}

Working Paper 28921

http://www.nber.org/papers/w28921

\author{
NATIONAL BUREAU OF ECONOMIC RESEARCH \\ 1050 Massachusetts Avenue \\ Cambridge, MA 02138 \\ June 2021, Revised October 2021
}

We thank Nelson Mesker for excellent research assistance and Tommy O'Donnell for help with the draft. We thank the editor Lawrence Kahn, two referees, Elizabeth Anderson, David Autor, Gabriel Burdín, Markus Helfen, Andrew Linden, Ewan McGaughey, Steffen Müller, Robert Scholz, and Alan Yan for helpful comments. We thank Sjaak van der Velden for sharing compiled and digitized versions of the ILO data with us. Jäger thanks the MIT Policy Lab for financial support. The views expressed herein are those of the authors and do not necessarily reflect the views of the National Bureau of Economic Research.

NBER working papers are circulated for discussion and comment purposes. They have not been peerreviewed or been subject to the review by the NBER Board of Directors that accompanies official NBER publications.

(C) 2021 by Simon Jäger, Shakked Noy, and Benjamin Schoefer. All rights reserved. Short sections of text, not to exceed two paragraphs, may be quoted without explicit permission provided that full credit, including $\odot$ notice, is given to the source. 
What Does Codetermination Do?

Simon Jäger, Shakked Noy, and Benjamin Schoefer

NBER Working Paper No. 28921

June 2021, Revised October 2021

JEL No. J08,K31,M1,M5

\begin{abstract}
$\underline{\text { ABSTRACT }}$
We provide a comprehensive overview of codetermination, i.e., worker representation in firms' governance and management. The available micro evidence points to zero or small positive effects of codetermination on worker and firm outcomes, and leaves room for moderate positive effects on productivity, wages, and job stability. Similarly, we present new country-level, general-equilibrium event studies of codetermination reforms between the 1960s and 2010s, finding no effects on aggregate economic outcomes or the quality of industrial relations. We offer three explanations of the institution's limited impact. First, existing codetermination laws convey little authority to workers. Second, countries with codetermination laws have high baseline levels of informal worker voice. Third, codetermination laws may interact with other labor market institutions, such as union representation and collective bargaining. We close by discussing implications for recent codetermination proposals in the United States.

Simon Jäger

Department of Economics, E52-454

MIT

77 Massachusetts Avenue

Cambridge, MA 02139

and IZA

and also NBER

sjaeger@mit.edu

Shakked Noy

Massachusetts Institute of Technology

Cambridge, MA 02140

shakked.noy@gmail.com

Benjamin Schoefer

Department of Economics

University of California, Berkeley

530 Evans Hall \#3880

Berkeley, CA 94720-3880

and NBER

schoefer@berkeley.edu
\end{abstract}


Under the dominant model of corporate governance in the United States, firms are controlled by their shareholders or owners, and are governed with the exclusive objective of maximizing the welfare of those shareholders or owners. In the past several years, amid rising inequality, a declining labor share, and growing concerns about employer power, interest in alternative systems of corporate governance has risen rapidly. In particular, the European model of "codetermination," under which control of firms is shared between shareholders and workers, has received a great deal of attention. Since 2018, the U.S. Democratic Party, the British and Canadian Conservative Parties, and the British and Australian Labour Parties have proposed or expressed interest in codetermination legislation; prominent academics have called for a democratization of the workplace; and the U.S. Business Roundtable and World Economic Forum have distanced themselves from the doctrine of "shareholder primacy.'11

A priori, codetermination could have dramatic positive or negative effects on worker and firm outcomes. Opponents of codetermination argue that involving workers in firm governance distorts incentives away from the maximization of economic surplus and leads to "hold-up" problems that deter capital investment and cause production to stagnate, leaving shareholders worse off as profits vanish, workers worse off as wages fall, and consumers worse off as prices rise. Proponents of codetermination, on the other hand, emphasize the ability of shared governance to reduce imbalances of power in the workplace, incentivize worker investment in firm-specific human capital, and facilitate information sharing. In the public debate, recent codetermination proposals such as the Accountable Capitalism Act have been lauded by some commentators as a necessary check on the excesses of American shareholder capitalism (Yglesias, 2018; Vogel, 2019; Cass, 2020), and decried by others as inevitably disastrous for innovation and economic growth (Hammond, 2018; Shackford, 2018; Williamson, 2018).

This paper contributes to the ongoing debate by providing a comprehensive overview of European codetermination, covering institutional details, the best available evidence on economic impacts, and qualitative evidence on how shared governance operates in practice.

\footnotetext{
${ }^{1}$ In the U.S., the Reward Work Act and Accountable Capitalism Act, proposed by Democratic senators in 2018, would require $33 \%$ or $40 \%$ of seats on the boards of large companies to be allocated to workers. In the United Kingdom, the Conservative leader Theresa May called for worker representation on company boards during the 2016 election campaign (The Guardian, 11/12/16), and the Labour Party's platform in 2018 included a proposal for 33\% worker representation on the boards of companies with more than 250 workers (Reuters, 09/23/2018). In the 2021 Canadian election campaign, the Conservative leader Erin O'Toole proposed requiring federally regulated companies to elect worker representatives to their boards (Globe and Mail, 08/23/2021). In 2019, the Australian Labour Party said it was considering various codetermination proposals (Sydney Morning Herald, 11/07/2019). The Business Roundtable and World Economic Forum issued statements in 2019 expressing support for stakeholder governance (a system of corporate governance in which firms have an obligation to serve non-shareholder stakeholders, such as workers).
} 


\section{What is Codetermination?}

\subsection{Shareholder Control versus Codetermination}

In the U.S. and other liberal market economies, ultimate control over a firm's governance is concentrated in the hands of its shareholders or owners, who make major strategic decisions and appoint and oversee managers responsible for the firm's day-to-day operations. Under the dominant legal doctrine of "shareholder primacy," popularized by Friedman (1970), shareholders or owners govern firms with the sole purpose of maximizing their own welfare; typically, this is understood to mean maximizing long-term profits or dividend payouts. By contrast, under codetermination, a firm's shareholders and workers share control over major strategic decisions, and managers and workers share control over day-to-day decision-making. Figure 1 visualizes the differences between shareholder control and codetermination.

Arguments for Shareholder Control Proponents of exclusive shareholder control argue that shareholders or owners are the only actors naturally incentivized to grow the value of the firm - as they are the residual claimants on a firm's profits after all contractual obligations are met-and consequently giving them control of corporate governance fosters economic growth (Hansmann and Kraakman, 2000). In particular, supporters of shareholder control warn that, by boosting workers' influence over wage-setting and allowing them to capture increases in surplus for themselves, codetermination deters investment (in a classic "hold-up" mechanism), leaving everyone worse off:

[T] he workers will begin 'eating [the firm] up' by transforming the assets of the firm into consumption or personal assets. [...] It will become difficult for the firm to obtain capital in the private capital markets. [...] The result of this process will be a significant reduction in the country's capital stock, increased unemployment, reduced labor income, and an overall reduction in output and welfare. (Jensen and Meckling, 1979, p.504)

Arguments for Codetermination In contrast, proponents of codetermination offer a number of theoretical arguments. First, codetermination rights may act as an antidote for power imbalances between employers and workers, preventing exploitation, abuse, and underpayment of workers (Frege and Godard, 2014; Anderson, 2017). Second, shared governance may increase worker effort and investment in firm-specific human capital (Malcomson, 1983; Furubotn, 1988: Smith, 1991; Freeman and Lazear, 1995; Strine Jr. 2002). In an influential class of models, asymmetric information or limitations on contracting force firms to rely on implicit promises of future promotions and pay rises in order to encourage workers to expend effort or develop their firm-specific skills (see, e.g., Lazear, 1979; Carmichael, 1983). Codetermination can help 
make these implicit promises credible, exactly because workers are involved in governance. Third, codetermination may facilitate and incentivize information-sharing, which can improve both worker satisfaction and firm performance (Hirschman, 1970; Freeman and Lazear, 1995).

Proponents of codetermination also offer theoretical and institutional retorts to a key challenge posed by advocates of the shareholder primacy view: since profit-maximizing firms appear not to voluntarily adopt codetermination, it must not be a joint-surplus-maximizing institution and can only be implemented by government fiat (Jensen and Meckling, 1979). Defenders of codetermination reply that employers would not voluntarily give up power that lets them extract rents from workers even if doing so increased the size of the joint pie (Freeman and Lazear, 1995), that prisoner's dilemmas can prevent firms from unilaterally adopting codetermination even if an economy-wide imposition would be socially beneficial (Levine and Tyson, 1990; Hayden and Bodie, 2021), and that information asymmetries or other frictions may forestall the bargaining necessary for voluntary adoptions (Jirjahn and Smith, 2018). Finally, some jurisdictions impose legal constraints on the voluntary adoption of codetermination-e.g., the National Labor Relations Act in the U.S. imposes stark limits on codetermination arrangements.

\subsection{Existing Codetermination Laws}

Codetermination is most widely practiced in Europe, where many countries have passed codetermination laws that apply to firms above certain size thresholds. These laws typically require covered firms to adopt, or give their workers the right to demand, board-level worker representation, shop-floor worker representation, or both.

Board-Level Representation Under board-level representation, a share of seats on company boards are allocated to worker-elected representatives (Gold and Waddington, 2019). These representatives are given the same rights as other board members, meaning that workers receive a vote on major company decisions and on the appointment and supervision of senior managers. Board-level representation laws are virtually unique to Europe, as Appendix Figure A.1illustrates using data from the CBR Labor Regulation Index (Adams, Bishop, and Deakin. 2016).

Existing board-level representation laws almost always grant workers a minority position on the board-usually $20-40 \%$ of the seats (ETUI, 2020). The notable exception is Germany: while German firms with between 500 and 2,000 employees must allocate only 33\% of board seats to workers, firms with over 2,000 employees are subject to "quasi-parity" representation, meaning that $50 \%$ of seats go to workers, but shareholders receive a tie-breaking vote. Uniquely to Germany and for historical reasons going back to the aftermath of World War II, firms with more than 1,000 employees in the iron, coal, and steel sectors are subject to full parity 
representation, with no casting vote for shareholders.

Shop-Floor Representation Under shop-floor representation, workers elect establishmentlevel representatives who participate in day-to-day firm governance, with the details of this participation varying across countries and firms. Shop-floor representation laws are widespread even outside of Europe, as Appendix Figure A.2 illustrates, again using CBR Labor Regulation Index data. In addition, shop-floor representation laws typically apply already to small- and medium-sized firms-for example, in Germany, shop-floor representation rights apply to any establishment with 5 or more workers (Addison, 2009).

Shop-floor representation laws vary widely in the formal authority they give to worker representatives. Employers are usually required to inform and consult shop-floor representatives in advance about decisions regarding working hours, working conditions, or the recruitment, transfer, or dismissal of employees (Aumayr, Stavroula, Foden, Scepanovics, and Wolf, 2011). These requirements do not convey any substantive authority to workers, but may create implicit pressure on employers to reach a consensus with workers. Some countries additionally give shop-floor representatives narrow rights to appeal to employment courts to overturn employer decisions (Van het Kaar, 1997; Visser, 2021).

Several countries, including Germany, Austria, Sweden, Norway, and the Netherlands, grant shop-floor representatives more substantive co-decision-making powers (Visser. 2021). For example, in Germany, shop-floor "works councils" have a right to participate in decisions about working hours, leave arrangements, the introduction of productivity-monitoring technology, and performance-related pay (Addison, Schnabel, and Wagner, 2001). They can also veto "unwarranted" dismissals of staff, in which case the employer must bring a case to a labor court if they wish to override the veto. German works councils also serve as the bargaining party representing workers in establishment- or firm-level negotiations, including over wages, when opening clauses allow for local deviations from sectoral agreements. Meanwhile, Austrian shop-floor representatives have co-decision-making rights in the areas of working hours, disciplinary procedures, workplace monitoring technologies, and performance pay schemes, and can force external arbitration in a wider range of areas (Aumayr, Stavroula, Foden, Scepanovics, and Wolf, 2011; ETUI, 2020). Swedish and Norwegian law requires employers to negotiate extensively with shop-floor representatives before implementing major changes to working conditions. In the Netherlands, most changes to workplace regulations (for example, changes to pension schemes, or hours/leave arrangements) must be approved by shop-floor representatives (ETUI, 2020).

Differences Board-level and shop-floor codetermination perform different and plausibly complementary functions: board-level representation lets workers participate in high-level strategic decisions, while shop-floor representation involves workers in day-to-day man- 
agement. Moreover, while all board-level representation laws give similar generic powers, shop-floor representation laws are extremely heterogeneous, especially in the specific decisionmaking rights they allocate.

\subsection{Codetermination, Unions, and Collective Bargaining}

Codetermination arrangements are systems of cooperative shared governance between employers and worker representatives and are hence conceptually distinct from adversarial collective bargaining between employers and labor unions. Nevertheless, the two kinds of worker representation are closely interrelated: most countries with codetermination laws also have high union density and strongly centralized collective bargaining frameworks, as Panels (a), (b), and (e) of Figure 2 illustrate using data from the OECD/IAIS ICTWSS database (Visser, 2021).

In the Nordic countries, the two kinds of worker representation are inextricably intertwined: most workplaces have union representatives who report back to the industry- or national-level unions responsible for sectoral collective bargaining negotiations, and "codetermination" simply consists of the allocation of special co-decision-making rights to these local union representatives (ETUI, 2020). This bundling is a product of the fact that, historically, sharedgovernance rights in these countries were secured through the efforts of national unions wanting to extend the mandates of their representatives beyond the narrow issues regulated by collective bargaining (Jäger, Noy, and Schoefer, 2021). By contrast, in countries like Germany or Austria with "dual channel" models of worker representation, there is a clear legal separation between codetermination and union representation (Addison, 2009), though in practice the institutions interact closely (Gumbrell-McCormick and Hyman, 2013). In the German context specifically, legal separation of unions and codetermination can be traced back to reforms in the 1950s aimed at weakening unions by cutting off their access to shared governance rights (Thelen, 1991: Silvia, 2013).

Firm-level shared governance arrangements in Germany, Austria, and the Nordic countries are also nested within sectoral collective bargaining agreements negotiated between unions and employer associations. These agreements set industry-level minimum requirements for wages and working conditions and provide a backdrop for firm-level negotiations between employers and worker representatives. We discuss potential interactions in much more detail in Sections 5 and 6 . 


\section{Job Quality: Do Workers Benefit from Codetermination?}

\subsection{Sources of Evidence}

There is a large empirical literature studying the firm-level effects of codetermination on worker outcomes, chiefly from the 1980s to 2000s examining German codetermination (see Conchon, 2011, for a summary of papers on German board-level representation and Addison. 2009, Jirjahn and Smith, 2018, and Schnabel, 2020, for summaries of papers on German shop-floor representation). These studies compare the outcomes of workers in firms with versus without codetermination, or in industries subject to more stringent versus less stringent codetermination requirements, controlling for the influence of some confounding variables.

Given the vulnerability of the aforementioned research designs to omitted variable bias, the ideal research design to study the causal effects of codetermination is an experiment that randomly imposes codetermination in some firms (or some economies) but not in others. In our review of the evidence, we place heavier weight on research designs we judge to more credibly approximate the ideal laboratory experiment. We particularly draw on two studies that use "natural experiments" and large micro data sets on individual firms and workers to approximate this ideal design. First, Jäger, Schoefer, and Heining (2021) study the 1994 abolition of minority board-level representation requirements in new shareholder corporations in Germany. Second, Harju, Jäger, and Schoefer (2021) study a 1990 introduction of minority board-level representation rights in Finnish firms with 150 or more employees, and a 2008 expansion of shop-floor representation rights to Finnish firms with between 20 and 30 employees. Both studies exploit the selective coverage of the codetermination reforms, and compare the outcomes of firms covered by the reforms to the outcomes of similar firms not covered, in a difference-in-differences framework.

\subsection{Impacts on Worker Outcomes}

Wages and Rent-Sharing Codetermination might increase wages by expanding workers' influence and thereby boosting their bargaining power, or could decrease wages by worsening firm performance and reducing joint surplus.

Recent studies find either no effects, or very small positive effects, of board-level representation on wages and the sharing of profits with workers. Jäger, Schoefer, and Heining (2021) and Harju, Jäger, and Schoefer (2021) find statistically insignificant wage increases of $1.0 \%$ and $1.6 \%$ as a result of board-level representation in Germany and Finland, and no evidence for increases in rent-sharing, i.e., the firm-level elasticity of wages to productivity (95\% CIs for those point estimates are $-1.9 \%$ to $3.9 \%$ and $-0.2 \%$ to $3.4 \%$, respectively). Blandhol, Mogstad, 
Nilsson, and Vestad (2020) find zero wage effects of board-level representation in Norway 2

Evidence on the wage effects of shop-floor representation is more mixed but still points towards zero or at best small positive effects. Keskinen (2017) and Harju, Jäger, and Schoefer (2021) find zero wage effects of Finnish shop-floor representation. Meanwhile, an older literature on German works councils produced mixed results (Addison, 2009), while more recent studies find small positive effects on wages and moderate reductions in within-firm earnings inequalities (Jirjahn and Smith, 2018; Hirsch and Mueller, 2020; Schnabel, 2020). The latter findings may reflect the particular strength of German works councils, which hold a variety of substantive co-decision-making rights and can also represent workers in firm-level wage negotiations, e.g., if no sectoral bargaining agreement applies or if the agreement includes opening clauses ( $\$ 87$ Betriebsverfassungsgesetz).

Separations and Job Security Codetermination could plausibly reduce job separations. On the voluntary side, a key prediction of the "exit-voice" framework (Hirschman, 1970) is that giving dissatisfied workers an avenue to change their firm from within will reduce quits. Additionally, if codetermination increases job quality, it should raise retention. On the involuntary side, worker representatives may strive to protect incumbent workers from dismissal—either by lobbying against planned layoffs at the board level, or by using shop-floor co-decision-making rights to resist dismissal decisions.

The existing literature suggests that board-level codetermination does not affect voluntary separations and may slightly reduce involuntary separations. Jäger, Schoefer, and Heining (2021) find no effects of German board-level representation on overall turnover, while Harju, Jäger, and Schoefer (2021) find that Finnish board-level representation does not affect employment-to-employment ("voluntary") separations but does cause a 2 percentage point decline in employment-to-nonemployment ("involuntary") separations. Kim, Maug, and Schneider (2019) find that workers in German firms with quasi-parity representation are insulated from layoffs in exchange for earning slightly lower wages, consistent with an insurance arrangement.

For shop-floor representation, Harju, Jäger, and Schoefer (2021) find no effects of Finnish shop-floor representation on separations, but a large literature on German works councils finds associations with lower voluntary and involuntary separations (Addison, Schnabel, and Wagner, 2001; Hirsch, Schank, and Schnabel, 2009; Adam, 2019). As we have mentioned, this may be due to the exceptional power of German works councils, including the right to block dismissals and force the employer to a labor court.

One way that codetermination might reduce involuntary dismissals is by reducing down-

${ }^{2}$ These studies examine minority board representation. Interestingly, two studies of quasi-parity and parity representation in Germany suggest moderate wage effects, but in opposite directions (Svejnar. 1981: Kim, Maug, and Schneider. 2019). 
ward wage rigidity and hence facilitating wage and hours cuts, instead of layoffs, during crises (Rehder, 2003: Burdín and Dean, 2009; Gregoric and Rapp, 2019). A seat at the table may allow workers to verify when economic conditions genuinely necessitate wage cuts, overcoming reflexive distrust of proposed reductions in compensation.

High job security of incumbent workers may come at the expense of hiring, in a standard insider-outsider mechanism (Lindbeck and Snower, 1989). Indeed, there is evidence that shop-floor representation causes Finnish and German firms to reduce their hiring (Keskinen, 2017: Gralla and Kraft. 2018). However, there is also evidence in the opposite direction; Jirjahn (2010) finds that German shop-floor representation is associated with higher employment growth, and Burdín and Dean (2012) show that worker-managed firms in Uruguay do tend to prioritize employment growth.

Subjective Wellbeing, Health and Other Difficult-to-Observe Outcomes Existing studies often cannot speak to hard-to-measure outcomes such as abuse or mistreatment of workers, feelings of dignity, or workplace health and safety. Harju, Jäger, and Schoefer (2021) find that both Finnish board-level and shop-floor representation moderately increase subjective job satisfaction. They find no effects on sick leaves, while Arnold, Brändle, and Goerke (2018) document higher sick leave in German firms with works councils. Overall, the evidence on non-pecuniary aspects of job quality remains sparse.

Conclusion The existing microeconometric evidence suggests zero or small positive effects of codetermination on proxies for worker welfare. Codetermination has, at most, small positive impacts on wages; it may reduce voluntary separations, and likely reduces involuntary dismissals, with mixed evidence on offsetting effects on hiring; and some suggestive and limited evidence points towards increases in subjective job quality.

\section{Firm Performance: Do Shareholders Suffer (or Benefit) from Codetermination?}

We now discuss the effects of codetermination on firm-level outcomes, like firm survival, productivity, revenue, and investment.

Microeconometric Evidence Jäger, Schoefer, and Heining (2021) and Harju, Jäger, and Schoefer (2021) find that German and Finnish board-level representation have zero or even slightly positive (statistically insignificant) effects on productivity, capital intensity, firm survival, labor productivity, revenue, and profitability. These findings are consistent with an older, mostly correlational, literature on German board-level representation, which finds on 
average zero effects. For example, of the 30 studies surveyed by Conchon (2011), 10 find a positive effect on firm performance, 11 find no effect, and 9 find a negative effect. ${ }^{3}$

For shop-floor representation, the reform-based, quasi-experimental studies of Finnish shop-floor representation by Keskinen (2017) and Harju, Jäger, and Schoefer (2021) find no effects on firm performance. Older studies of German shop-floor representation find mixed results (Addison, Schnabel, and Wagner, 2004; Addison, 2009), while newer studies find generally positive associations between works councils and productivity and profitability (Mueller, 2012; Mueller and Stegmaier, 2017; Jirjahn and Smith, 2018; Mueller and Neuschaeffer. 2020; Schnabel, 2020). Moreover, specifically rejecting the "hold-up" mechanism, German firms with works councils do not have lower capital investment (Addison, Schank, Schnabel, and Wagner, 2007).

Revealed-Preference Evidence In many settings, firms can avoid codetermination requirements if determined to do so. First, codetermination laws typically apply only to firms above a certain size threshold, meaning that firms just above the threshold can evade mandates by manipulating their size, including by outsourcing employment or shifting their organizational structure. Second, many codetermination laws give workers an optional right to codetermination; if codetermination worsens firm performance and thereby reduces overall surplus, employers could bargain workers into forgoing their right.

Systematic studies have found no empirical evidence that firms manipulate their size in order to avoid codetermination requirements. For example, Lin, Schmid, and Xuan (2018), Kim, Maug, and Schneider (2019), Redeker (2019), Blandhol, Mogstad, Nilsson, and Vestad (2020), Jäger, Schoefer, and Heining (2021), and Harju, Jäger, and Schoefer (2021), covering firms in Germany, Norway, and Finland, find no evidence that firms bunch just below the relevant size thresholds-in contrast to bunching that does appear in response to other size-dependent policies that impose costs on firms (Garicano, Lelarge, and Van Reenen, 2016). 4 These facts provide revealed-preference evidence that codetermination does not substantially harm firm performance, at least among firms close to the thresholds.

${ }^{3} \mathrm{~A}$ few of these studies have used event study or regression discontinuity designs to analyze effects, e.g., on stock market valuations. For example, Gorton and Schmid (2004) document a negative effect on stock market valuation comparing firms above and below the 2,000 employee cutoff, i.e., comparing firms with one-third vs. quasi-parity representation. By contrast, Baums and Frick (1998) find no effect on stock market valuation using an event study methodology of court decisions regarding codetermination in individual firms (similarly, Bermig and Frick. 2010, find no effect on firm performance or valuation controlling for firm fixed effects).

${ }^{4}$ We note a tension between the absence of bunching at the 2,000 employee policy threshold in Germany, the threshold for quasi-parity rather than one-third board-level codetermination, documented in several papers (Lin, Schmid, and Xuan, 2018: Kim, Maug, and Schneider. 2019: Redeker. 2019) and the findings in Gorton and Schmid (2004), who document sharp declines in stock market valuation comparing firms above and below the policy threshold (but do not implement a McCrary, 2008, test). That is, if quasi-parity codetermination indeed had sharp negative effects on profitability or stock market valuations, then one would expect significant bunching at the 2,000 employee threshold. In turn, no bunching would make sharp declines in stock market valuations surprising. 
The evidence on workers' take-up of codetermination is less conclusive. On average, workers in about $50 \%$ of firms subject to codetermination rights end up taking up their statutory rights (Addison, Schnabel, and Wagner, 1997; Gregoric and Rapp, 2019; Harju, Jäger, and Schoefer, 2021). When Finnish workers in eligible firms are asked why they have not exercised their statutory right, the most common response is that the employer opposed it (Harju, Jäger, and Schoefer, 2021). Given that Harju, Jäger, and Schoefer (2021) find no evidence for increases in compensation indicative of bilateral bargains, this suggests that some employers can and do unilaterally block take-up of codetermination rights, perhaps fearing negative effects on firm performance.

Surveys of Managers' and Directors' Attitudes If codetermination worsens firm performance, managers and directors should hold negative attitudes towards it. In contrast, Levinson (2000) reports that $76 \%$ of Swedish Corporate Directors hold "positive" or "very positive" views of codetermination, with $19 \%$ having a neutral view and only $5 \%$ having a negative view. In the Netherlands, about $80 \%$ of managers think shop-floor representation has a neutral impact on efficiency and innovation, with $5-10 \%$ estimating a positive effect and 10-15\% estimating a negative effect (Van Den Berg, Grift, and Witteloostuijn, 2000). Paster (2012) reports that $71 \%$ of German executives oppose the abolition of mandatory minority board-level representation (though executive perceptions of quasi-parity and parity board representation are more negative, and employer associations officially oppose all board-level representation mandates; Stettes, 2007; Paster, 2012).

Conclusion The existing literature suggests that codetermination is a broadly benign institution from the perspective of firm performance. There is little credible microeconometric evidence for negative effects, and there is revealed-preference and survey evidence that would be hard to square with managers and directors strongly objecting to the institution.

\section{General-Equilibrium Effects of Codetermination Laws}

The microeconometric studies surveyed above estimate the effects of codetermination on individual firms covered by codetermination laws, compared to uncovered firms. However, codetermination laws might also have-or even primarily work through—general-equilibrium effects that cannot be picked up by comparisons of firms on either side of the margins of coverage of codetermination laws. Competition in product, factor, or financial markets may prevent the formation of a wedge between the outcomes of codetermined and non-codetermined firms, and mean that codetermination laws shift worker outcomes only insofar as they shift a market's overall competitive equilibrium (Levine and Tyson, 1990). Similarly, codetermination 
laws might shape a country's overall industrial relations: formal institutionalization of worker-management cooperation in large firms could have cultural spillover effects that create economy-wide norms of worker participation or make industrial relations more cooperative and friendly (Thelen, 1991).

We are not aware of existing empirical evidence on the general-equilibrium impacts of codetermination laws, with the exception of a few industry-level studies (Svejnar. 1981) and cross-sectional regressions (Hörisch, 2012). We therefore present new estimates of the countrylevel effects of codetermination laws, using a cross-country event study design exploiting major codetermination reforms. Appendix Sections B.1 B.7 detail the methodology summarized below.

Sample and Identifying Variation We restrict our attention to European countries with non-missing data that were independent and democratic between 1960 and 2019: Austria, Belgium, Denmark, Finland, France, Germany, Iceland, Ireland, Italy, the Netherlands, Norway, Sweden, Switzerland, and the United Kingdom. We exploit ten introductions or expansions of codetermination occurring between 1960 and 2019: introductions of board-level representation in Austria, Denmark, Finland, France, and Norway; a switch from one-third to quasi-parity board-level representation in large firms in Germany; and expansions of shop-floor representation rights in Finland, the Netherlands, Norway, and Sweden (for Finland and Norway, we study both the board-level and shop-floor reforms as separate reforms). Notably, this list excludes some minor reforms (e.g., in Italy). Appendix Section B.1 elaborates on our sample and reforms.

Estimation Strategy For each country-reform event, we construct a synthetic control unit out of the other countries in our sample that do not experience a reform within a 10-year radius around that reform event. Synthetic control weights are calculated by matching on pre-reform macroeconomic characteristics (GDP growth, wage growth, TFP growth, the labor share, and net capital formation). We then estimate stacked event study specifications by pooling our country-reform units and synthetic control units, aligned by event time, and running difference-in-differences regressions comparing the outcomes of the treated and synthetic control groups before and after the codetermination reforms. The regression equation is:

$$
y_{i k}=\alpha_{i}+\beta_{k}+\theta_{\text {Year }(i k)}+\sum_{s=-10, s \neq-1}^{10} \tau_{s}^{\text {Treated }} \times \mathbb{1}[k=s] \times \operatorname{Treated}_{i}+\varepsilon_{i k}
$$

where $y_{i k}$ denotes the outcome for country-reform $i$ in year $k=t-$ reformyear $_{i}$ relative to the reform occurring in reformyear ${ }_{i}$ (the reform year for synthetic control units is set equal to their respective country-reform's reform year). The $\alpha_{i}$ are unit (country-reform) fixed effects, $\beta_{k}$ are 
event time fixed effects, $\theta_{\text {Year( } i k)}$ are calendar year fixed effects, $\mathbb{1}[k=s]$ is an indicator for being in the $s$ th year relative to the reform, and Treated $i$ is an indicator for unit $i$ being a treated country-reform. The $\tau_{s}^{\text {Treated }}$ are the coefficients of interest, and represent effects relative to the omitted period $s=-1$. We also report average pre- and post-reform coefficients (with p-values calculated using the wild bootstrap method following Cameron, Gelbach, and Miller. 2008), and average post-reform coefficients calculated using the imputation methodology of Borusyak, Jaravel, and Spiess (2021). Standard errors are clustered at the country-reform level. Our research design controls for persistent differences between countries, e.g., in their institutional arrangement, by including country (country-reform) fixed effects, and for overall time trends through the inclusion of event-time and calendar-year fixed effects.

Results: Macroeconomic Outcomes Our macroeconomic outcome variables are drawn from the European Commission's AMECO Database and the World Inequality Database, and cover wage growth, the labor share, productivity growth, net capital formation, growth in GDP per capita, and the share of national income held by the bottom $90 \%$ (which we use as the most extensively available measure of income inequality) $5^{5}$ Event study results for these outcome variables are plotted in Panels (a)-(e) of Figure 3$]^{6}$ The results suggest that codetermination reforms have no noticeable effects on aggregate economic outcomes. Estimates are slightly imprecise, and pre-trends are at times unstable, but the post-reform coefficients for all outcome variables cluster around zero, and none are statistically significant.

Results: Industrial Relations In Figure 4, we also examine effects on industrial relations, drawing on data from the International Labour Organization, the World Economic Forum's Executive Opinion Survey, and the OECD/IAIS ICTWSS database (see Appendix Sections B.2. B.4). Panels (a) and (b) suggest that codetermination reforms either do not affect or slightly increase strike intensity and union density, not supporting the hypothesis that codetermination reforms reduce industrial conflict by increasing the friendliness of employeremployee relationships.7 Panel (c) displays the cross-sectional correlation between the strength of codetermination laws (as measured by the CBR Labor Regulation Index; Adams, Bishop,

${ }^{5}$ Due to data availability, our sample for the income inequality outcome differs slightly from our main sample; see Appendix Section B.6. We specify the wage/TFP/GDP variables as growth rates because specifications using levels are heavily affected by the accumulating effects of the sharp drop in growth rates between 2 years pre-reform and 1 year pre-reform that are observed in Figure 3 .

${ }^{6}$ In addition, Appendix Figure A.3 plots raw time series comparing our treated group to our synthetic control group; Appendix Figure A.4 checks the quality of our synthetic control fits by matching only on a training period $(k=-10$ to $k=-6)$ and plotting the quality of the resulting fit in an evaluation period $(k=-5$ to $k=-1)$; and Appendix Figures A.5. A.14 plot time series of each country-reform and its synthetic control unit.

${ }^{7}$ Note that our "union density" variable measures the fraction of a country's workers who belong to a union, which in European countries can diverge significantly from the fraction of workers covered by a collective bargaining agreement, due to the prevalence of sectoral bargaining (Schulten, 2016); we discuss collective bargaining separately in Sections 5 and 6 . 
and Deakin, 2016) and average responses to an item in the 2015 Executive Opinion Survey that asks managers to evaluate the "cooperativeness" of labor relations in their country on a 1-7 point scale, from "generally confrontational" to "generally cooperative." The results show a weak and statistically insignificant positive correlation between codetermination laws and cooperativeness (correlation coefficient 0.115, p-value 0.236); we therefore once again do not find strong evidence for the hypothesis that codetermination laws improve the quality of industrial relations. That said, the countries with the strongest codetermination systems-Germany, Austria, and the Nordic countries-have some of the most cooperative labor relations in the world according to this metric, ranking in the 94th percentile on average (for comparison, the U.S. is in the 79th percentile).

Conclusion and Caveats Overall, we find no evidence that codetermination reforms affect aggregate economic outcomes or industrial relations. Four important caveats apply. First, the estimates are somewhat imprecise, and synthetic control fits are sometimes imperfect (as visualized in Appendix Figures A.3 and A.4. Second, there are inherent limits on the credibility of cross-country difference-in-differences analyses, since sample sizes are small and the introduction of national legislation may be correlated with country-time-specific omitted variables. In particular, many of the reforms we study were motivated by periods of economic and political crisis, and were part of a package of other reforms (Jackson, 2005). Third, potential general-equilibrium effects may take longer to accumulate and materialize than our 10-year post-reform period. Fourth, most of the reforms studied are not wholesale introductions of codetermination but are codifications and expansions of codetermination rights in countries where a patchwork of informal or negotiated codetermination arrangements already existed (as detailed in Appendix Table A.1). Hence, our results may not speak to the impact of introducing codetermination in contexts like the U.S., where no codetermination arrangements exist, owing to the National Labor Relations Act; we return to this point in Section 6 . That said, we do study a pair of reforms that approximate wholesale introductions of codetermination (the 1978 Finnish reform and 1979 Dutch reform), and the impacts of these reforms do not appear larger (see Appendix Figures A.7and A.11).

Despite these caveats, these (to our knowledge) first estimates of the aggregate impacts of codetermination reforms provide at least suggestive evidence that the institution's generalequilibrium effects do not substantially exceed its small or nonexistent micro effects.

\section{What Explains Codetermination's Limited Effects?}

The empirical evidence we summarized and presented in Sections 244 suggests that codetermination has, on net, zero or slight positive effects on key worker and firm outcomes-in contrast 
to the strong predictions of both proponents and opponents of codetermination. In this section, we draw on qualitative evidence to build a comprehensive description of how codetermination operates in practice, a description which may help explain the institution's mild or nonexistent effects. For further discussion of the qualitative evidence and of contemporary lessons from the history of codetermination, see Jäger, Noy, and Schoefer (2021).

\subsection{Does Codetermination Boost Labor's Power?}

The first explanation we propose is that existing codetermination laws do not significantly boost workers' influence. This is firstly because, as we describe in this section, codetermination laws convey relatively little authority to workers; and secondly, as we describe in Section 5.2 . because European workers have high baseline levels of informal influence.

An important factor limiting the generalizability of such an explanation is the tremendous variation across countries in the amount of authority allocated to (especially shop-floor) worker representatives, and even within countries in the extent of successful worker participation in decision-making (Béthoux and Mias, 2021).

\subsubsection{Formal Authority}

As described in Section 1.2, codetermination laws rarely give workers much formal authority. Board-level representation laws usually grant workers a minority of seats, meaning workers can always be overruled by unanimous shareholders. Meanwhile, shop-floor worker representatives are usually limited to information and consultation rights, possibly with very restricted rights to judicial redress; rare exceptions include the co-decision-making powers (of varying scopes) allocated to German and Austrian works councils, and to Swedish and Norwegian shop-floor union representatives.

\subsubsection{Real Authority}

Our synthesis of a number of case studies, interviews, and surveys suggests four conclusions about the real authority conveyed by codetermination laws.

Moderate Influence on Working Conditions Case studies suggest that worker representatives focus most of their attention on improving working conditions. For example, Swedish shop-floor representatives describe mostly participating in decisions about working hours, health and safety, and workplace amenities, and dealing with problems of sexual harassment and mistreatment of workers by managers (Wheeler, 2002). In board meetings, Swedish worker representatives are the most active during discussions of working conditions (Levinson, 2000). Workers and managers agree that worker representatives are at their most influential 
when participating in decisions about working conditions (Levinson, 2000; Harju, Jäger, and Schoefer, 2021).

Yet, the exact extent of this influence over working conditions remains unclear. Only 30\% of Finnish board-level representatives claim an ability to improve working conditions (Harju, Jäger, and Schoefer, 2021). By contrast, 55\% of Danish board-level representatives claim a "reasonable" or "high" amount of influence in general (Rose, 2008). Meanwhile, just under $50 \%$ of managers in the 2019 European Company Survey claim that worker representatives wield a "moderate" or "great" amount of influence over decisions about working conditions in their firm (see Panel (b) of Figure 5, which we will discuss further in Section 5.2. Meanwhile, a striking $96 \%$ of Swedish Managing Directors say that shop-floor representatives exert "large" or "very large" influence over decisions in this area, perhaps reflecting the particular strength of Swedish shop-floor union representation (Levinson, 2000). The ability of worker representatives to improve working conditions may explain the evidence for some positive effects of codetermination on subjective job satisfaction.

Small Influence on Layoffs Worker representatives generally lack influence over layoff decisions. In accordance with information and consultation requirements, they describe being extensively consulted about planned layoffs, and a minority even report successfully negotiating the prevention of layoffs (Gold, Kluge, and Conchon, 2010). However, worker representatives state that managers often override their objections to planned layoffs (Wheeler. 2002; Gold, Kluge, and Conchon, 2010). Managers in the 2019 European Company Survey mostly agree that worker representatives do not influence layoff decisions (see Panel (a) of Appendix Figure A.15.

Anecdotal evidence suggests that worker representatives are more able to prevent layoffs during economic crises, perhaps by negotiating wage and hour cuts, as described by Rehder (2003) for German firms. Additionally, the prospect of going through costly consultation and negotiation requirements may deter dismissals in the first place. These mechanisms may explain the small reductions in involuntary separations described in Section 2.

Small Influence on Wage Setting Similarly, worker representatives describe wielding at best small influence over wage setting. Just $15 \%$ of Finnish board-level representatives believe they can affect wage levels (Harju, Jäger, and Schoefer, 2021), and only 35\% of managers in the 2019 European Company Survey claim that worker representatives wield a "moderate" or "great" amount of influence over payment schemes (a category that includes decisions about performance pay or piece rates as well as overall wage levels; see Panel (d) of Appendix Figure A.15). This lack of influence on wage setting may stem from the dominance of sectoral bargaining in these countries, as we describe in Section 5.3. Overall, these patterns are consistent with the at best small positive wage impacts summarized in Section 2 . 
No Influence on Corporate Strategy There is nearly unanimous agreement that even on boards, worker representatives have no influence on broad strategic decisions. Fewer than $5 \%$ of Finnish board-level representatives believe they can affect strategic decisions (Harju, Jäger, and Schoefer, 2021), and Swedish managing directors describe board-level worker representatives as completely inactive in strategic discussions (Levinson, 2000). The general perception among worker representatives is that strategic decisions are made out of their view, and presented to them once management's mind is already made up (Wheeler, 2002; Gold, Kluge, and Conchon, 2010). This self-professed near-complete lack of influence on strategic decisions highlights the lack of power conveyed by arrangements like minority board-level representation, and may help explain the absence of negative empirical effects on firm performance.

\subsubsection{Conclusion}

The available evidence paints a picture of codetermination as an institution that grants workers some limited control, mostly over their immediate working conditions-providing a natural explanation of the institution's limited empirical effects on major economic outcomes like wages or investment. This "limited power" explanation also accommodates the possibility that stronger codetermination arrangements, such as the more powerful works councils in Germany, possibly have larger impacts, as discussed in Sections 2 and 3.

\subsection{Quality of Industrial and Workforce-Management Relations}

The second explanation we explore is that strong cultures of informal worker participation and worker-management cooperation in Europe may mean that formal codetermination requirements barely shift the needle.

Worker Participation Interviews of managers from the European Company Survey provide evidence for a robust culture of informal worker participation, such that managers in establishments with and without formal codetermination report similar degrees of worker involvement. Figure 5 illustrates this pattern across both the 2013 and 2019 waves. In the 2013 survey, just under $50 \%$ of managers in firms without formal worker representation reported that workers were directly involved in the firm's most important recent decision, compared to $60 \%$ of managers in firms with worker representation who said that worker representatives were involved in the most important recent decision (Panel (a) of Figure 5). In the 2019 survey, about $55 \%$ of managers in establishments without worker representation said that workers directly exerted a "moderate" or "great" amount of influence over decisions about working conditions, compared to $45 \%$ of managers in firms with worker representation who said the same thing about worker representatives (Panel (b) of Figure 5). Panel (c) of Figure 5 shows that 
larger European firms (which are more likely to be subject to codetermination requirements) do not involve workers in decision-making more frequently than smaller firms; rather, the nature of the worker involvement simply shifts, from informal direct involvement in smaller firms to formal representation in larger firms. Panel (d) of Figure 5 shows that, in simple cross-country regressions, the strength of a country's codetermination laws is uncorrelated with the percentage of firms in that country who report some kind of worker involvement in decision-making. Overall, this evidence paints a picture of widespread informal worker participation irrespective of formal codetermination. We caution that this survey evidence is far from conclusive- the quality of worker involvement may differ between codetermined and non-codetermined firms, for example if managers in codetermined firms have a higher standard for what constitutes "worker involvement in a decision."

Harmonious Labor-Management Relations The relative warmth of contemporary labormanagement relations in Europe may also help explain codetermination's limited impact. Most of the evidence cited in Sections $2-3$ was from studies of German or Nordic codetermination; as we noted in Section 4 , while codetermination laws in general are not strongly associated with cooperative industrial relations, Germany and the Nordic countries in particular have some of the most cooperative industrial relations in the world. In such a cooperative context, worker representatives may exercise their powers in less disruptive ways and agree more with employers, consistent with interview evidence that board-level representatives generally accede to the plans of managers and directors due to believing their interests are broadly aligned with those of the firm (Gold, Kluge, and Conchon, 2010; Jäger, Noy, and Schoefer, 2021). We do not mean to suggest that German and Nordic industrial relations have always been harmonious-codetermination reforms in these countries were typically preceded by periods of intense industrial conflict-but the contemporary peacefulness of labor-management relations may explain the small effects estimated by studies exploiting modern variation in codetermination.

Impacts of Codetermination Laws on Industrial Relations Perhaps both factors outlined above are consequences of codetermination laws-shared governance requirements could normalize and spread cultures of worker participation and make worker-management relationships less adversarial, as we mentioned in Section 4 . However, our country-level empirical tests in Section 4 failed to find evidence that codetermination laws improve the quality of industrial relations. We therefore advance an alternative hypothesis: that in Germany and the Nordic countries, codetermination reforms, the formation of firm-level cultures of worker participation, and the development of cooperative labor-management relations were all caused by pre-existing traditions of worker mobilization and bilateral negotiation. For example, Denmark, Norway, and Sweden have histories of large-scale union-employer bargaining dating 
back to the early 1900s; codetermination reforms resulted from conscious attempts to channel this worker mobilization into more cooperative forms (as in, e.g., the Swedish Saltsjöbaden Agreement), and it seems plausible that employers' willingness to involve workers in informal cooperative discussions has been partly caused by the background pressure exerted on firms by powerful national unions (Bjorheim, 1974: Knudsen, 2006: Sippola, 2012, Votinius, 2012). That said, it is also possible that codetermination may lead to more harmonious labor relations over longer horizons, consistent with, e.g., Germany's transition from at times violent industrial conflict to harmonious labor relations over the course of the 20th Century (see also Thelen, 1991).

\subsection{Other Labor Market Institutions}

Compared to liberal market economies like the U.S., the German and Nordic labor marketsfrom which most of the evidence we reviewed stemmed-feature a range of other powerful pro-worker institutions: centralized collective bargaining, powerful unions, and extensive labor market regulations. We visualize institutional differences between codetermined and comparable non-codetermined countries in Figure 2, drawing on data from the OECD/IAIS ICTWSS database (Visser, 2021) and the CBR Labor Regulation Index (Adams, Bishop, and Deakin, 2016). We now ask whether the presence of these institutions may leave little scope for codetermination to have an impact.

Centralized Collective Bargaining As Panels (a) and (e) of Figure 2 shows, countries with codetermination laws tend to have more centralized systems of collective bargaining, and much higher collective bargaining coverage, than comparable countries without codetermination. In the U.S., collective bargaining proceeds at the company level and coverage is spotty (Compa, 2014). By contrast, in Germany and the Nordic countries, unions and employer associations negotiate industry-wide collective bargaining agreements that cover large swathes of the workforce and impose wage floors and minimum requirements on working conditions. Employers can deviate upwards (and sometimes even downwards) from these floors, and descriptive studies confirm they retain plenty of discretion (Uusitalo and Vartiainen, 2009; Card, Heining, and Kline, 2013). Nevertheless, these collective bargaining agreements may compress wages and working conditions and thereby dampen the effects of codetermination. However, Jäger, Schoefer, and Heining (2021) do not find significant wage effects of board-level representation even in German industries with lower collective bargaining coverage. Similarly, a large body of studies have not found that shop-floor representation has larger wage effects in establishments not covered by a collective bargaining agreement (Jirjahn, 2017). Thus, the existence of centralized systems of collective bargaining seems unlikely to explain the limited (wage) effects of codetermination. 
Union Representation Panel (b) of Figure 2 shows that countries with codetermination laws have rates of union membership that are on average 20 percentage points higher than comparable countries without codetermination. High union density could help explain codetermination's limited impacts because unions might already satisfy the function of advocating for workers and counterbalancing the institutional power of employers. However, the fact that unions have historically expended a great deal of political effort advocating for codetermination requirements (Bjorheim, 1974; Knudsen, 2006; Votinius, 2012; Silvia, 2013; :McGaughey, 2016) suggests that they view codetermination as complementary to their activities rather than superfluous. We return to this point in Section 6 .

Labor Market Regulation The German and Nordic labor markets are tightly regulated by global standards, especially when compared to countries like the U.S. Panel (c) of Figure 2 shows that, on average, countries with codetermination sit at the 70th percentile worldwide in terms of labor market regulation, while comparable countries without codetermination sit at the 25th percentile. German and Nordic labor market regulations-covering everything from flexible hours to overtime to leave entitlements to restrictions on dismissal-may leave little scope for worker representatives to negotiate improvements in working conditions.

\subsection{Conclusion}

The limited impacts of European codetermination may reflect an inherent lack of power conveyed by existing arrangements, or the presence of institutional surrogates; future research could shed light on which of these potential explanations is most important in practice. Below, we discuss what these explanations might imply for the prospects of recent codetermination proposals in the United States.

\section{What Would Codetermination Do in the United States?}

The past four years have seen a surge of interest in codetermination among progressive American policy-makers, commentators, and academics. Shared governance laws have been viewed as a potential antidote for a perceived decline in the power of workers relative to shareholders and managers within corporations (see, e.g., Liebman, 2017; Greenwald, Lettau, and Ludvigson, 2018; Hockett et al., 2018; Yglesias, 2018; Stansbury and Summers, 2020; Strine Jr., Kovvali, and Williams, 2021). This perceived deterioration of worker power has motivated policy proposals aimed at expanding or strengthening worker representation, either by reinvigorating American unions or by introducing shared governance arrangements modeled after European codetermination. 


\subsection{Recent Codetermination Proposals}

Board-level codetermination provisions are a key element of two pieces of legislation introduced by Democratic senators in 2018 - the Reward Work Act, which would require all listed companies in the U.S. to adopt one-third board-level worker representation, and the Accountable Capitalism Act, which would require U.S. corporations with more than $\$ 1$ billion in tax receipts to adopt $40 \%$ board-level worker representation. In addition, informal proposals for shop-floor codetermination reforms have circulated recently among American commentators (Liebman, 2017: Silvia, 2018; Cass, 2020; Silvia, 2020; Strine Jr., Kovvali, and Williams, 2021).

Recent codetermination proposals are not being advanced in isolation: they are part of a broader legislative agenda intended to increase the influence of workers. During the 2020 Democratic primaries, several major candidates (including Joe Biden, Pete Buttigieg, Elizabeth Warren, and Bernie Sanders) announced intentions to explore the introduction of sectoral collective bargaining systems (Vox, 10/29/2019); in 2021, the PRO Act, which would significantly strengthen American unions, passed through the Democrat-controlled House of Representatives (NPR, 03/09/2021). The Nordic context shows that expansions of firm-level union representation can even be combined with codetermination reforms, through the allocation of co-decision-making rights to union representatives.

Advocates of recent codetermination proposals face two practical hurdles. First, any attempt at federal or state-level shop-floor codetermination legislation would force a much broader conversation about amending Section 8(a)2 of the National Labor Relations Act, which currently stifles any local experimentation with more cooperative forms of shop-floor representation (even if both workers and the employers would support such experimentation; Liebman, 2017). The 1994 Dunlop Report, commissioned by the Clinton administration, recommended a partial repeal of Section 8(a)2 in the context of its finding that American workers would appreciate more cooperative avenues for voice in their workplaces (Addison, Schnabel, and Wagner, 2001; Befort, 2004).

Second, as several commentators emphasize, there is a long list of important practical questions concerning how codetermination would be implemented in the U.S. (Liebman, 2017; Dammann and Eidenmueller, 2021; Strine Jr., Kovvali, and Williams, 2021). The European solutions to these practical problems draw indispensably on institutional features of European labor markets, including widespread union representation and broader frameworks of social partnership, that are currently comparatively absent in the U.S. We now discuss what the interactions between European codetermination and other European labor market institutions might imply for a potential American version of codetermination. 


\subsection{What Would U.S. Codetermination Look Like? What Would it Do?}

Union Representation The fact that union representation in codetermined European countries is much more extensive than in the U.S. has several practical implications, as Strine Jr., Kovvali, and Williams (2021) emphasize. European codetermination laws typically set up shared governance procedures that explicitly refer to unions at a number of stages (ETUI, 2020). First, when legislation prescribes a right to codetermination that workers can voluntarily take up, company-level union representatives are usually responsible for initiating the proceedings that establish codetermination. Second, elections of worker representatives are usually organized by unions. Third, union representatives form a ready pool of candidates. There is little precedent for how codetermination might be implemented in the U.S., where many workplaces lack union representatives or alternative foci of employee organization.

In addition, low union density in the U.S. means that American codetermination may have either stronger or even weaker impacts than European codetermination, as we described in Section 5.3. If the worker voice institutions are substitutes, codetermination may have a larger marginal effect in the U.S. This view is hard to square with the history of vigorous union advocacy for codetermination rights. By contrast, union representation may complement codetermination by allowing workers to speak with a unified voice and take full advantage of co-decision-making rights (Doellgast, Holtgrewe, and Deery, 2009; Liebman, 2017). Consistent with this view, scattered historical experiments with worker participation in the U.S. inevitably died out when management soured on the arrangements and there was no push-back from unions (Hammer, Currall, and Stern, 1991), and German works councils in industries where union influence is retreating have struggled to maintain their influence (Müller-Jentsch, 1992). Moreover, unions provide an outlet for workers' adversarial demands or grievances, leaving board-level or shop-floor worker representatives free to cooperate peacefully with employers (Pfeifer, 2010).

Sectoral Bargaining Codetermined European countries have collective bargaining systems that operate primarily at the industry level, while bargaining in the U.S. happens at the company level (if at all). As we noted in Section 5.3, there is no evidence that sectoral bargaining curbs potential wage effects of codetermination. However, sectoral bargaining may complement codetermination-for example, by outsourcing adversarial bargaining to the industry level, sectoral bargaining may make firm-level labor relations more friendly and conducive to shared governance. American managers are often encouraged to fear and obstruct worker organization (Lafer and Loustaunau, 2020), perhaps partly because the costs of unionization are so salient to employers when bargaining happens at the company level. 
Labor Regulations Certain kinds of labor market regulations prominent in European settings may complement shared governance requirements. For example, employment protection legislation may reduce turnover and hence raise trust and enable greater investment in cooperative worker-employer relationships, similar to the model in MacLeod and Nakavachara (2007). In the American environment of at-will employment, employers and workers may struggle to build trust.

Quality of Industrial Relations A long-standing hypothesis is that the effects of increasing worker power hinge on the pre-existing quality of labor-management relationships (Freeman and Medoff, 1984; Kochan and Kimball, 2019). In a hostile atmosphere, boosting workers' authority might simply intensify negative-sum conflict, consistent with negative effects of unionization on firm performance in the United States, at least on average (Lee and Mas, 2012; Frandsen, forthcoming). As we mentioned in Section 4 , managers indeed consider labor relations in Germany and the Nordic countries more harmonious and cooperative than in the U.S. In addition, foreign employers operating in Germany have much less cooperative relationships with their works councils than domestic employers do (Dill and Jirjahn, 2017), and the positive association between works councils and productivity appears to materialize only among domestic employers (Jirjahn and Mueller, 2014). These patterns suggest codetermination may have different impacts in the U.S., at least in the short term.

Conclusion Given the deep institutional differences, it is hard to extrapolate from the existing European evidence to the likely effects of American codetermination proposals. One conclusion that is clear from this discussion is that codetermination is not a standalone institution. Rather, it is part of a broader institutional and cultural package whose other elements complement codetermination and supply its practical infrastructure. The recent American policy discourse has seen several proposals to introduce other elements of the European package, including stronger union representation and sectoral collective bargaining.

\section{Overall Conclusions}

The evidence indicates that the European model of codetermination is neither a panacea for all the problems faced by 21st-century workers, nor a destructive institution that appears obviously inferior to shareholder control. Rather, it is a moderate institution with nonexistent or small positive net effects. Board-level and shop-floor worker representation cause at most small increases in wages, possibly lead to slight increases in job security and satisfaction, and have largely zero or small positive effects on firm performance. These limited effects may reflect limited power conveyed by existing codetermination arrangements, cultures of informal 
worker-management cooperation, or the influence of other pro-worker institutions. If cultural or institutional features of European labor markets are key to explaining codetermination's limited impacts, codetermination might have more noticeable effects if introduced in the U.S. There are also important practical complementarities between codetermination and other European labor market institutions.

There are a number of promising directions for future work on codetermination. First, it remains an open question whether codetermination arrangements that convey greater power to workers, such as parity board-level representation in Germany, have more substantial positive or negative impacts (Svejnar, 1981). Second, beyond a few correlational tests or heterogeneity analyses, there is a paucity of evidence speaking to the interaction of codetermination with other labor market institutions. Third, we lack estimates of the effects of shared governance on intangible outcomes like worker alienation or feelings of domination or insecurity. Fourth, while we provide novel country-level event study analyses, a promising avenue for work on aggregate, general-equilibrium effects of codetermination may be to leverage treatment variation at the level of industries or local labor markets.

We close by emphasizing that our paper focuses solely on the economic consequences of codetermination. Addison(2009) observes that, perhaps surprisingly, economic considerations have not historically been at the forefront of the German public debate about codetermination. Rather, the conversation has been dominated by non-consequentialist justifications of codetermination rooted in principles of economic democracy and the dignity of work (Budd, 2004). Echoing this view of codetermination, in 2001, the German government dismissed concerns that its drafted extension of the Works Council Act would be costly to businesses by declaring:

Democracy is not cost neutral. This principle also applies to democracy at the workplace and to the resulting system of establishment-level codetermination. (As quoted in Addison, 2009, p.22; see Bundestag, 2001)

The idea that democratic political principles should be extended to the realm of private business has recently regained popularity in analytic political philosophy (Anderson, 2017; Frega, Herzog, and Neuhäuser, 2019; Walters, 2021). Elizabeth Anderson writes:

Government is everywhere, not just in the form of the state, but even more pervasively in the workplace. [...] The vast majority [of workers] are subject to private, authoritarian government, not through their own choice, but through laws that have handed nearly all authority to their employers. (Anderson, 2017, p.70-71)

She adds that, once one recognizes this fact, one is forced to conclude that:

[...] There is no adequate substitute for recognizing workers' voice in their government. (Anderson, 2017, p.69) 
Quasi-experimental studies of the economic impacts of codetermination do not directly speak to these important non-consequentialist questions. However, the conclusion suggested by the evidence- that codetermination in its current form has limited consequences for core economic outcomes-may shift the focus of the debate to such non-consequentialist arguments. 


\section{References}

Abadie, Alberto, Alexis Diamond, and Jens Hainmueller. 2011. "SYNTH: Stata Module to Implement Synthetic Control Methods for Comparative Case Studies." Statistical Software Components .

Adam, Julian. 2019. “Voluntary Quits: Do Works Councils Matter? An Analysis of the Reform of the German Works Constitution Act 2001." Jahrbücher für Nationalökonomie und Statistik 239 (1).

Adams, Zoe, Louise Bishop, and Simon Deakin. 2016. "CBR Labor Regulation Index (Dataset of 117 Countries)." Centre for Business Research, University of Cambridge .

Addison, John. 2009. The Economics of Codetermination: Lessons from the German Experience. Palgrave Macmillan.

Addison, John, Thorsten Schank, Claus Schnabel, and Joachim Wagner. 2007. “Do Works Councils Inhibit Investment?" ILR Review 60 (2):187-203.

Addison, John, Claus Schnabel, and Joachim Wagner. 1997. "On the Determinants of Mandatory Works Councils in Germany." Industrial Relations 36 (4):419-445.

- 2001. "Works Councils in Germany: Their Effects on Establishment Performance." Oxford Economics Papers 53 (4):659-694.

- 2004. "The Course of Research into the Economic Consequences of German Works Councils." British Journal of Industrial Relations 42 (2):255-281.

Anderson, Elizabeth. 2017. Private Government: How Employers Rule Our Lives (and Why We Don't Talk about It). Princeton University Press.

Arnold, Daniel, Tobias Brändle, and Laszlo Goerke. 2018. "Sickness Absence and Works Councils: Evidence from German Individual and Linked Employer-Employee Data." Industrial Relations 57 (2):260-295.

Aumayr, Christine, Demetriades Stavroula, David Foden, Vera Scepanovics, and Felix Wolf. 2011. "Employee Representation at Establishment Level in Europe." Eurofound Report .

Baums, Theodor and Bernd Frick. 1998. "Co-determination in Germany: the Impact of Court Decisions on the Market Value of Firms." Economic Analysis London 1:143-162.

Befort, Stephen. 2004. "A New Voice for the Workplace: A Proposal for an American Works Councils Act." Missouri Law Review 69 (3):607-652. 
Bermig, Andreas and Bernd Frick. 2010. "Board Size, Board Composition, and Firm Performance: Empirical Evidence from Germany." Working Paper .

Béthoux, Elodie and Arnaud Mias. 2021. "How Does State-Led Decentralization Affect Workplace Employment Relations? The French Case in a Comparative Perspective." European Journal of Industrial Relations 27 (1):5-21.

Bjorheim, Lars. 1974. "The Development of Industrial Democracy in Norway." Conference Paper.

Blandhol, Christine, Magne Mogstad, Peter Nilsson, and Ola Vestad. 2020. “Do Employees Benefit from Worker Representation on Corporate Boards?" NBER Working Paper.

Borusyak, Kirill, Xavier Jaravel, and Jann Spiess. 2021. "Revisiting Event Study Designs: Robust and Efficient Estimation." Working Paper .

Budd, John. 2004. Employment with a Human Face: Balancing Efficiency, Equity, and Voice. Cornell University Press.

Bundestag. 2001. “Begründung zum Entwurf eines Gesetzes zur Reform des Betriebsverfassungsgesetzes (Translation: "Justification for the draft law to reform the Works Constitution Act")." .

Burdín, Gabriel and Andrés Dean. 2009. "New Evidence on Wages and Employment in Worker Cooperatives Compared with Capitalist Firms." Journal of Comparative Economics $37(4): 517-533$.

—. 2012. "Revisiting the Objectives of Worker-Managed Firms: An Empirical Assessment." Economic Systems 36 (1):158-171.

Cameron, Colin, Jonah Gelbach, and Douglas Miller. 2008. "Bootstrap-Based Improvements for Inference with Clustered Errors." The Review of Economics and Statistics 90 (3):414-427.

Card, David, Jörg Heining, and Patrick Kline. 2013. "Workplace Heterogeneity and the Rise of West German Wage Inequality." Quarterly Journal of Economics 128 (3):967-1015.

Carmichael, Lorne. 1983. "Firm-Specific Human Capital and Promotion Ladders." The Bell Journal of Economics :251-258.

Cass, Oren. 2020. "Constraining the Corporation." URL https://americancompass.org/ essays/constraining-the-corporation/. 
Compa, Lance. 2014. "An Overview of Collective Bargaining in the United States." In El derecho a la negociación colectiva: Monografías de temas laborales, edited by Juan Gorelli Hernández. Seville: Consejo Andaluz de Relaciones Laborales, 91-98.

Conchon, Aline. 2011. "Board-Level Employee Representation Rights in Europe: Facts and Trends." European Trade Union Institute Report 121.

Dammann, Jens and Horst Eidenmueller. 2021. "Codetermination: A Poor Fit for U.S. Corporations." Columbia Business Law Review 2020 (3).

Dill, Verena and Uwe Jirjahn. 2017. "Foreign Owners and the Quality of Industrial Relations in Germany." Economic and Industrial Democracy 38 (1):5-25.

Doellgast, Virginia, Ursula Holtgrewe, and Stephen Deery. 2009. “The Effects of National Institutions and Collective Bargaining Arrangements on Job Quality in Front-Line Service Workplaces." ILR Review 62 (4):489-509.

ETUI. 2020. “National Industrial Relations." URL https://www.worker-participation. eu/ National-Industrial-Relations/Countries.

Frandsen, Brigham. forthcoming. "The Surprising Impacts of Unionization: Evidence from Matched Employer-Employee Data." Journal of Labor Economics .

Freeman, Richard and Edward Lazear. 1995. "An Economic Analysis of Works Councils." In Works Councils: Consultation, Representation, Cooperation in Industrial Relations, edited by Joel Rogers and Wolfgang Streeck. NBER Comparative Labor Markets Series.

Freeman, Richard and James Medoff. 1984. What Do Unions Do? Basic Books.

Frega, Roberto, Lisa Herzog, and Christian Neuhäuser. 2019. "Workplace Democracy-The Recent Debate." Philosophy Compass 14 (4).

Frege, Carola and John Godard. 2014. "Varieties of Capitalism and Job Quality: The Attainment of Civic Principles at Work in the United States and Germany." American Sociological Review 79 (5).

Friedman, Milton. 1970. "The Social Responsibility of Business is to Increase its Profits." The New York Times Magazine .

Furubotn, Eirik. 1988. "Codetermination and the Modern Theory of the Firm: A PropertyRights Analysis." The Journal of Business 61 (2):165-181. 
Garicano, Luis, Claire Lelarge, and John Van Reenen. 2016. "Firm Size Distortions and the Productivity Distribution: Evidence from France." American Economic Review 106 (11):3439_ 79.

Gold, Michael, Norbert Kluge, and Aline Conchon. 2010. 'In the Union and on the Board': Experiences of Board-Level Employee Representatives across Europe. European Trade Union Institute.

Gold, Michael and Jeremy Waddington. 2019. "Board-Level Employee Representation in Europe: State of Play." European Journal of Industrial Relations 25 (3):205-218.

Gorton, Gary and Frank Schmid. 2004. "Capital, Labor, and the Firm: A Study of German Codetermination." Journal of the European Economic Association 2 (5):863-905.

Gralla, Rafael and Kornelius Kraft. 2018. "Separating Introduction Effects from Selectivity Effects: The Differences in Employment Patterns of Codetermined Firms." Labour 32 (1):93111.

Greenwald, Daniel, Martin Lettau, and Sydney Ludvigson. 2018. "How the Wealth Was Won: Factor Shares as Market Fundamentals." NBER Working Paper .

Gregoric, Aleksandra and Marc Steffen Rapp. 2019. "Board-Level Employee Representation (BLER) and Firms' Responses to Crisis." Industrial Relations 58 (3):376-422.

Gumbrell-McCormick, Rebecca and Richard Hyman. 2013. Trade Unions in Western Europe: Hard Times, Hard Choices. Oxford University Press.

Hammer, Tove, Steven Currall, and Robert Stern. 1991. "Worker Representation on Boards of Directors: A Study of Competing Roles." ILR Review 44 (4):661-680.

Hammond, Samuel. 2018. "Elizabeth Warren's Corporate Catastrophe." URL https://www.nationalreview.com/2018/08/elizabeth-warren-accountablecapitalism-act-terrible-idea/.

Hansmann, Henry and Reinier Kraakman. 2000. "The End of History for Corporate Law." The Georgetown Law Journal 89:439-468.

Harju, Jarkko, Simon Jäger, and Benjamin Schoefer. 2021. "Voice at Work." NBER Working Paper.

Hayden, Grant M. and Matthew T. Bodie. 2021. "Codetermination in Theory and Practice." Florida Law Review 73 (2):1-42. 
Hirsch, Boris and Steffen Mueller. 2020. "Firm Wage Premia, Industrial Relations, and Wage Sharing in Germany." ILR Review 73 (5):1119-1146.

Hirsch, Boris, Thorsten Schank, and Claus Schnabel. 2009. "Works Councils and Separations: Voice, Monopoly, and Insurance Effects." IZA Discussion Paper .

Hirschman, Albert. 1970. Exit, Voice, and Loyalty. Cambridge, Mass.: Harvard Univ. Press.

Hockett, Robert, Kaushik Basu, Dan Alpert, Jennifer Taub, Robert Frank, Saule Omarova, Gautam Mukunda, Fadhel Kaboub, K. Sabeel Rahman, Pavlina Tcherneva, Stephen Lubben, Thomas Herndon, Jeff Madrick, and William Lazonick. 2018. "Letter to Elizabeth Warren in Support of the Accountable Capitalism Act." .

Hörisch, Felix. 2012. "The Macro-Economic Effect of Codetermination on Income Equality." SSRN Working Paper 2187264.

Jackson, Gregory. 2005. "Employee Representation in the Board Compared: A Fuzzy Sets Analysis of Corporate Governance, Unionism and Political Institutions." Industrielle Beziehungen 12 (3):1-28.

Jäger, Simon, Shakked Noy, and Benjamin Schoefer. 2021. "Codetermination and Power in the Workplace." Working Paper .

Jäger, Simon, Benjamin Schoefer, and Jörg Heining. 2021. "Labor in the Boardroom." Quarterly Journal of Economics 136 (2):669-725.

Jensen, Michael and William Meckling. 1979. "Rights and Production Functions: An Application to Labor-Managed Firms and Codetermination." The Journal of Business 52 (4):469-506.

Jirjahn, Uwe. 2010. "Works Councils and Employment Growth in German Establishments." Cambridge Journal of Economics 34 (3):475-500.

—. 2017. "Works Councils and Collective Bargaining in Germany: A Simple Theoretical Extension to Reconcile Conflicting Empirical Findings." Journal of Institutional and Theoretical Economics 173 (2):322-346.

Jirjahn, Uwe and Steffen Mueller. 2014. "Non-Union Worker Representation, Foreign Owners, and the Performance of Establishments." Economic and Industrial Democracy 66 (1):140-163.

Jirjahn, Uwe and Stephen Smith. 2018. "Nonunion Employee Representation: Theory and the German Experience With Mandated Works Councils." Annals of Public and Cooperative Economics 89 (1):201-233. 
Keskinen, Maija. 2017. “Workplace Cooperation and Firm Performance - Evidence from Finland." Aalto University Master's Thesis .

Kim, Han, Ernst Maug, and Christoph Schneider. 2019. "Labor Representation in Governance as an Insurance Mechanism." Review of Finance 22 (4):1251-1289.

Knudsen, Herman. 2006. "Workplace Representation in Denmark - Structure and Role." HIVA-EZA Conference Paper .

Kochan, Thomas and William Kimball. 2019. “Unions, Worker Voice, and Management Practices: Implications for a High-Productivity, High-Wage Economy." RSF: The Russell Sage Foundation Journal of the Social Sciences 5 (5):88-108.

Lafer, Gordon and Lola Loustaunau. 2020. "Fear at Work." URL https://www.epi.org/ publication/fear-at-work-how-employers-scare-workers-out-of-unionizing/.

Lazear, Edward. 1979. "Why is there Mandatory Retirement?" Journal of Political Economy 87 (6):1261-1284.

Lee, David and Alexandre Mas. 2012. "Long-Run Impacts of Unions on Firms: New Evidence From Financial Markets, 1961-1999.” Quarterly Journal of Economics 127 (1):333-378.

Levine, David and Laura D'Andrea Tyson. 1990. Paying for Productivity, chap. Participation, Productivity, and the Firm's Environment. Brookings Institution.

Levinson, Klas. 2000. "Codetermination in Sweden: Myth and Reality." Economic and Industrial Democracy 21:457-473.

Liebman, Wilma. 2017. “Does Federal Labor Law Preemption Doctrine Allow Experiments With Social Dialogue?" Harvard Law and Policy Review .

Lin, Chen, Thomas Schmid, and Yuhai Xuan. 2018. "Employee Representation and Financial Leverage." Journal of Financial Economics 127 (2):303-324.

Lindbeck, Assar and Dennis Snower. 1989. The Insider-Outsider Theory of Employment and Unemployment. MIT Press Books.

MacLeod, W. Bentley and Voraprapa Nakavachara. 2007. “Can Wrongful Discharge Law Enhance Employment?" The Economic Journal 117 (521):F218-F278.

Malcomson, James. 1983. "Trade Unions and Economic Efficiency." The Economic Journal 93:51-65. 
McCrary, Justin. 2008. "Manipulation of the Running Variable in the Regression Discontinuity Design: A Density Test." Journal of Econometrics 142 (2):698-714.

McGaughey, Ewan. 2016. "The Codetermination Bargains: The History of German Corporate and Labor Law." Columbia Journal of European Law 23 (1):1-43.

Mueller, Steffen. 2012. "Works Councils and Establishment Productivity." ILR Review 65 (4):880898.

Mueller, Steffen and Georg Neuschaeffer. 2020. "Worker Participation in Decision-Making, Worker Sorting, and Firm Performance." IWH Discussion Paper .

Mueller, Steffen and Jens Stegmaier. 2017. "The Dynamic Effects of Works Councils on Labour Productivity: First Evidence from Panel Data." British Journal of Industrial Relations 55 (2):372-395.

Müller-Jentsch, Walther. 1992. Works Councils: Consultation, Representation, and Cooperation in Industrial Relations, chap. Germany: From Collective Voice to Co-Management. University of Chicago Press.

Page, Rebecca. 2018. “Codetermination in Germany_A Beginner's Guide." Arbeitspapier, Hans-Böckler-Stiftung .

Paster, Thomas. 2012. "Do German Employers Support Board-Level Codetermination? The Paradox of Individual Support and Collective Opposition." Socio-Economic Review 10 (3):471495.

Pfeifer, Christian. 2010. "Works Councils, Union Bargaining and Quits in German Firms." Economic and Industrial Democracy 32 (2):243-260.

Redeker, Nils. 2019. The Politics of Stashing Wealth: The Demise of Labor Power and the Global Rise of Corporate Savings. Working Paper.

Rehder, Britta. 2003. Betriebliche Bündnisse für Arbeit in Deutschland: Mitbestimmung und Flächentarif im Wandel. Campus Verlag.

Rose, Caspar. 2008. "The Challenges of Employee-Appointed Board Members for Corporate Governance: The Danish Evidence." European Business Organization Law Review 9 (2):215-235.

Schnabel, Claus. 2020. "Betriebliche Mitbestimmung in Deutschland: Verbreitung, Auswirkungen und Implikationen (Translation: "Workplace participation in Germany: distribution, effects and implications")." Perspektiven der Wirtschaftspolitik 21 (4). 
Schulten, Thorsten. 2016. "The Meaning of Extension for the Stability of Collective Bargaining in Europe." ETUI Policy Brief .

Shackford, Scott. 2018. "Elizabeth Warren Plans to Destroy Capitalism By Pretending to 'Save' It." URL https://reason.com/2018/08/15/elizabeth-warren-plans-todestroy-capita/.

Silvia, Stephen. 2013. Holding the Shop Together: German Industrial Relations in the Postwar Era. Cornell University Press.

— 2018. "The United Auto Workers' Attempts to Unionize Volkswagen Chattanooga." ILR Review 71 (3):600-624.

—. 2020. "The UAW Attempts to Organize Volkswagen Chattanooga: The Sequel." Working Paper.

Sippola, Markku. 2012. "Local Bargaining and Codetermination: Finnish Experience in Comparative Perspective." European Journal of Industrial Relations 18 (1):53-69.

Smith, Stephen. 1991. "On the Economic Rationale for Codetermination Law." Journal of Economic Behavior and Organization 16 (3):261-281.

Stansbury, Anna and Lawrence Summers. 2020. "The Declining Worker Power Hypothesis: An Explanation for the Recent Evolution of the American Economy." NBER Working Paper .

Stettes, Oliver. 2007. “Die Arbeitnehmermitbestimmung im Aufsichtsrat: Ergebnisse einer Unternehmensbefragung." IW-Trends-Vierteljahresschrift zur empirischen Wirtschaftsforschung 34 (1):17-30.

Strine Jr., Leo. 2002. “The Social Responsibility of Boards of Directors and Stockholders in Charge of Control Transactions: Is There Any "There" There?" Southern California Law Review 75 (5):1169-1188.

Strine Jr., Leo, Aneil Kovvali, and Oluwatomi Williams. 2021. “Lifting Labor's Voice: A Principled Path Toward Greater Worker Voice And Power Within American Corporate Governance." Faculty Scholarship at Penn Law .

Svejnar, Jan. 1981. "Relative Wage Effects of Unions, Dictatorship and Codetermination: Econometric Evidence from Germany." The Review of Economics and Statistics 63 (2):188-197.

Thelen, Kathleen Ann. 1991. Union of Parts: Labor Politics in Postwar Germany. Cornell University Press. 
Uusitalo, Roope and Juhana Vartiainen. 2009. "Finland: Firm Factors in Wages and Wage Changes." In The Structure of Wages: An International Comparison, edited by Edward Lazear and Kathryn Shaw. NBER, University of Chicago Press, 149-178.

Van Den Berg, Annette, Yolanda Grift, and Arjen Van Witteloostuijn. 2000. “Collective Decision Making: Toward a Relational Perspective." American Behavioral Scientist 43 (8):1301-1315.

Van het Kaar, Robbert. 1997. "Amendment of the Dutch Works Councils Act: a few surprises." URL https://www . eurofound. europa. eu/publications/article/1997/amendment-ofthe-dutch-works-councils-act-a-few-surprises

Visser, Jelle. 2021. “OECD/AIAS ICTWSS Database: Detailed Note on Definitions, Measurement, and Sources." OECD .

Vogel, Steven. 2019. "Elizabeth Warren Wants to Stop Inequality Before It Starts." URL https://www.nytimes.com/2019/01/03/opinion/elizabeth-warreneconomic-policy-democrats.html.

Votinius, Jenny. 2012. "Employee Representation at the Enterprise: Sweden." Bulletin of Comparative Labour Relations .

Walters, Jordan David Thomas. 2021. "On the Efficiency Objection to Workplace Democracy." Ethical Theory and Moral Practice .

Wheeler, Jeff. 2002. "Employee Involvement in Action: Reviewing Swedish Codetermination." Labor Studies Journal 26 (4):71-97.

Williamson, Kevin. 2018. "Elizabeth Warren's Batty Plan to Nationalize... Everything." URL https://www.nationalreview.com/2018/08/elizabeth-warren-plannationalize-everything-woos-hard-left/.

Yglesias, Matthew. 2018. "Elizabeth Warren Has a Plan to Save Capitalism." URL https://www.vox.com/2018/8/15/17683022/elizabeth-warren-accountablecapitalism-corporations. 


\section{Figures}

Figure 1: Shareholder Primacy versus Codetermination

(a) Shareholder Primacy

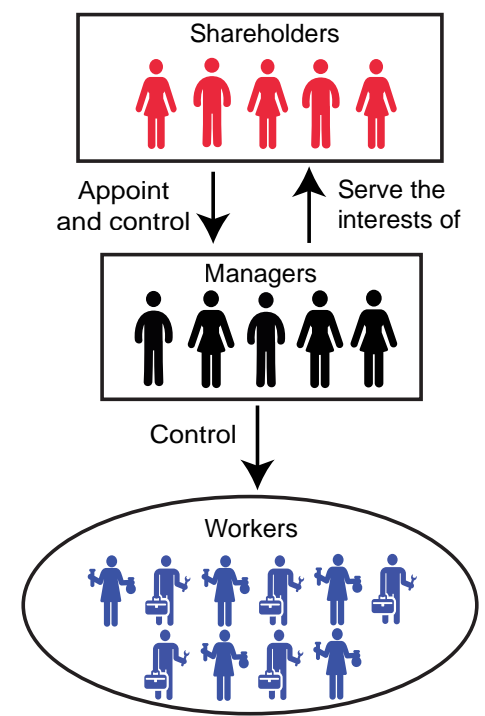

(b) Codetermination

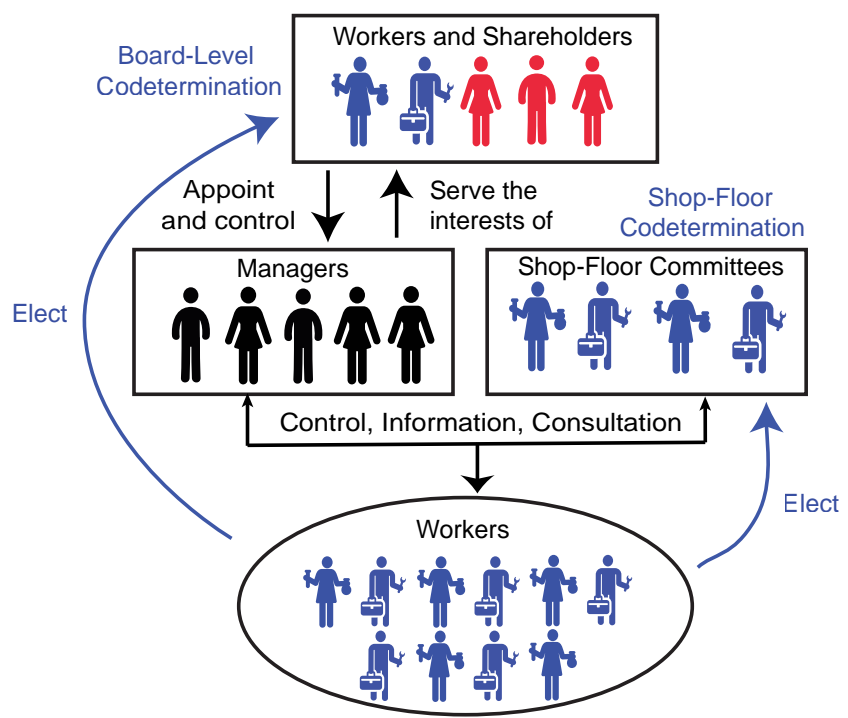

Note: This figure compares the structure of corporate governance under shareholder primacy (Panel (a)) versus codetermination (Panel (b)). 
Figure 2: Institutional Differences Between Codetermined and Non-Codetermined Countries

(a) Primary Level of Collective Bargaining

(b) Union Density
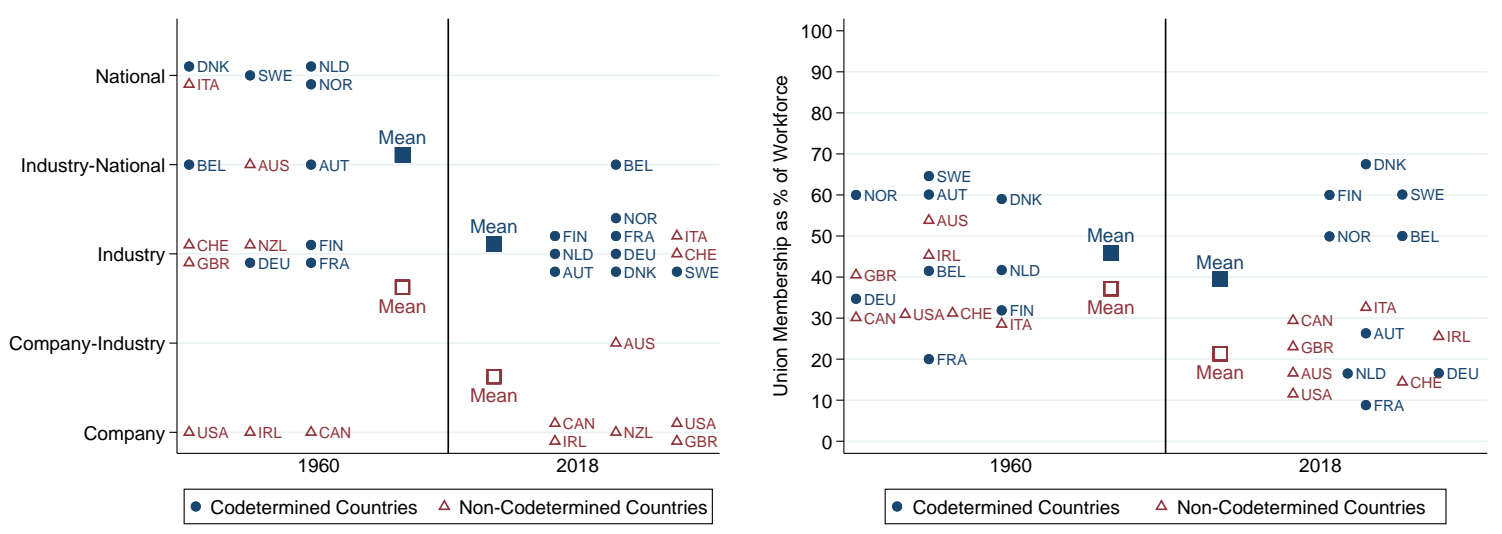

(c) Labor Market Regulation Intensity

(d) Union Density Over Time
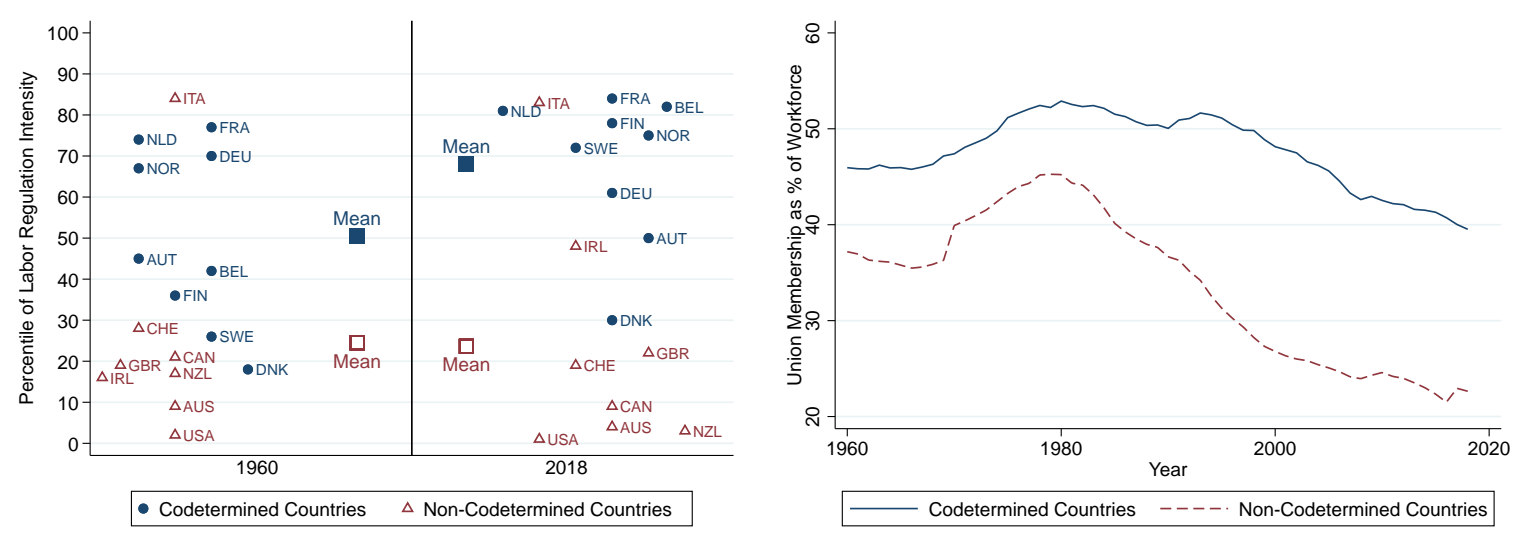

(e) Collective Bargaining Coverage

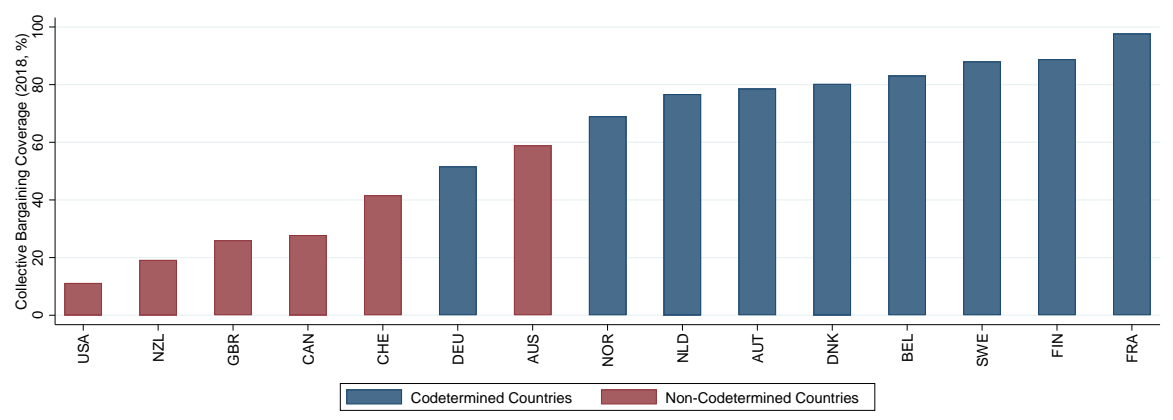

Note: This figure displays institutional differences between countries with and without codetermination laws. The sample of countries consists of the European democracies included in our cross-country event studies, as well as the liberal market economies of the United States, Canada, Australia, and New Zealand. Panel (a) displays the degree of centralization of collective bargaining in each country in 1960 and in 2018, on a 1-5 point scale. Panel (b) displays union density (the percentage of workers who belong to a union) in each country in 1960 and 2018, and Panel (d) presents a time-series plot of the unweighted mean union density in the codetermined versus non-codetermined groups. Panel (d) displays the percentage of employees in each country covered by a collective bargaining agreement in 2018. Data for Panels (a), (b), (d), and (e) are drawn from the OECD/IAIS ICTWSS dataset (Visser. 2021). Panel (c) presents each country's percentile ranking worldwide in terms of the overall intensity of labor regulations, in 1970 and 2013. The overall intensity of labor regulations is measured by the sum of all the labor regulation variables in the CBR Labor Regulation Index (Adams, Bishop, and Deakin. 2016), excluding the variables about codetermination and unionization. The global sample within which our sample of countries are ranked consists of the 84 countries in the CBR dataset with nonmissing data back to 1970. Across all panels, within the "1960" and "Z1518" columns, horizontal dispersion in the dots does not signify anything; it is just to make the dot labels readable. The same holds for, in Panel (a), the slight vertical dispersion around the "Industry" and "National" collective bargaining levels. 


\section{Figure 3: Effects of Codetermination Reforms on Aggregate Outcomes}

(a) Wage Growth (ppt)

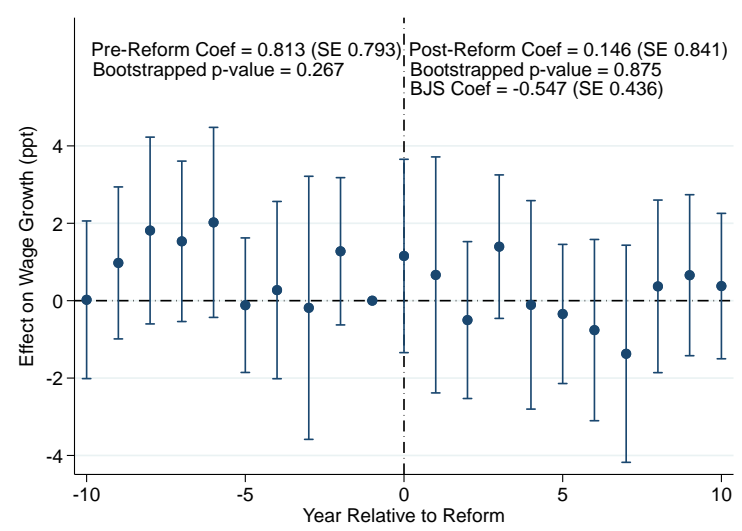

(c) TFP Growth (ppt)

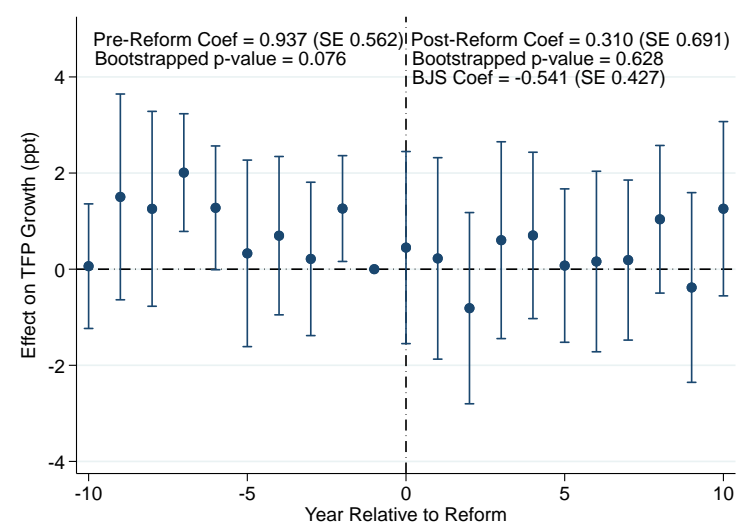

(e) GDP per Capita Growth (ppt)

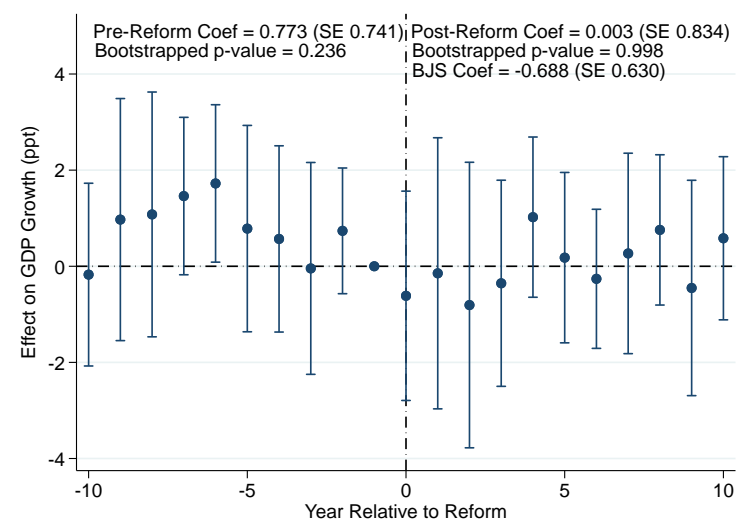

(b) Labor Share (ppt)

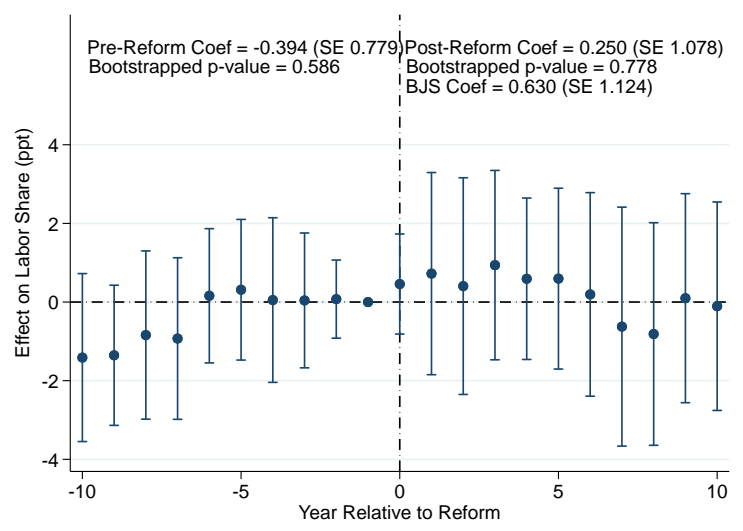

(d) Net Capital Formation (ppt of GDP)

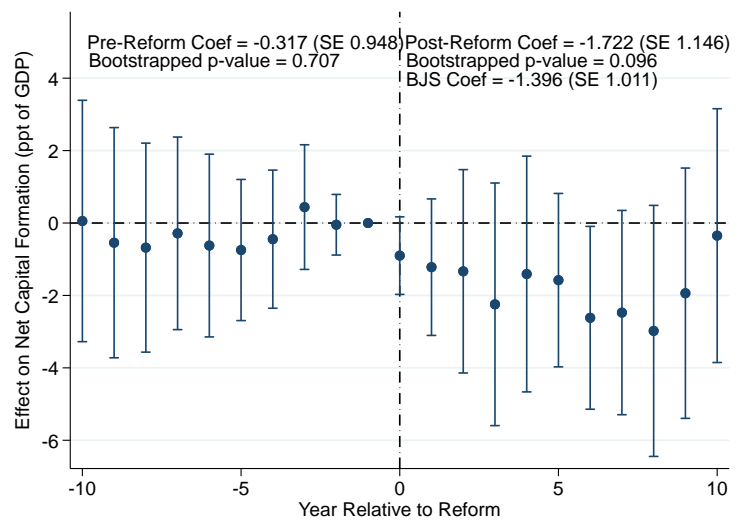

(f) Bottom 90\%'s Share of Income (ppt)

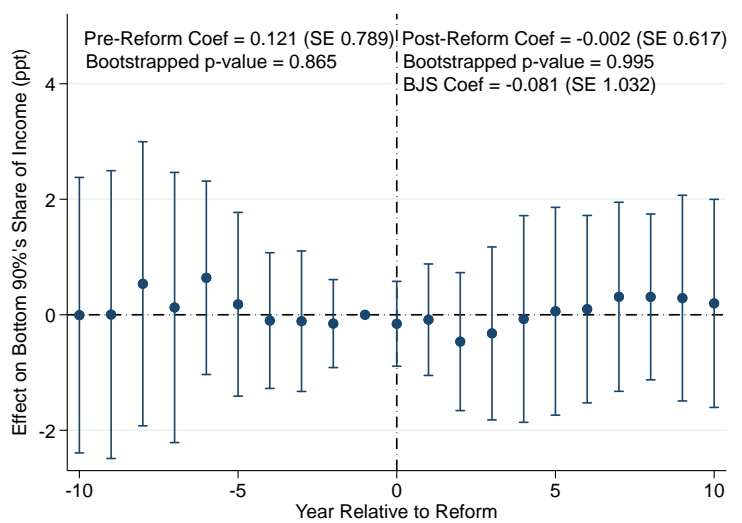

Note: These panels present coefficients from difference-in-differences regressions where the outcome variable is an aggregate economic outcome, the coefficients represent the effects of codetermination reforms, and the sample is our full list of country-reforms and their respective synthetic control units (the sample in Panel (f) differs from the sample in the others, for reasons described in Appendix Section B.6.). In Panel (a), the dependent variable is wage growth in year $t$ (compared to year $t-1$, in \%); in Panel (b), the dependent variable is labor income as a share of GDP in year $t$ (in \%); in Panel (c), it is total factor productivity growth in year $t$ (in \%); in Panel (d), it is net capital formation in year $t$ as a \% of year $t$ GDP; in Panel (e), it is growth in GDP per capita in year $t(\%)$; and in Panel (f), it is the share of national income held by the bottom $90 \%$. Standard errors are clustered at the country-reform level. We report average pre-reform and average post-reform coefficients, and report bootstrapped $p$-values for those coefficients due to the small number of clusters. In addition, we report post-reform coefficients estimated using the imputatioßnmethodology developed by Borusyak, Jaravel, and Spiess (2021). See Appendix Sections B.1 B.7 for a full description of the sample, data, and methodology. 
Figure 4: Codetermination and Industrial Relations

(a) Event Study: Strike Intensity

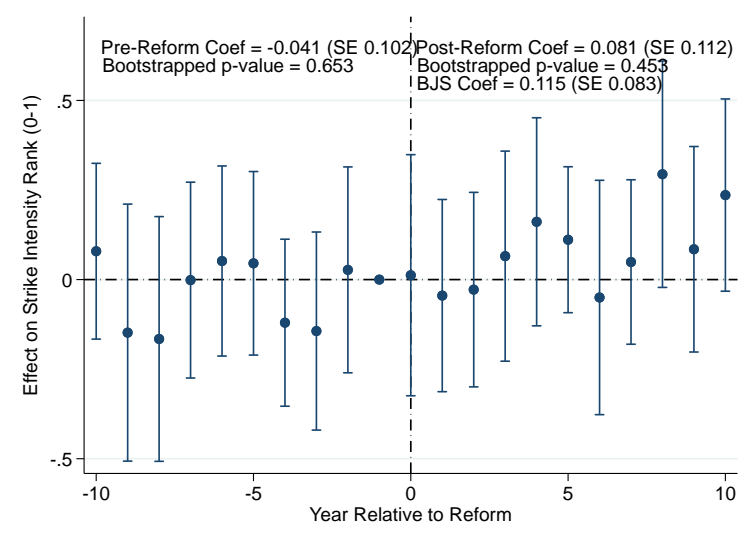

(b) Event Study: Union Density Growth

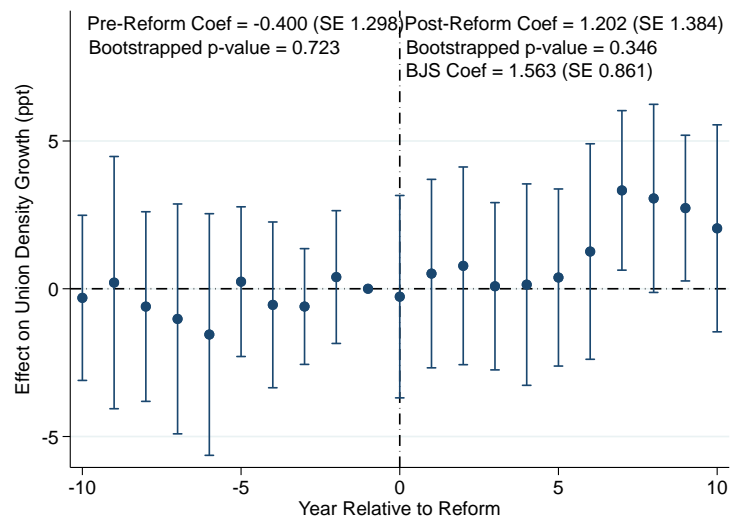

(c) Cross-Sectional: Codetermination Laws and Cooperativeness in Industrial Relations

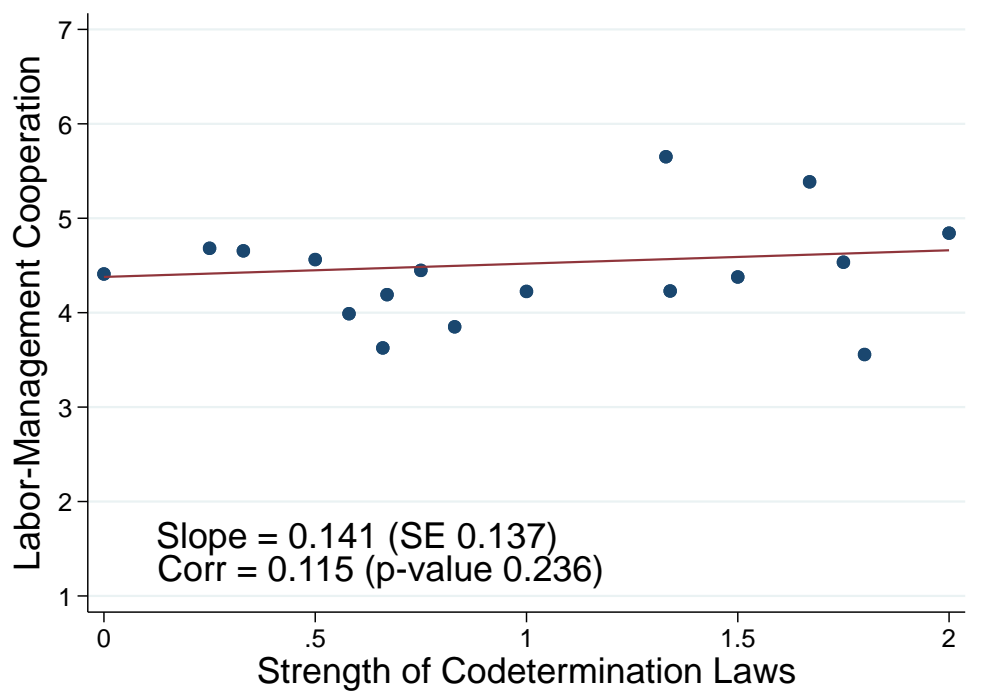

Note: Panels (a) and (b) plot coefficients from our standard cross-country event study specifications (see Note to Figure 3, for industrial relations outcome variables. The dependent variable in Panel (a), strike intensity, is a continuous variable between 0 and 1 , with a value of 1 representing the highest-ranked year in that country (the year with the most intense strike activity). A positive coefficient means an increase in strike intensity, and a negative coefficient represents a decrease in strike intensity. The dependent variable in Panel (b) is union density growth in year $t$ relative to year $t-1$, in \%. Panel (c) is a binned scatter plot displaying the cross-sectional correlation between the strength of a country's codetermination laws (as measured by the CBR Labor Regulation Index) and the degree of cooperativeness in the country's industrial relations (as measured by a 1-7 point survey item from the World Economic Forum's Executive Opinion survey, described in Appendix Section B.3). We report the slope of the relationship, a robust standard error, and a correlation coefficient and p-value. 
Figure 5: Informal Worker Involvement in the 2013 and 2019 European Company Survey

(a) Worker Involvement (2013 ECS)

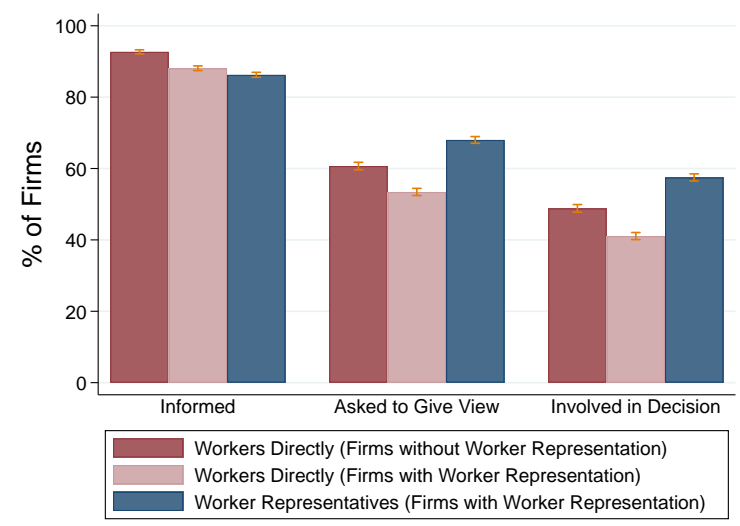

(c) Involvement by Firm Size (2013 ECS)

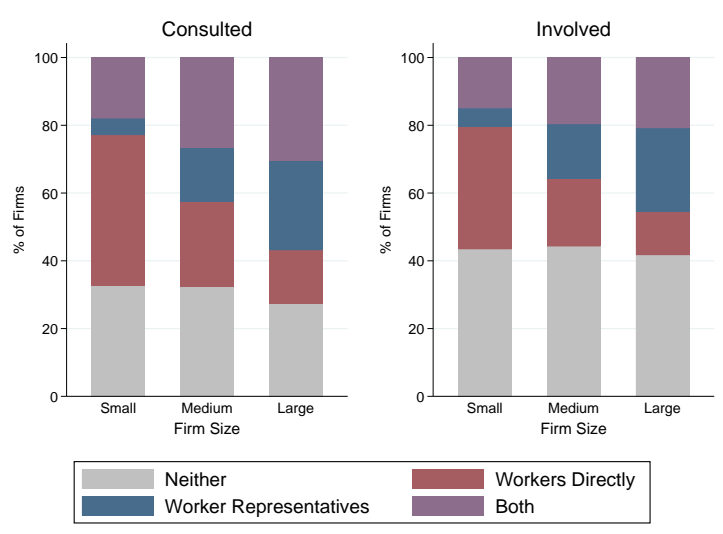

(b) Worker Influence (2019 ECS)

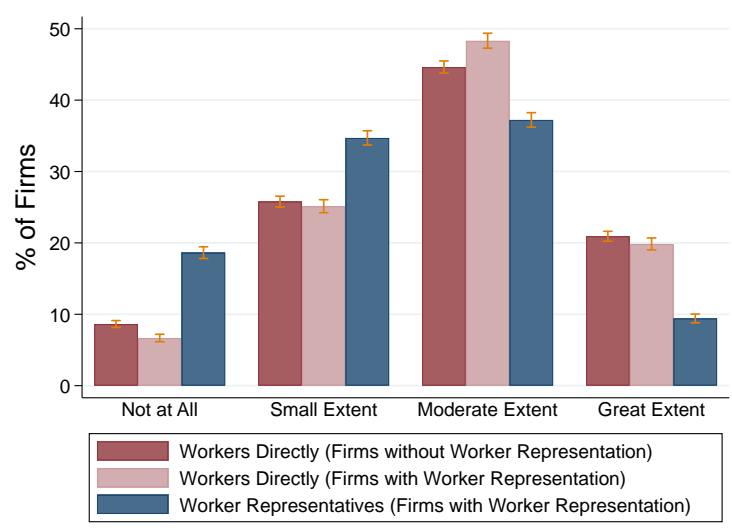

(d) Codetermination Laws vs Involvement

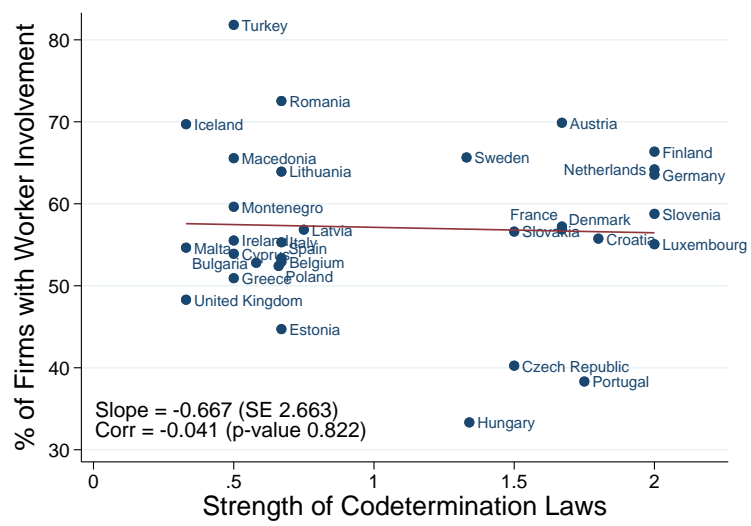

Note: Panel (a): the 2013 ECS asks managers if, in the past 3 years, their firm underwent a major change in any of a list of areas (remuneration, use of technology, work organization/allocation, recruitment policies, and working time arrangements). The $68 \%$ of managers who say "yes" are asked which one was the most important change, and then asked whether workers were directly (1) informed in advance about that change, (2) consulted about that change, or (3) involved in decision-making about that change. Managers in establishments with worker representation are additionally asked whether worker representatives were informed, consulted, or involved in the decision. The dark red bars plot responses about direct involvement from managers in firms without formal worker representatives. Light red bars plot responses about direct involvement from firms with worker representatives, and blue bars plot responses about worker representative involvement in firms with worker representation. Panel (b): in the 2019 ECS, managers are asked how much influence workers directly exercise over decisions about the organization of work. Managers in firms with worker representation are also asked about the influence of worker representatives. Responses are plotted in dark red, light red, and blue bars analogous to those in Panel (a). The same questions are also asked about decision-making in four other areas; responses in those four areas are plotted in Appendix Figure A.15 Panel (c) plots responses to the same questions as Panel (a), split up by firm size (small firms are those with fewer than 50 workers; medium firms are between 50 and 250; large firms are 250+). Grey bars represent firms where workers were not involved at all in the last major decision, red bars represent firms where workers were directly involved (and worker representatives were not involved), blue bars represent firms where worker representatives were involved (and workers were not directly involved), and purple bars represent firms where both workers directly and worker representatives were involved. All firms, including those without formal worker representation, are included. Panel (d): presents a scatterplot from a regression of the percentage of firms in a country who involved workers or worker representatives in their last major decision (from the same questions as Panels (a) and (c)) on a measure of the strength of board-level and shop-floor representation laws (calculated from the CBR Labor Regulation Index, Adams, Bishop, and Deakin. 2016. 


\section{Online Appendix of: \\ What Does Codetermination Do? \\ Simon Jäger, Shakked Noy, Benjamin Schoefer}

\section{Contents}

\begin{tabular}{|r|r|}
\hline A Appendix Figures & 39 \\
\hline
\end{tabular}

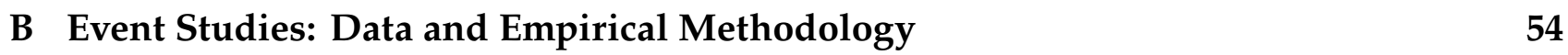

B.1 Sample Construction and Identifying Codetermination Reforms . . . . . . . . 54

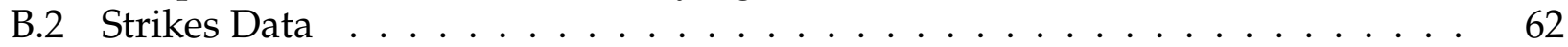

B.3 Cooperative Industrial Relations Data . . . . . . . . . . . . . . . . . . . . . . 64

B.4 Union Density Data $\ldots \ldots \ldots \ldots \ldots$

B.5 Macroeconomic Data . . . . . . . . . . . . . . . . . . . . 65

B.6 Income Inequality Data $\ldots \ldots \ldots \ldots 6$

B.7 Empirical Methodology $\ldots \ldots \ldots \ldots$. . . . . . . . . . . . . . . 66

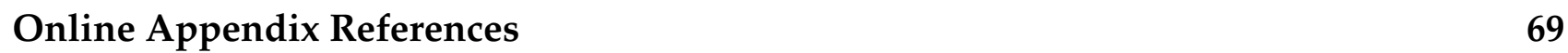

\section{A Appendix Figures}

Figure A.1: Board-Level Representation Worldwide (2015)

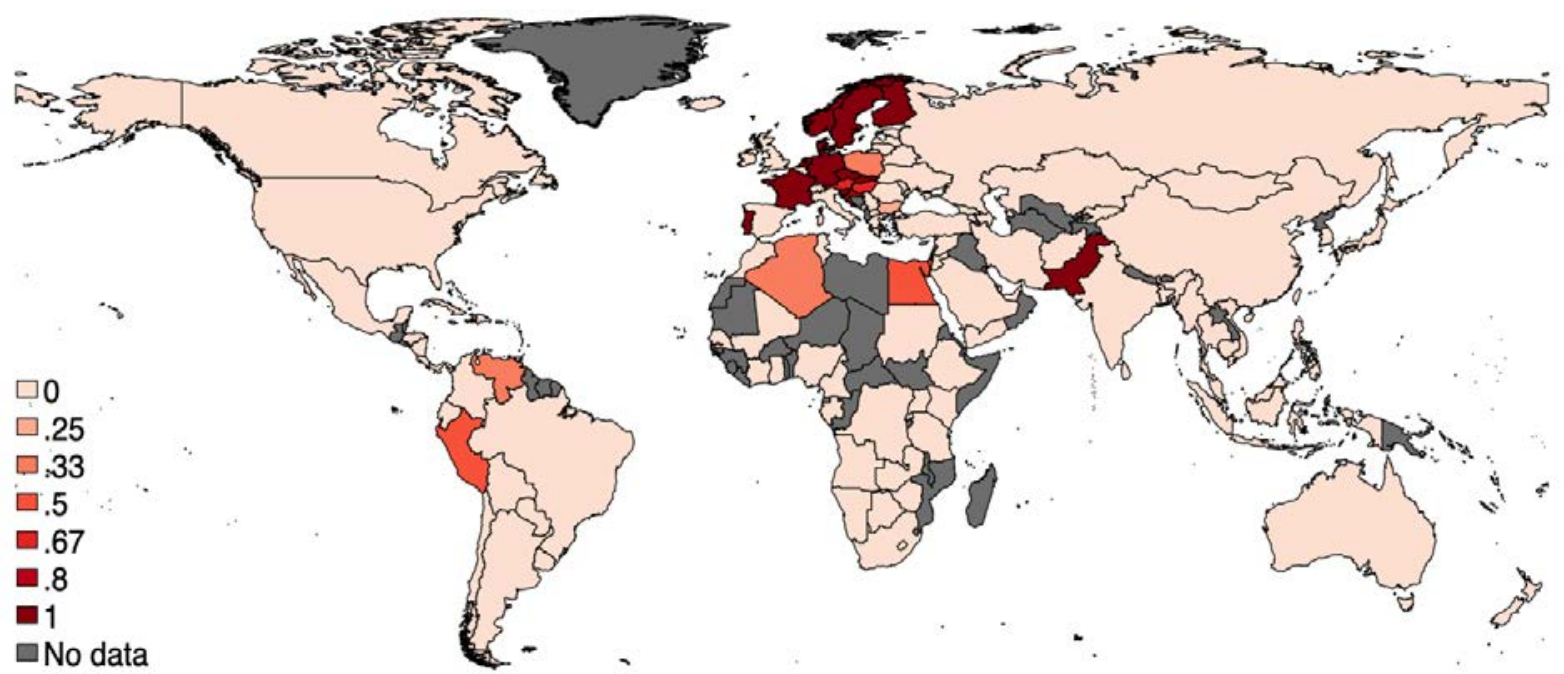

Note: This map displays the existence and strength of laws mandating board-level worker representation, as of 2015. A country is assigned a value of 1 if workers in all companies above some size threshold have a right to board-level representation, and 0 if there is no set of companies where workers have this right. Scores between 0 and 1 reflect weaker laws, for example laws requiring only that formerly state-owned companies have board-level worker representatives. Data are from the "Codetermination: board membership" variable in the CBR Labor Regulation Index dataset; see Adams, Bishop, and Deakin (2016) for a complete description of the dataset. 
Figure A.2: Shop-Floor Representation Worldwide (2015)

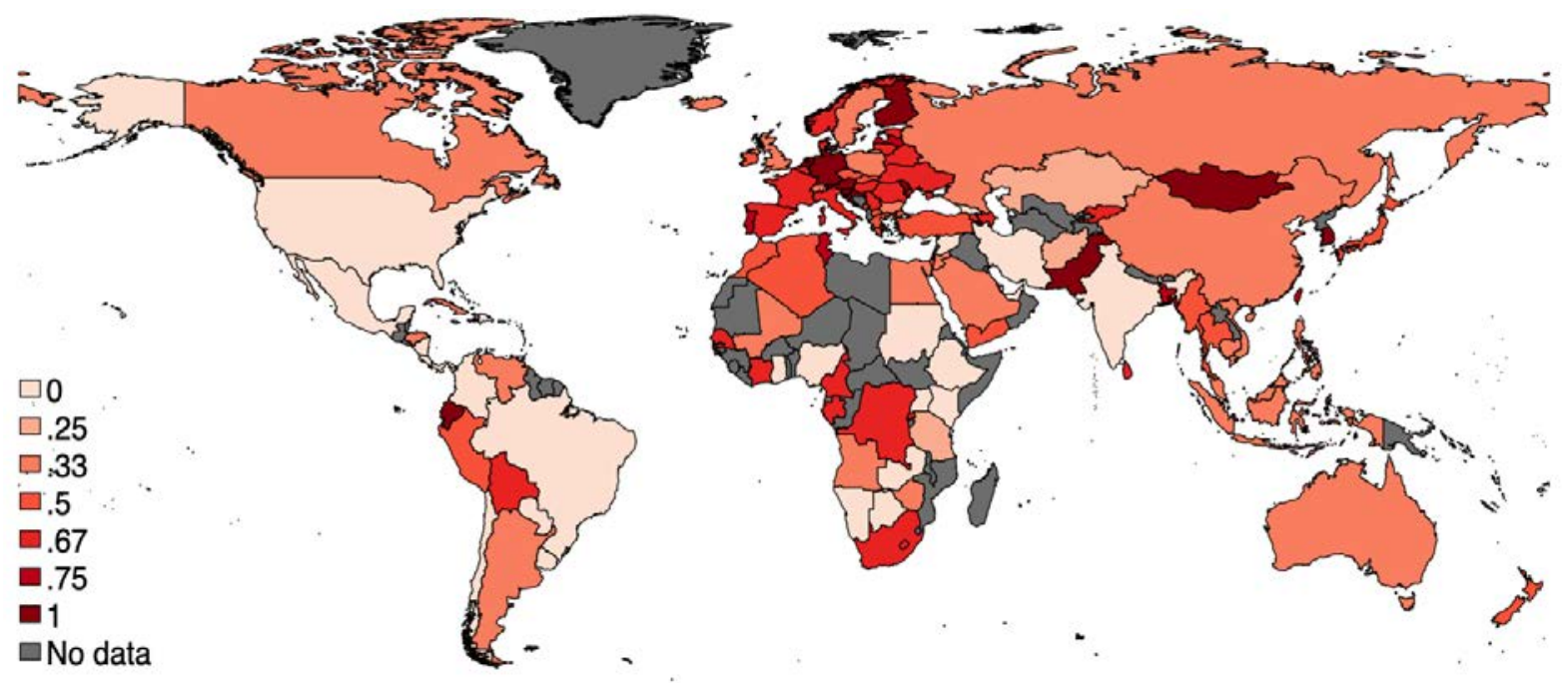

Note: This map displays the existence and strength of laws giving workers rights to shop-floor representation, as of 2015. A country is assigned a value of 1 if a right to shop-floor representation exists and the shop-floor representatives are given co-decision-making powers; a value of 0.67 if a right to shop-floor representation exists but councils do not have co-decision-making powers; a value of 0.5 if a right to shop-floor representation exists except in cases where employers can point to pre-existing alternative arrangements; and a value of 0.33 if workers have rights to information and consultation but not rights to shop-floor representation. There is scope for further idiosyncratic variation between 0 and 1 based on the strength of the laws. Data are from the "Codetermination and information and consultation of workers" variable in the CBR Labor Regulation Index dataset; see Adams, Bishop, and Deakin (2016) for a complete description of the dataset. 
Figure A.3: Aggregate Synthetic Control Plots

(a) Wage Growth (\%)

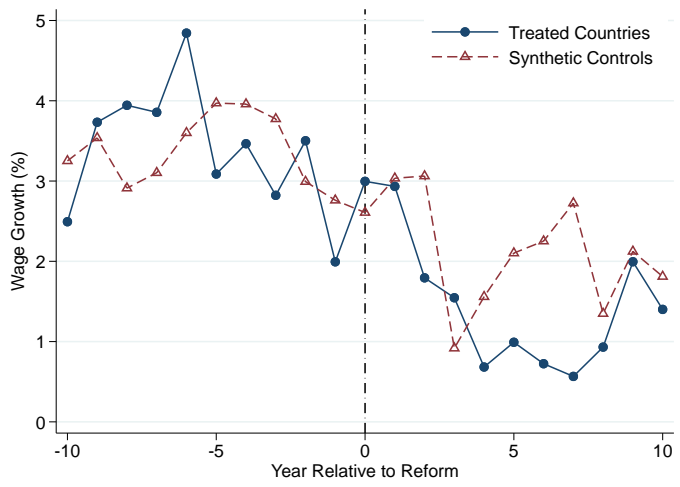

(c) Net Capital Formation (pct of GDP)

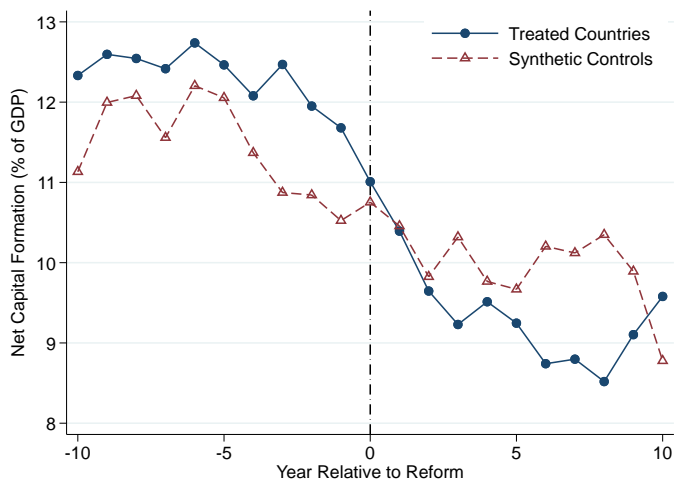

(e) GDP per Capita Growth (\%)

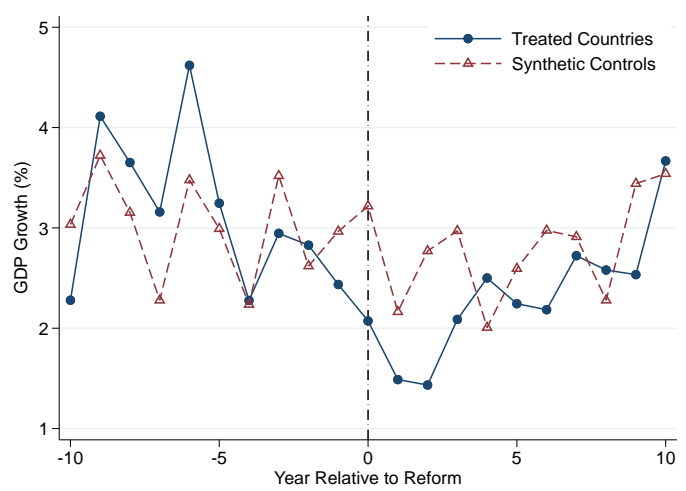

(b) Labor Share (pct)

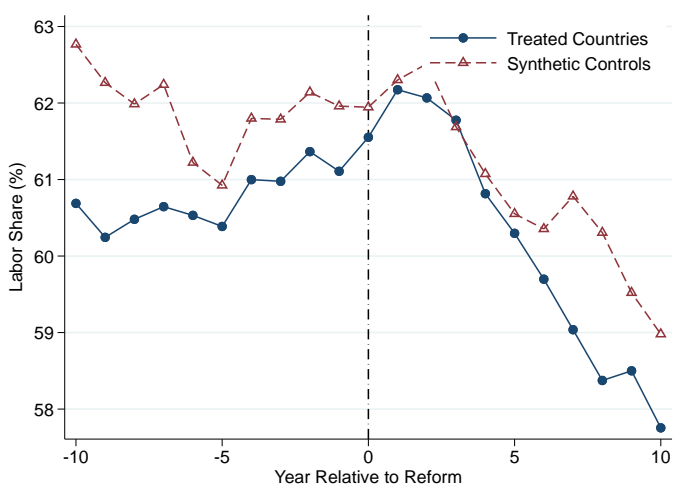

(d) TFP Growth (\%)

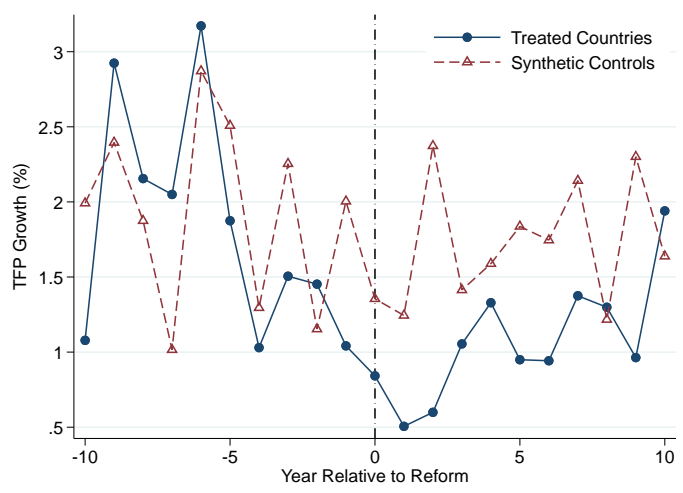

(f) Bottom 90\%'s Share of Income (\%)

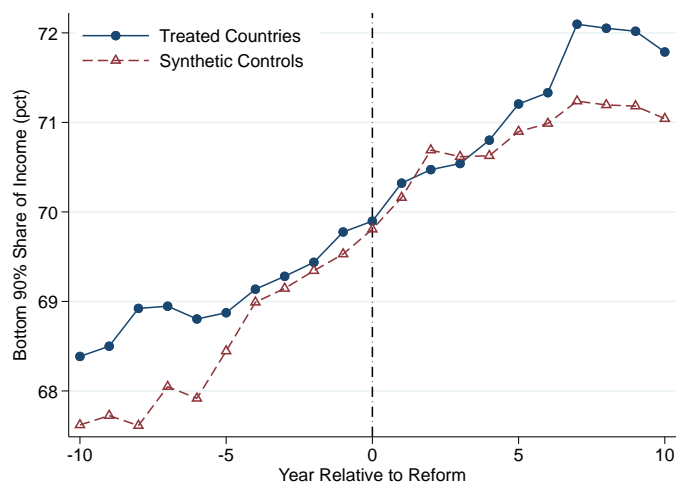

Note: For each of our dependent variables, this figure plots the raw time series in our group of treated country-reforms and our group of synthetic control units. The blue (solid circle) line represents the outcome variable averaged across our treated country-reforms, and the red (hollow triangle) line is averaged across our synthetic control units. 
Figure A.4: Validation Check for Aggregate Synthetic Control Plots

(a) Wage Growth (\%)

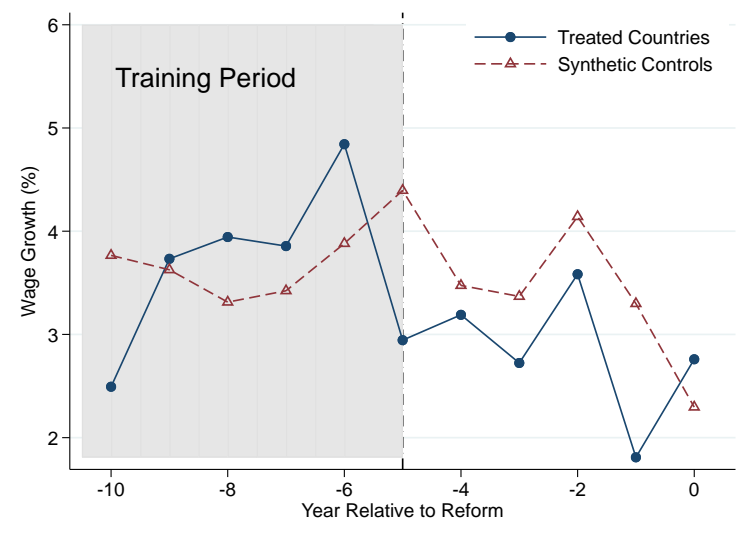

(c) Net Capital Formation (pct of GDP)

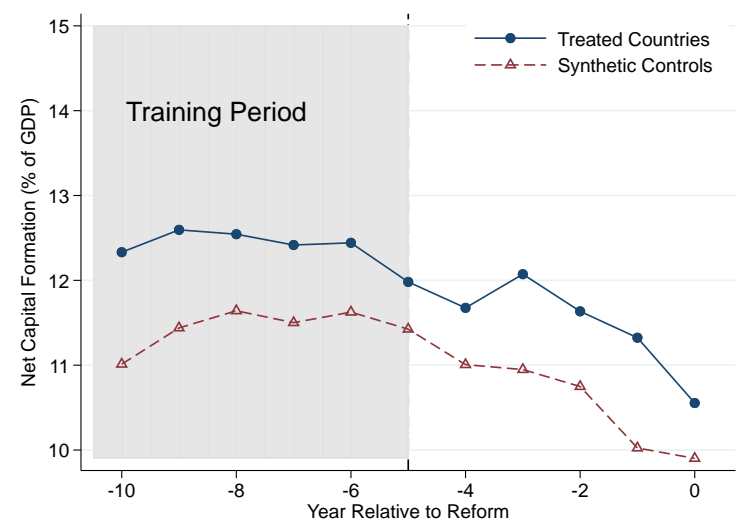

(e) GDP per Capita Growth (\%)

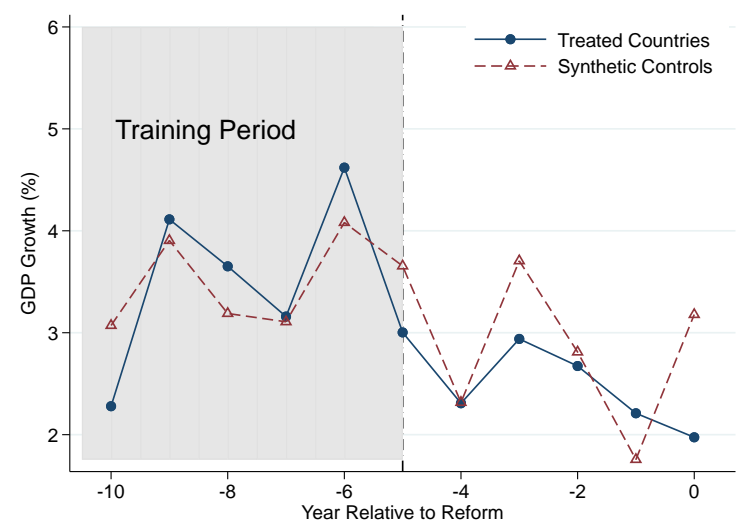

(b) Labor Share (pct)

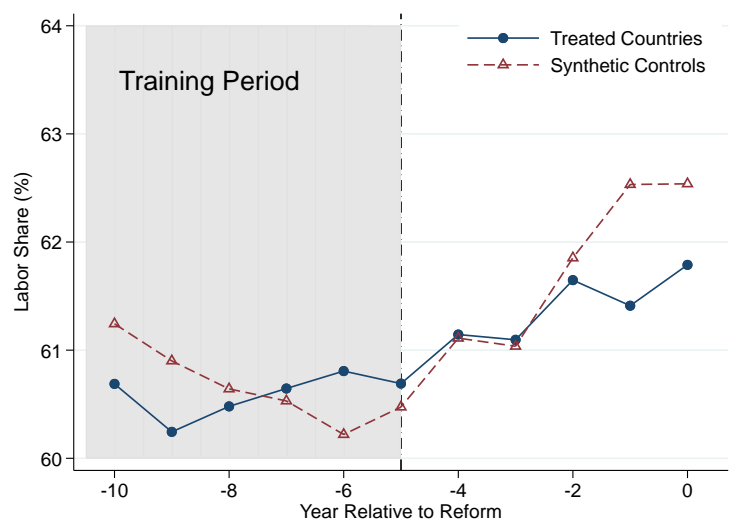

(d) TFP Growth (\%)

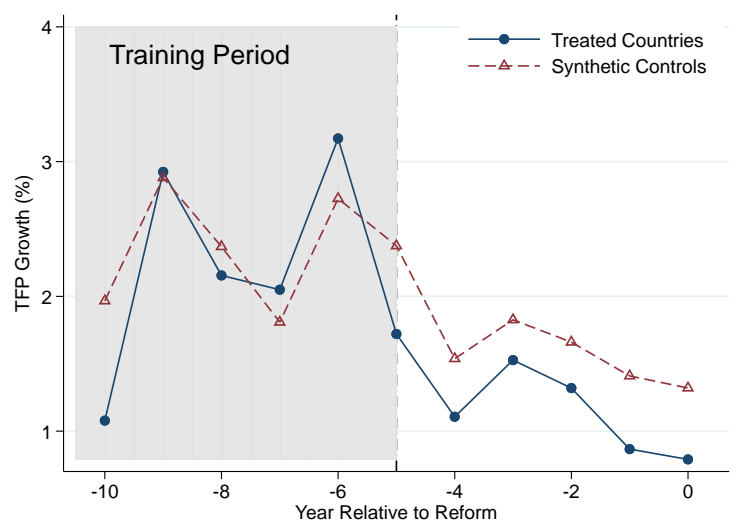

(f) Bottom 90\%'s Share of Income (\%)

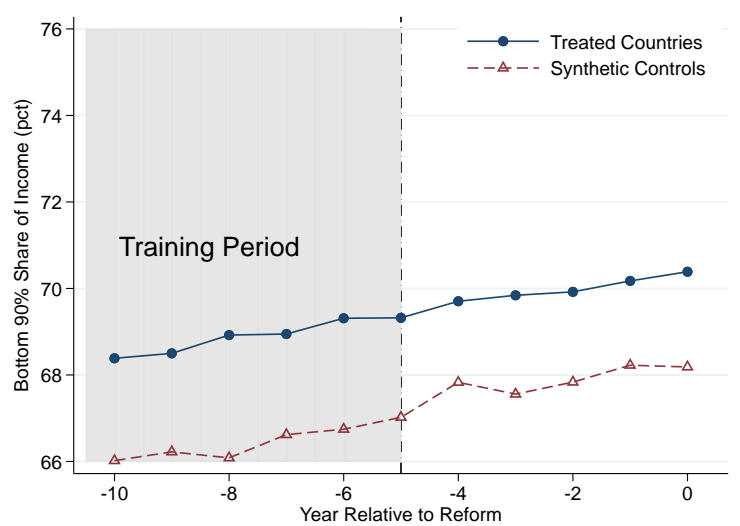

Note: This figure replicates Figure A.3. but matches the synthetic control units only on the first half of the pre-reform period, and plots the results in the second half of the pre-reform period, to check the quality of the synthetic control fits. The 1966 Norwegian reform is excluded from this plot because we only have 6 years of pre-period data for that reform. 
Figure A.5: Synthetic Control Plots (Austria 1975)

(a) Wage Growth (\%)

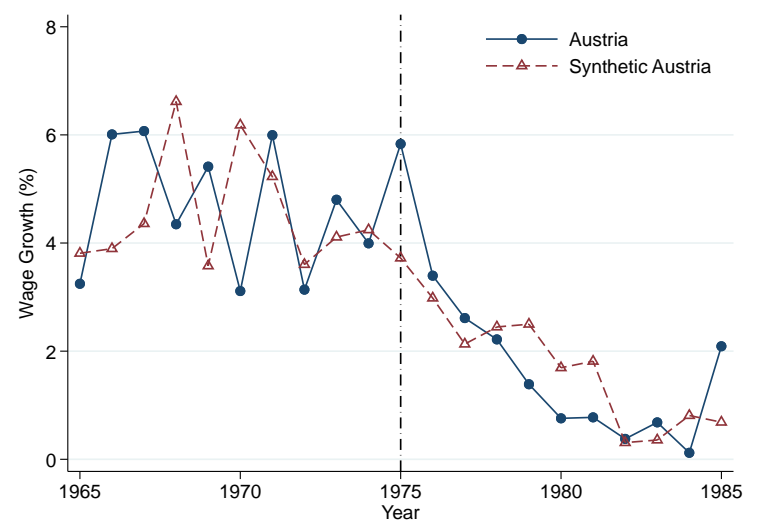

(c) Net Capital Formation (pct of GDP)

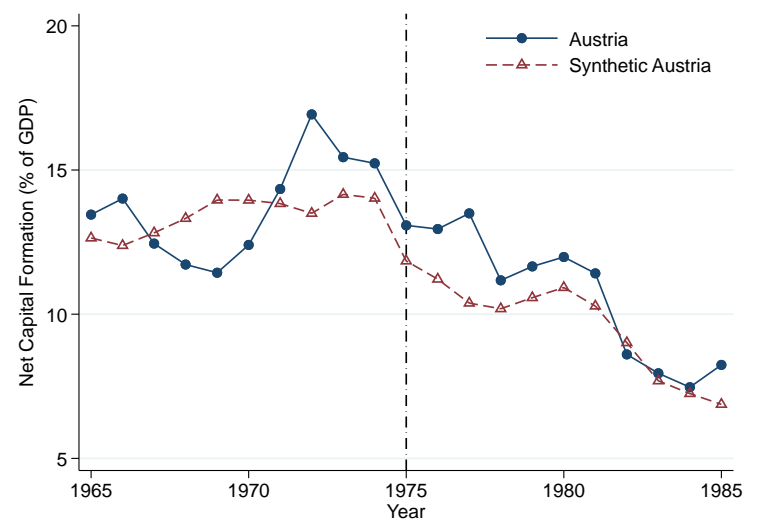

(b) Labor Share (pct)

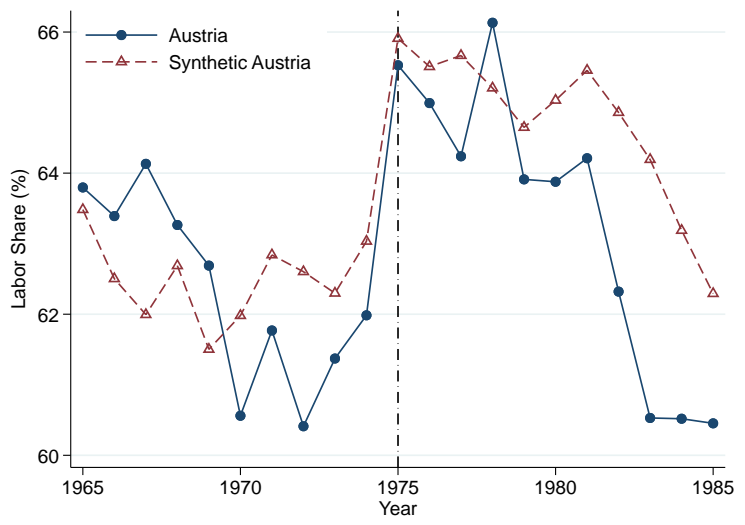

(d) TFP Growth (\%)

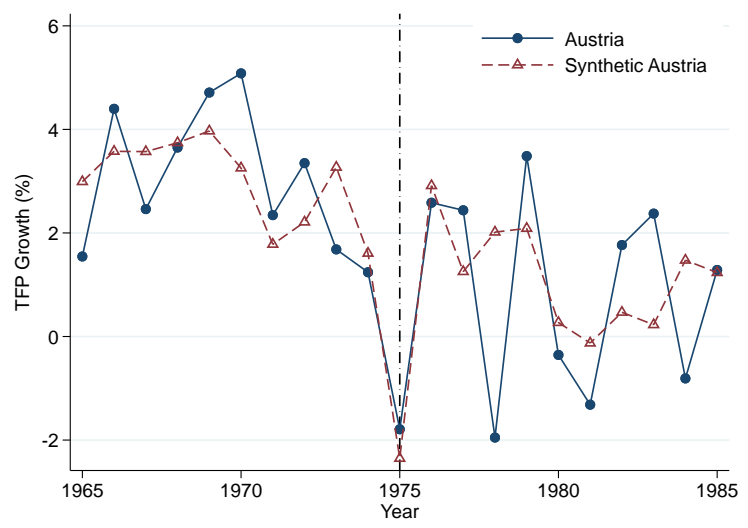

(e) GDP Per Capita Growth (\%)

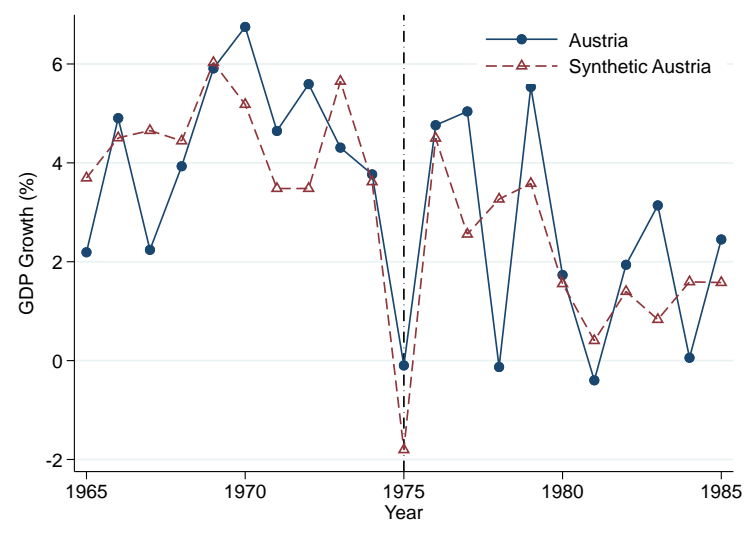

Note: For each of our dependent variables, this figure plots the raw time series in Austria (blue, solid circles) compared to its synthetic control unit (red, hollow triangles), in the 21-year period surrounding Austria's 1975 codetermination reform. There is no Panel (f) because Austria is missing data back to 1960 for our "income inequality" outcome variable and is therefore excluded from the income inequality analyses. 
Figure A.6: Synthetic Control Plots (Denmark 1973)

(a) Wage Growth (\%)

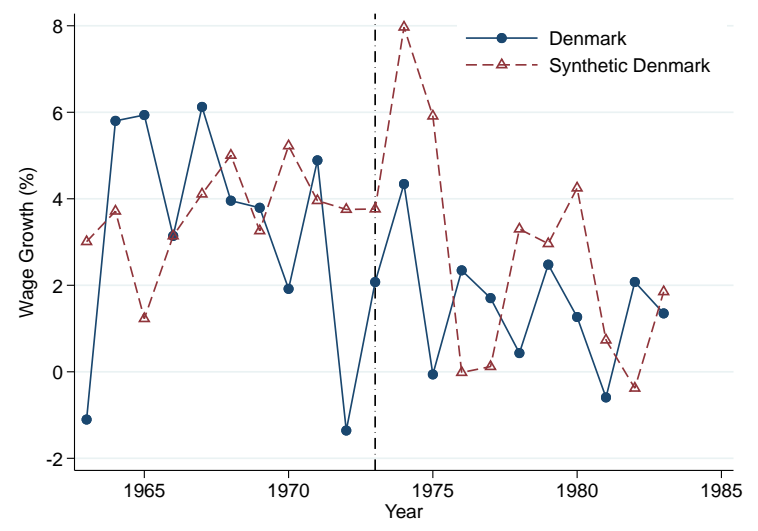

(c) Net Capital Formation (pct of GDP)

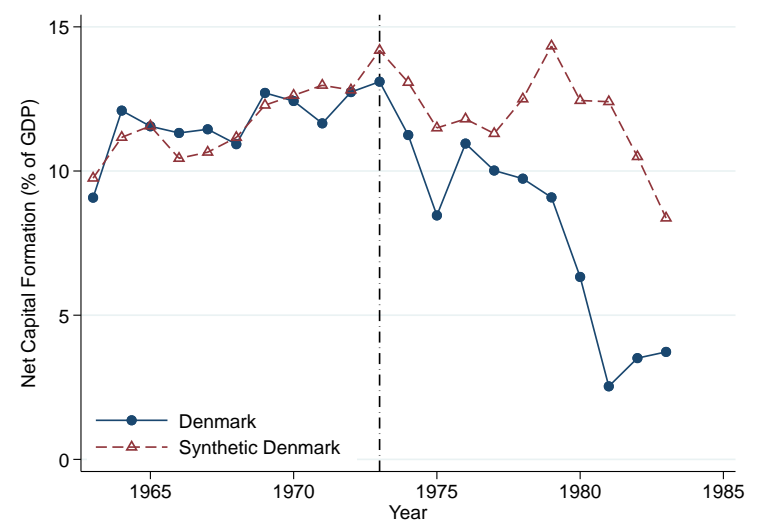

(e) GDP per Capita Growth (\%)

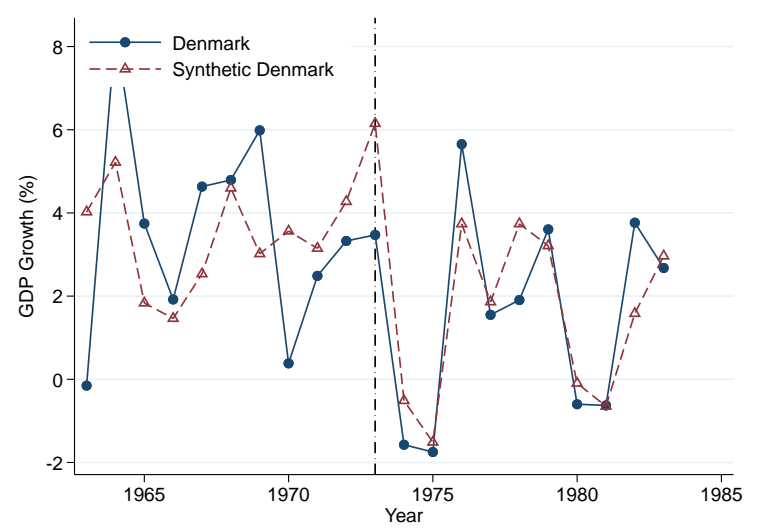

(b) Labor Share (pct)

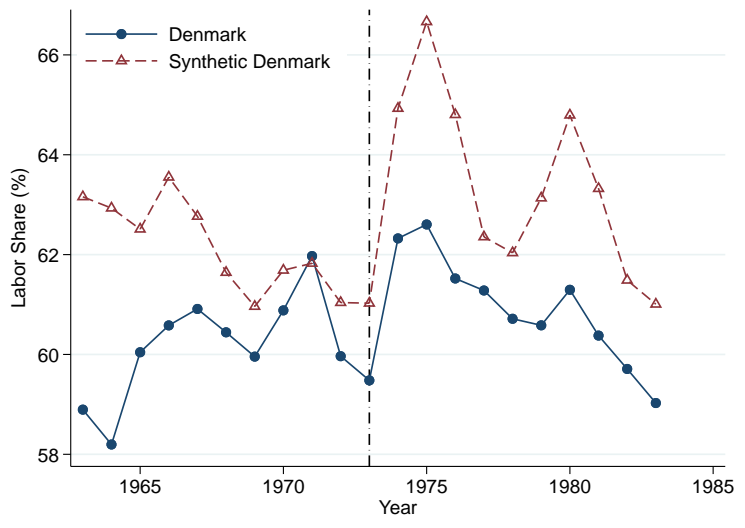

(d) TFP Growth (\%)

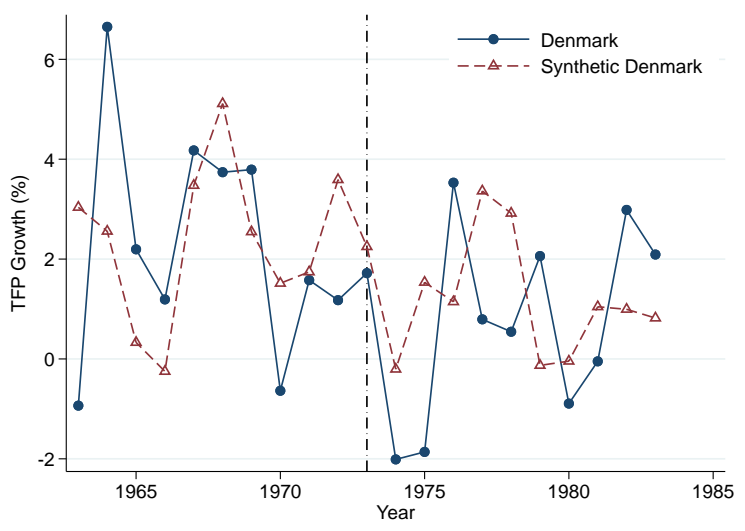

(f) Bottom 90\%'s Share of Income (\%)

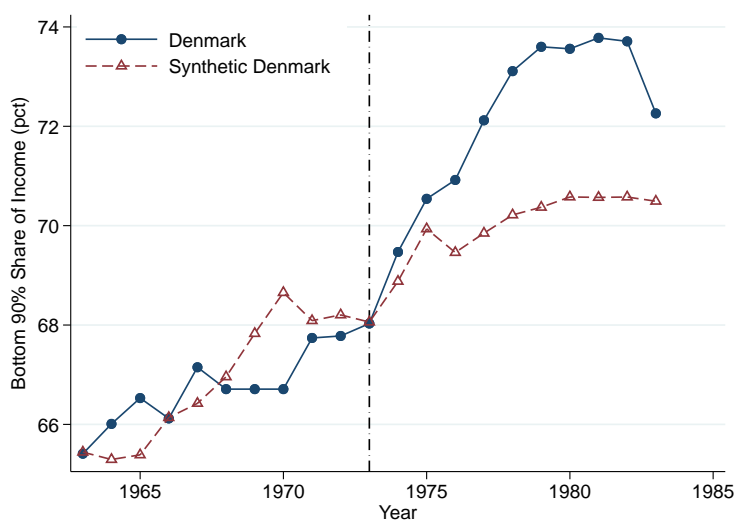

Note: For each of our dependent variables, this figure plots the raw time series in Denmark (blue, solid circles) compared to its synthetic control unit (red, hollow triangles), in the 21-year period surrounding Denmark's 1973 codetermination reform. 
Figure A.7: Synthetic Control Plots (Finland 1978)

(a) Wage Growth (\%)

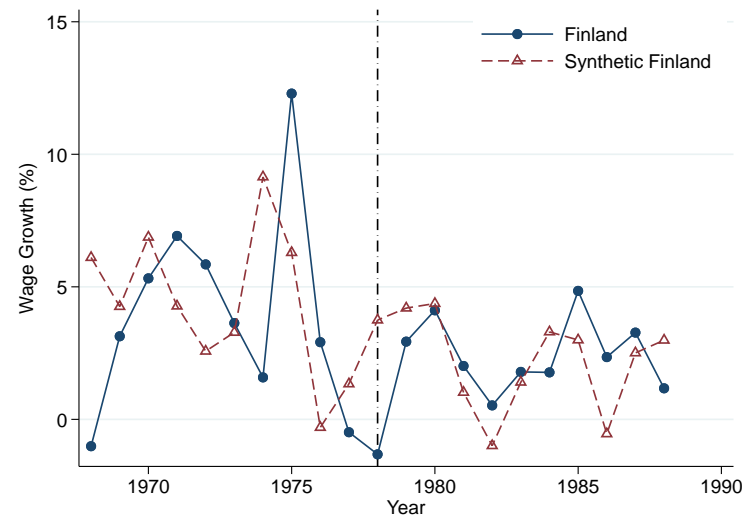

(c) Net Capital Formation (pct of GDP)

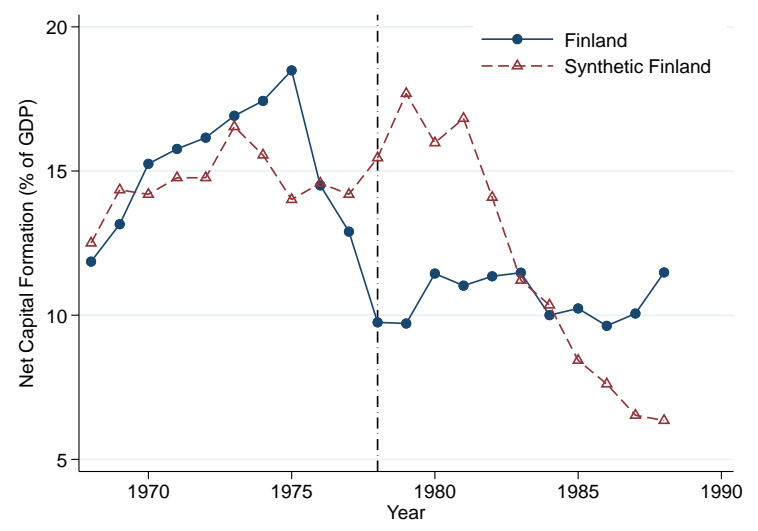

(b) Labor Share (pct)

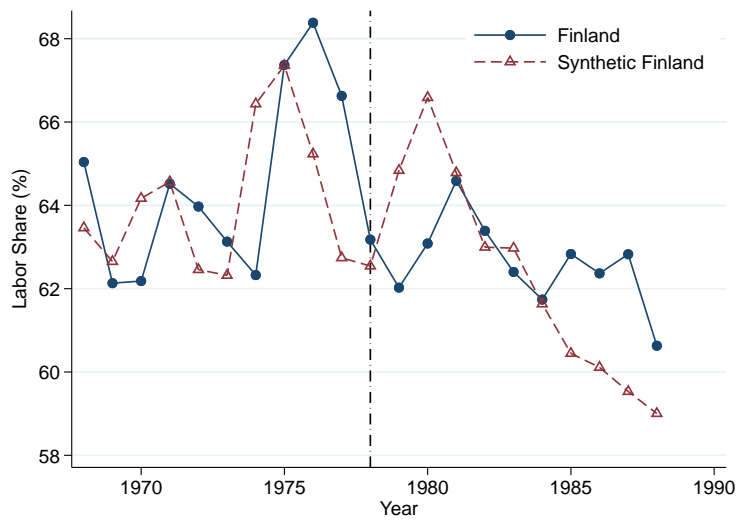

(d) TFP Growth (\%)

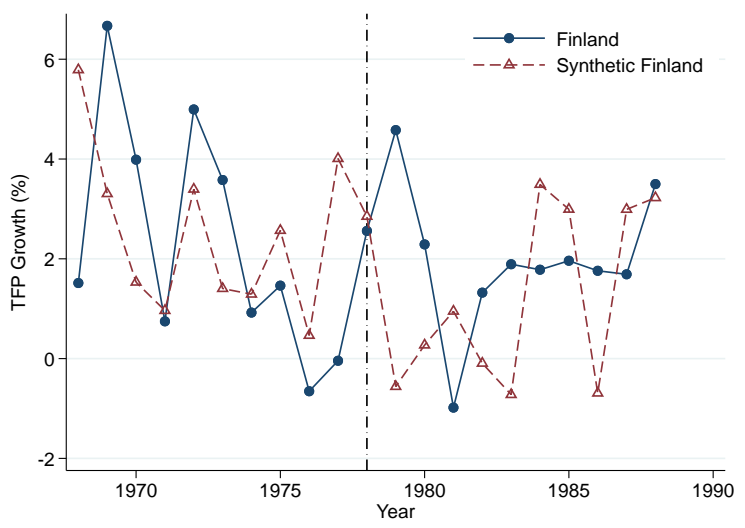

(e) GDP per Capita Growth (\%)

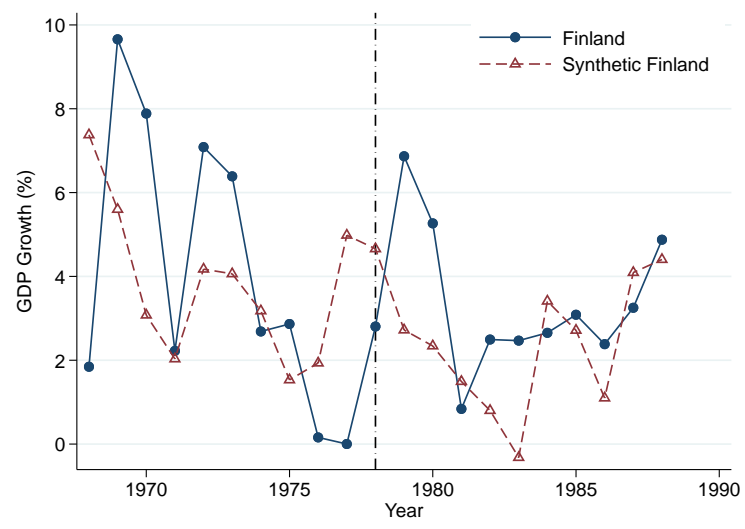

Note: For each of our dependent variables, this figure plots the raw time series in Finland (blue, solid circles) compared to its synthetic control unit (red, hollow triangles), in the 21-year period surrounding Finland's 1978 codetermination reform. There is no Panel (f) because Finland is missing data back to 1960 for our "income inequality" outcome variable and is therefore excluded from the income inequality analyses. 
Figure A.8: Synthetic Control Plots (Finland 1990)

(a) Wage Growth (\%)

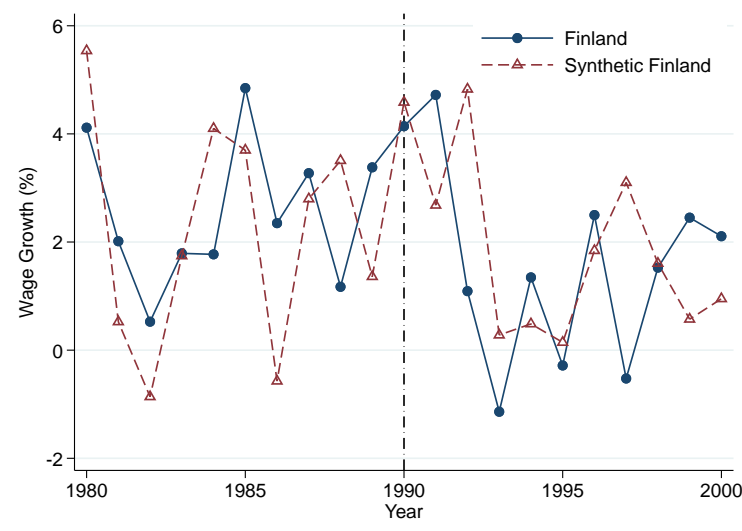

(c) Net Capital Formation (pct of GDP)

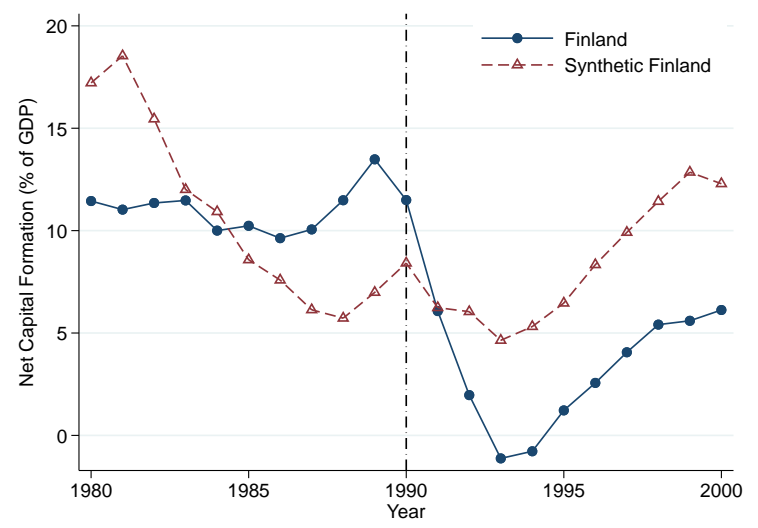

(b) Labor Share (pct)

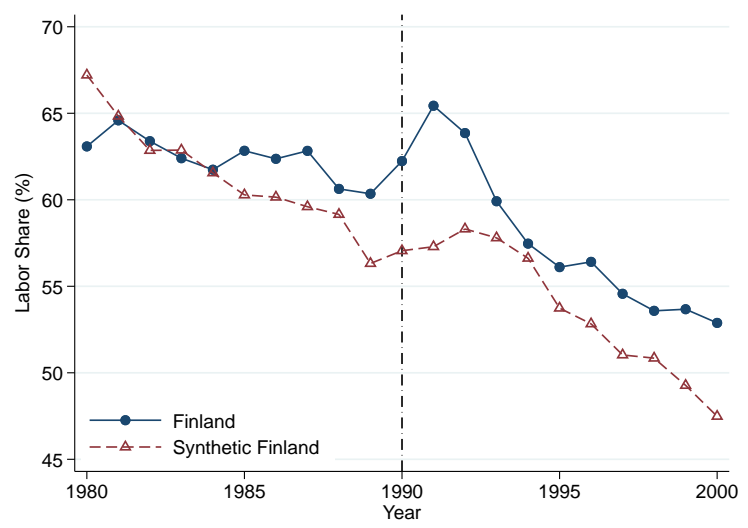

(d) TFP Growth (\%)

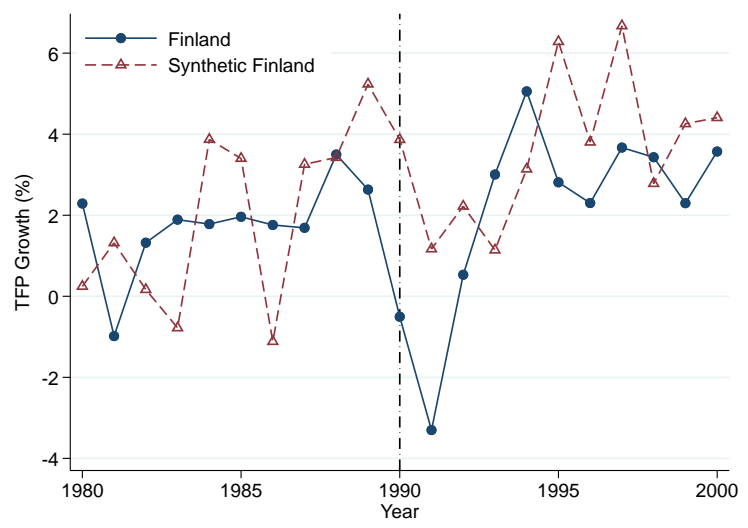

(e) GDP per Capita Growth (\%)

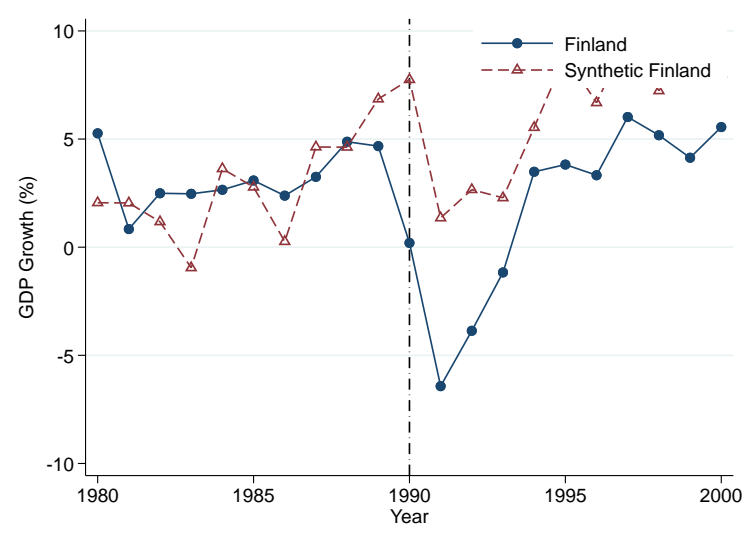

Note: For each of our dependent variables, this figure plots the raw time series in Finland (blue, solid circles) compared to its synthetic control unit (red, hollow triangles), in the 21-year period surrounding Finland's 1990 codetermination reform. There is no Panel (f) because Finland is missing data back to 1960 for our "income inequality" outcome variable and is therefore excluded from the income inequality analyses. 
Figure A.9: Synthetic Control Plots (France 2013)

(a) Wage Growth (\%)

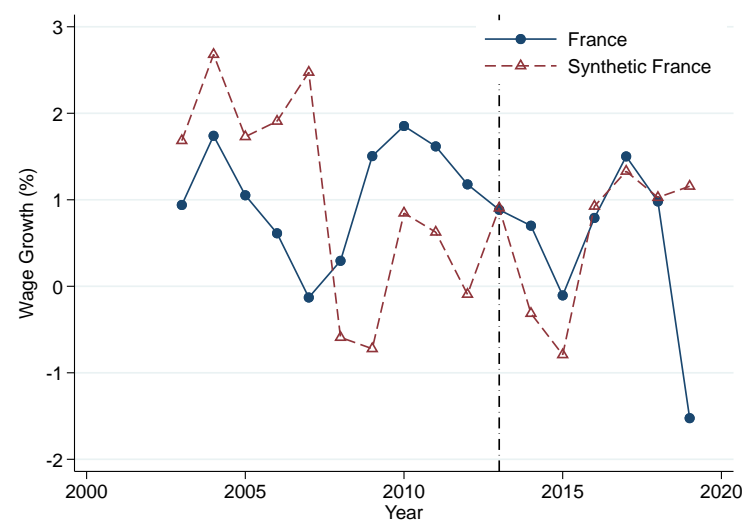

(c) Net Capital Formation (pct of GDP)

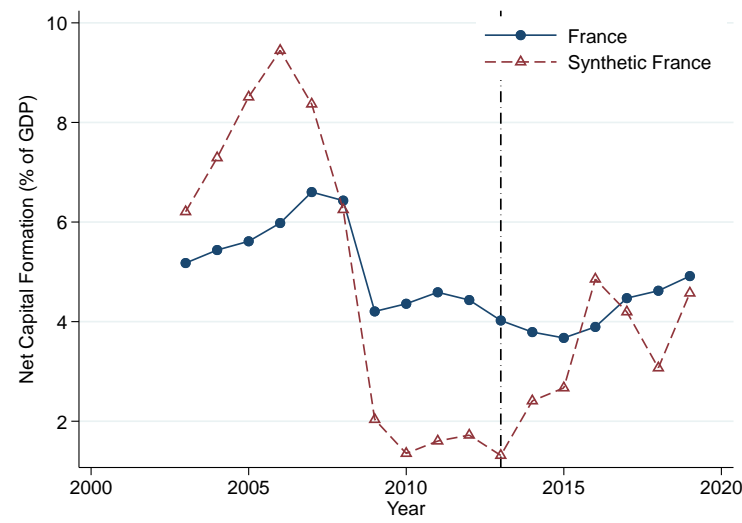

(e) GDP per Capita Growth (\%)

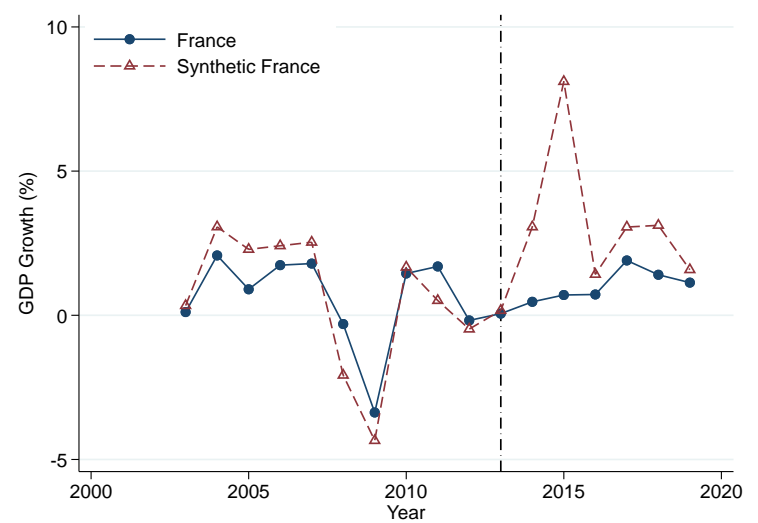

(b) Labor Share (pct)

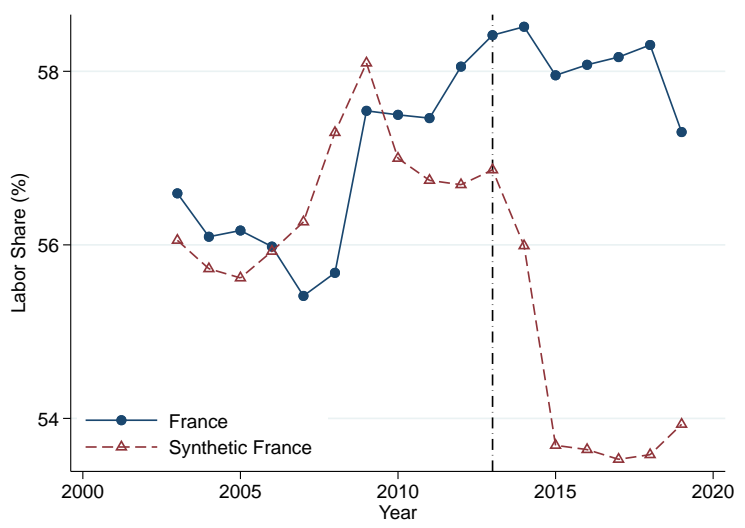

(d) TFP Growth (\%)

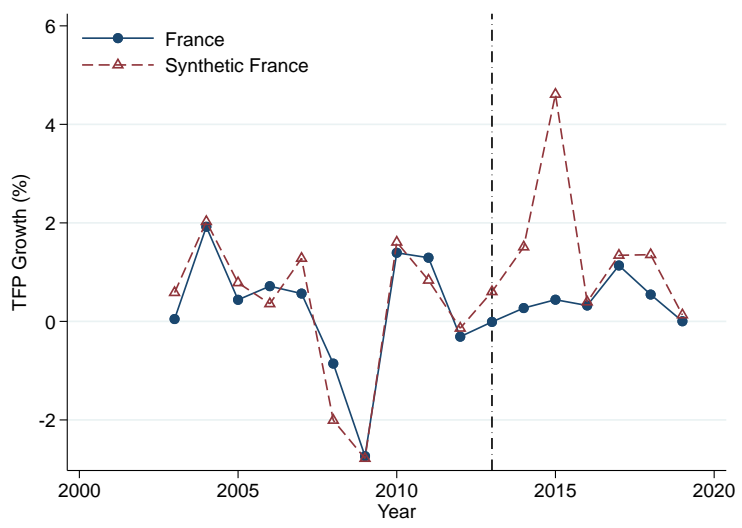

(f) Bottom 90\%'s Share of Income (\%)

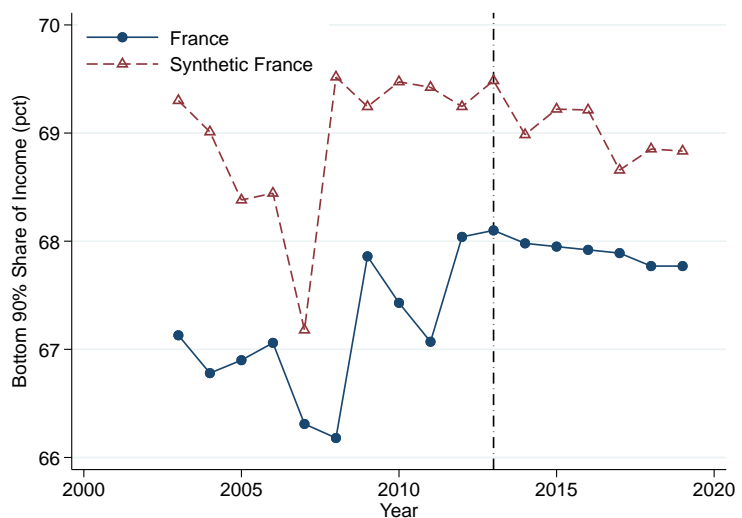

Note: For each of our dependent variables, this figure plots the raw time series in France (blue, solid circles) compared to its synthetic control unit (red, hollow triangles), in the period surrounding France's 2013 codetermination reform. 
Figure A.10: Synthetic Control Plots (Germany 1976)

(a) Wage Growth (\%)

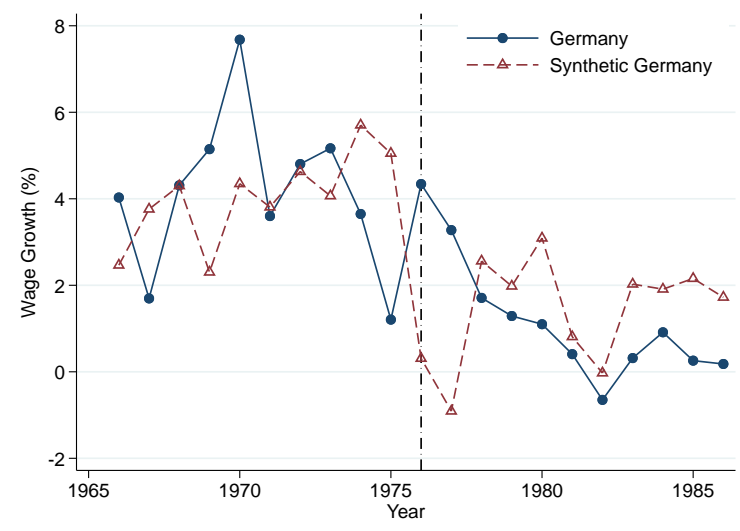

(c) Net Capital Formation (pct of GDP)

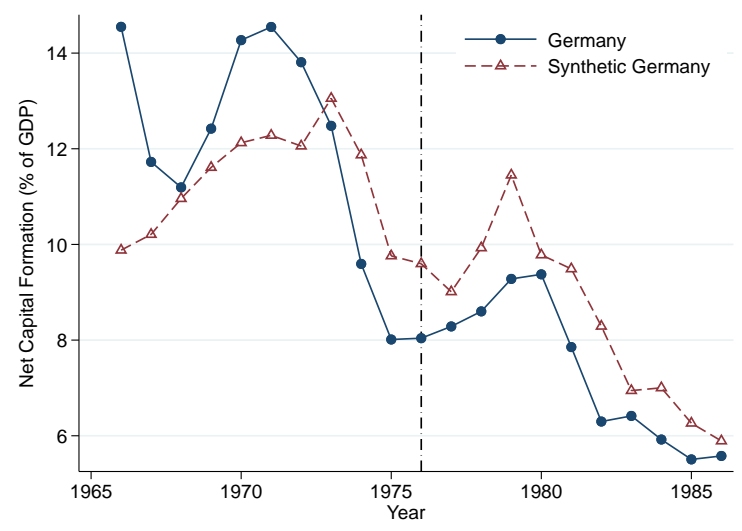

(e) GDP per Capita Growth (\%)

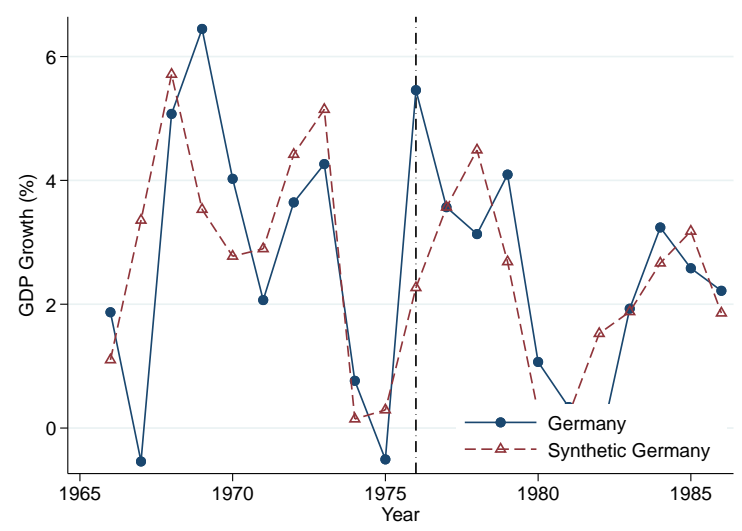

(b) Labor Share (pct)

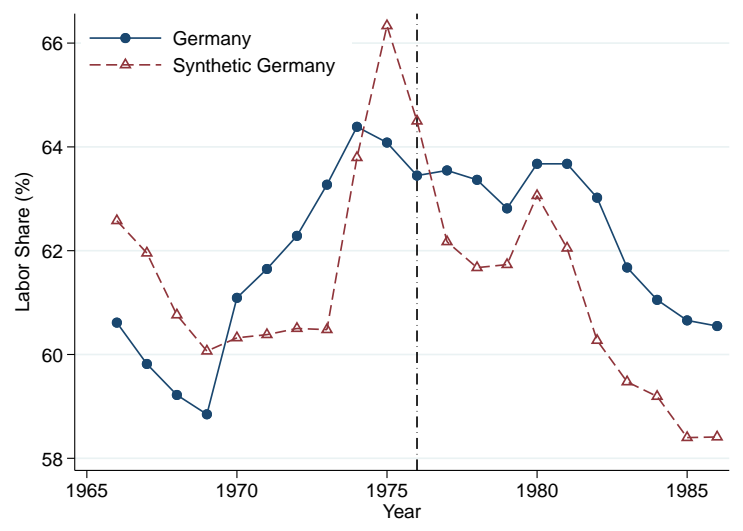

(d) TFP Growth (\%)

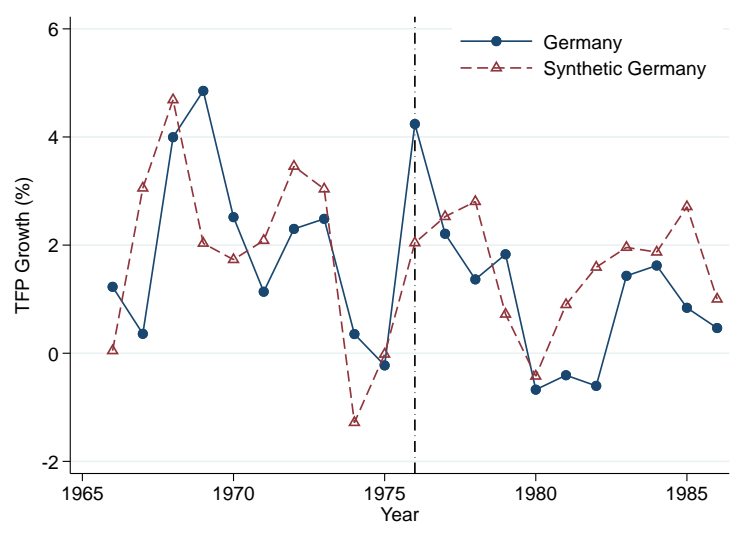

(f) Bottom 90\%'s Share of Income (\%)

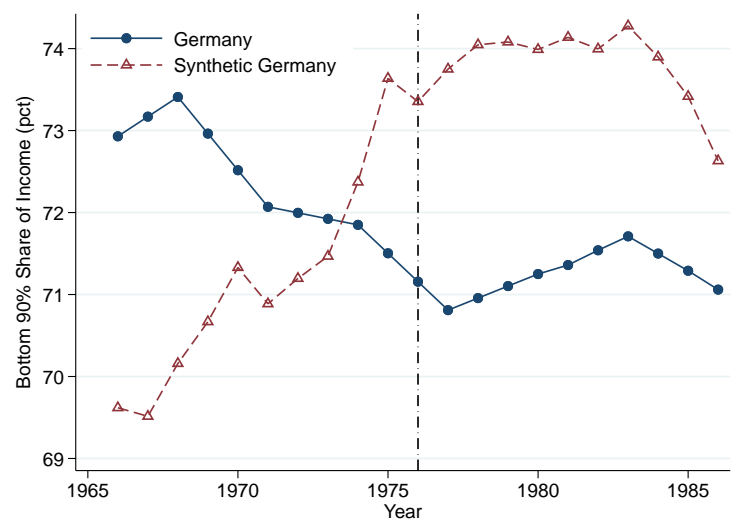

Note: For each of our dependent variables, this figure plots the raw time series in Germany (blue, solid circles) compared to its synthetic control unit (red, hollow triangles), in the 21-year period surrounding Germany's 1976 codetermination reform. 
Figure A.11: Synthetic Control Plots (Netherlands 1979)

(a) Wage Growth (\%)

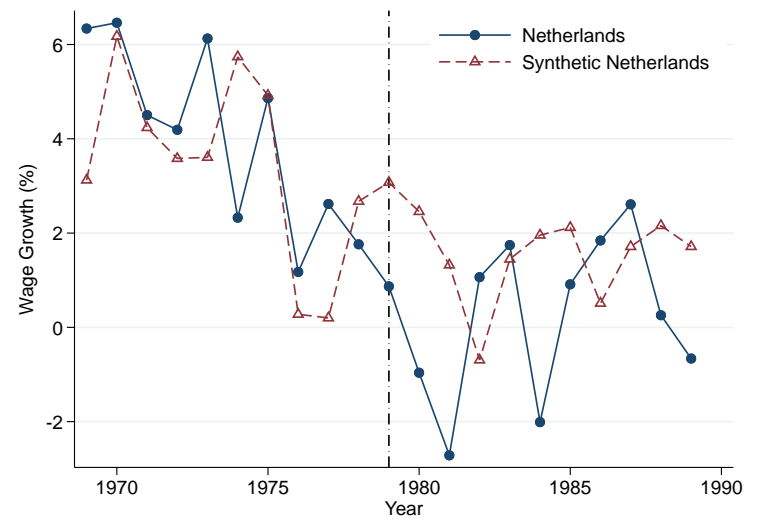

(c) Net Capital Formation (pct of GDP)

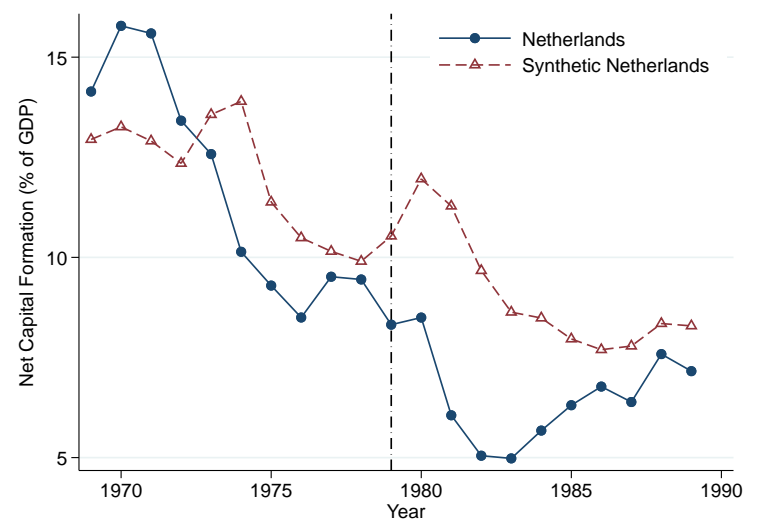

(e) GDP per Capita Growth (\%)

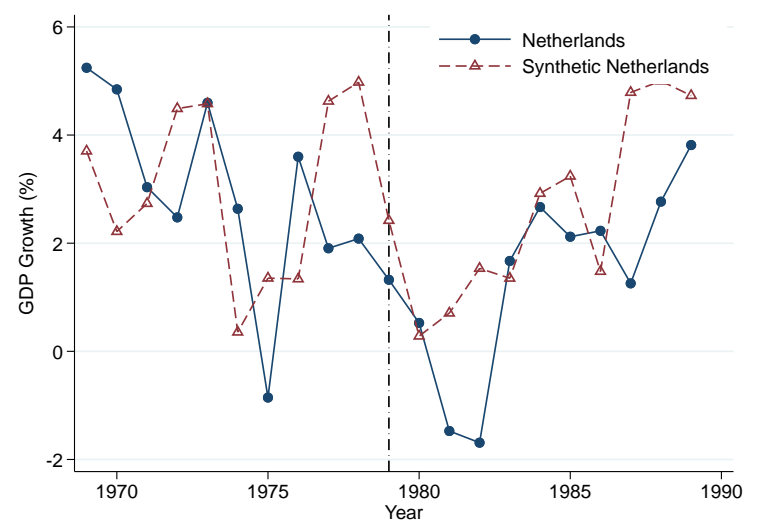

(b) Labor Share (pct)

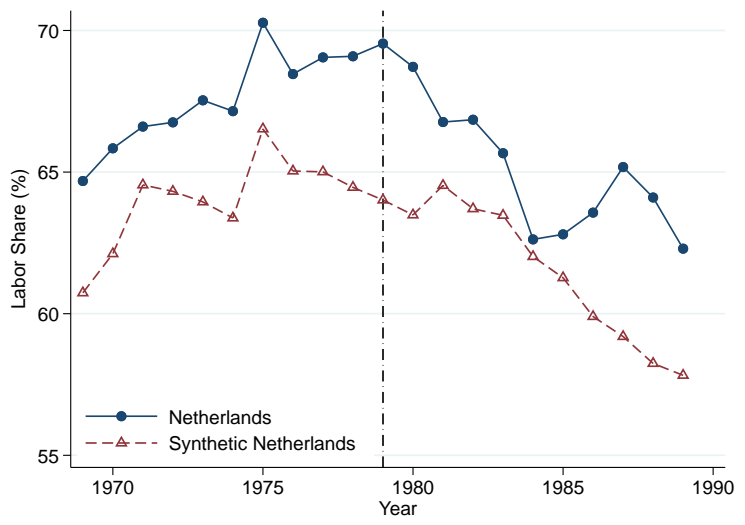

(d) TFP Growth (\%)

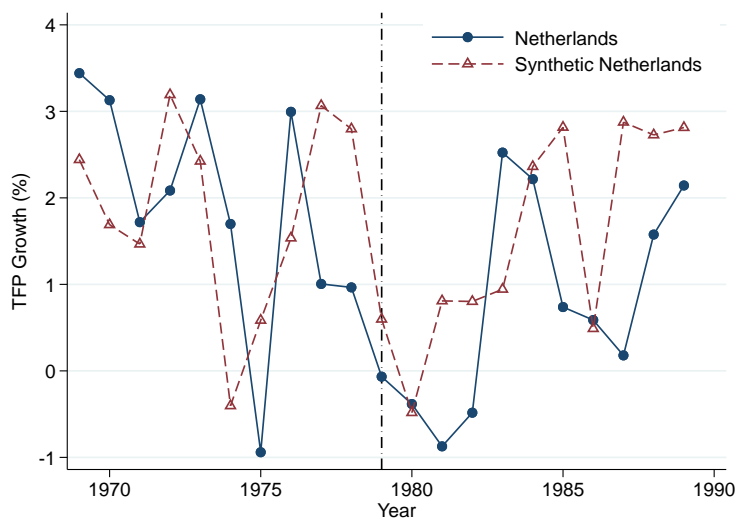

(f) Bottom 90\%'s Share of Income (\%)

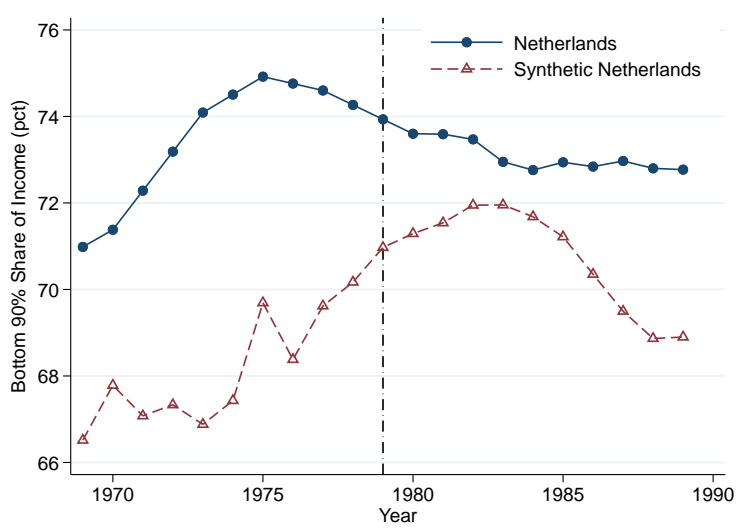

Note: For each of our dependent variables, this figure plots the raw time series in the Netherlands (blue, solid circles) compared to its synthetic control unit (red, hollow triangles), in the 21-year period surrounding the Netherlands' 1979 codetermination reform. 
Figure A.12: Synthetic Control Plots (Norway 1966)

(a) Wage Growth (\%)

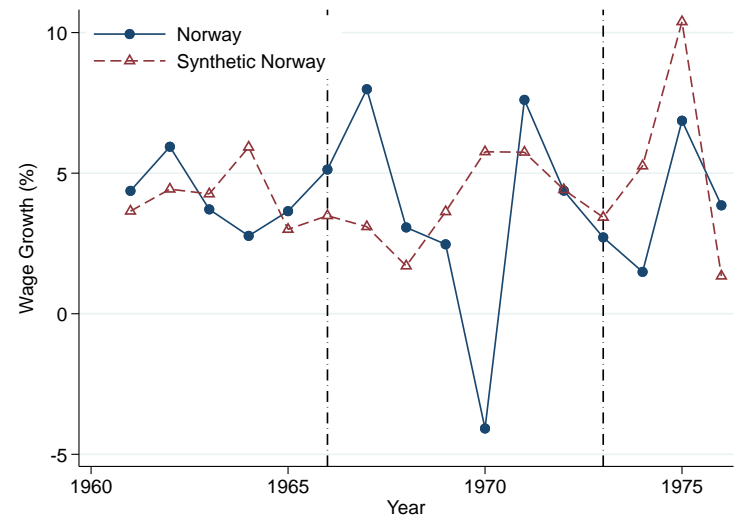

(c) Net Capital Formation (pct of GDP)

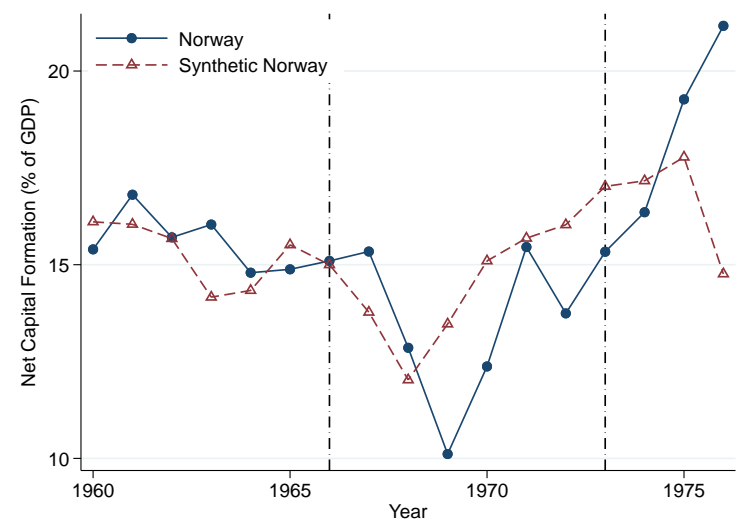

(e) GDP Growth (\%)

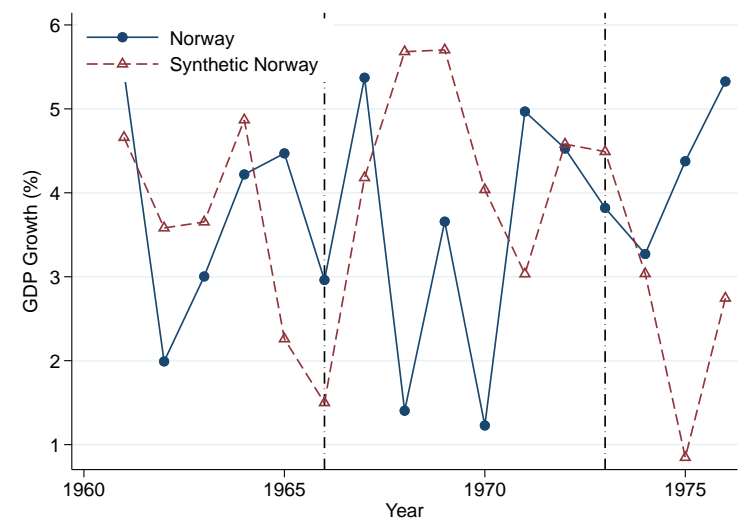

(b) Labor Share (pct)

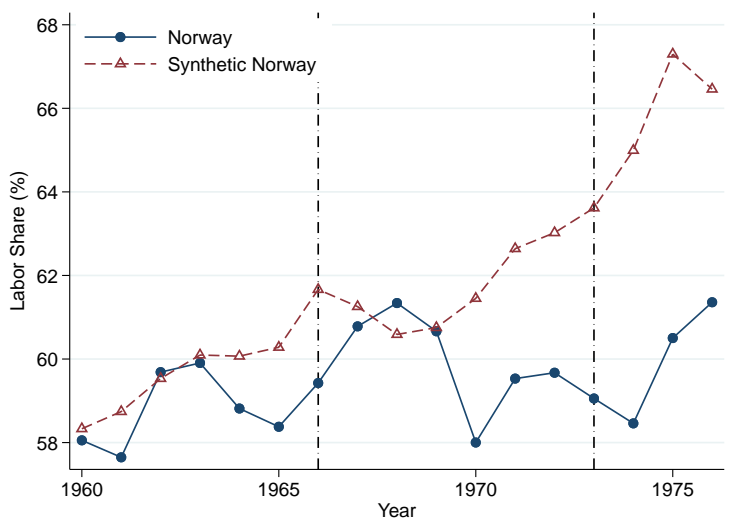

(d) TFP Growth (\%)

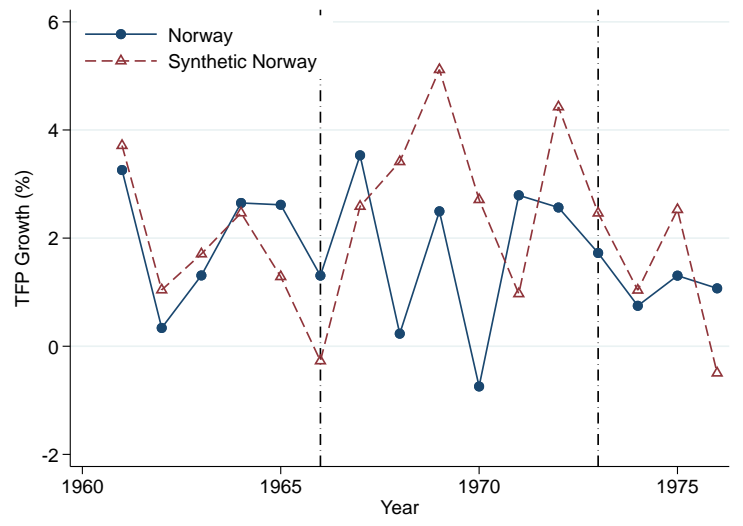

(f) Bottom 90\%'s Share of Income (\%)

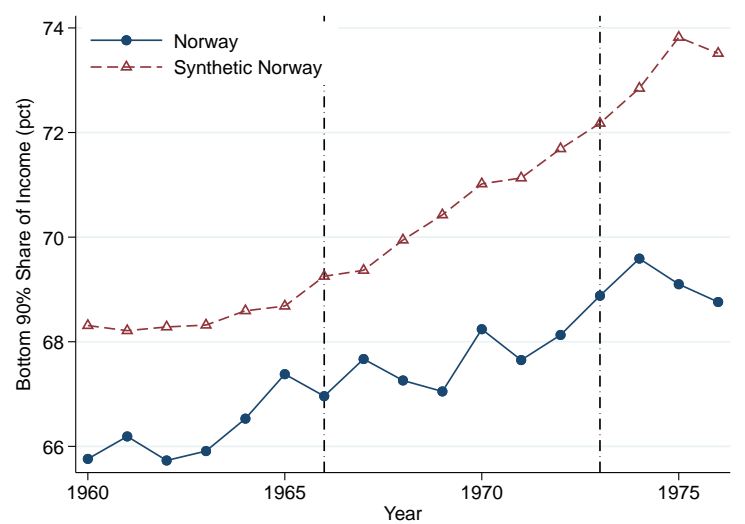

Note: For each of our dependent variables, this figure plots the raw time series in Norway (blue, solid circles) compared to its synthetic control unit (red, hollow triangles), in the 21-year period surrounding Norway's 1966 codetermination reform. 
Figure A.13: Synthetic Control Plots (Norway 1973)

(a) Wage Growth (\%)

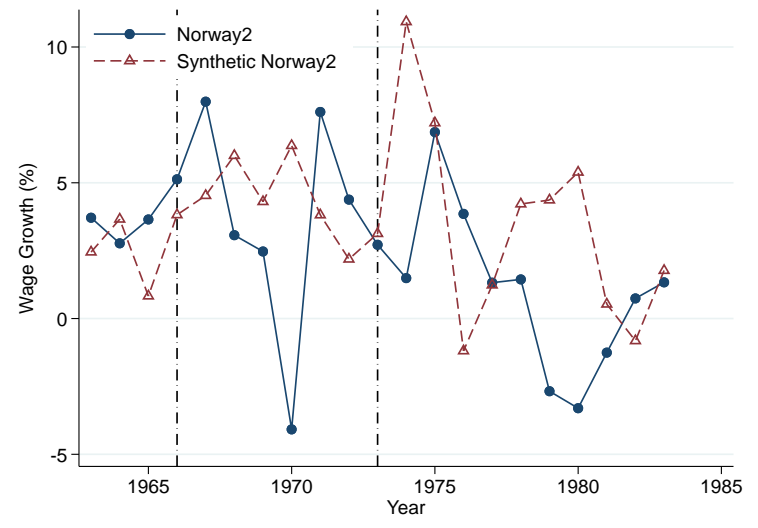

(c) Net Capital Formation (pct of GDP)

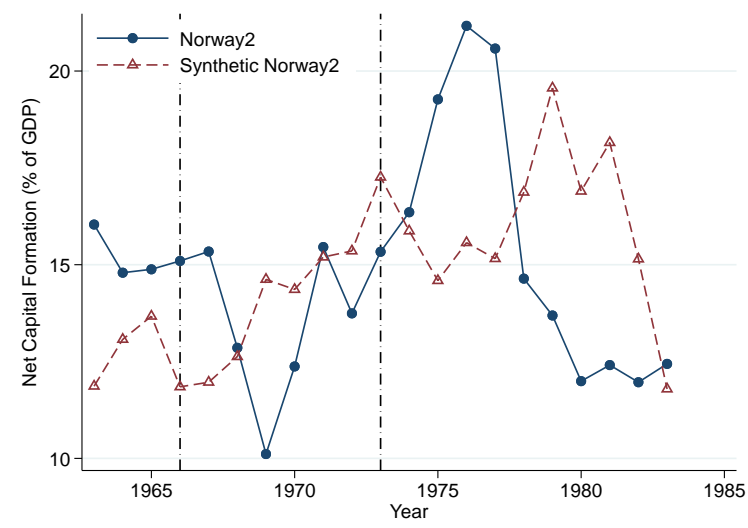

(e) GDP per Capita Growth (\%)

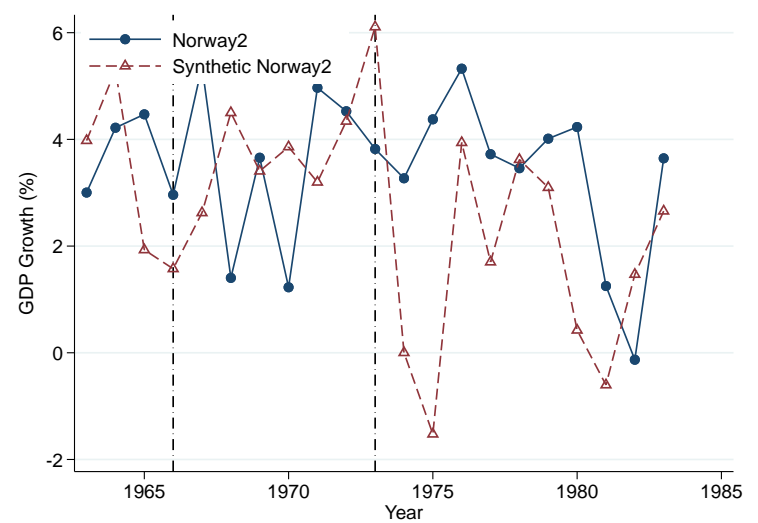

(b) Labor Share (pct)

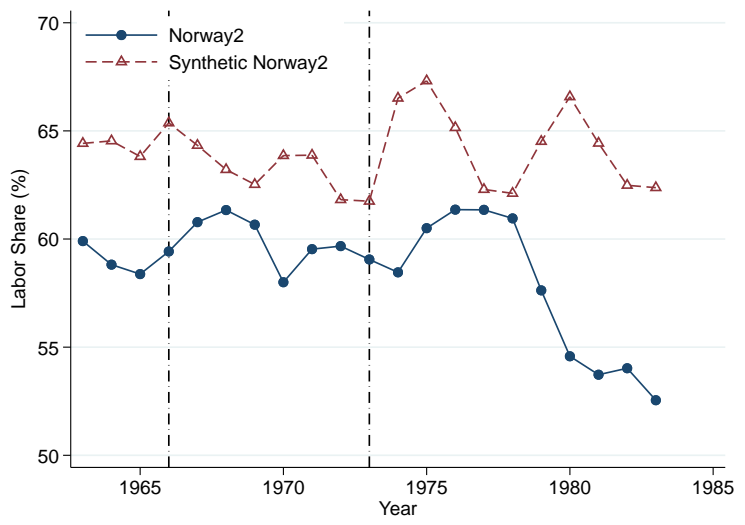

(d) TFP Growth (\%)

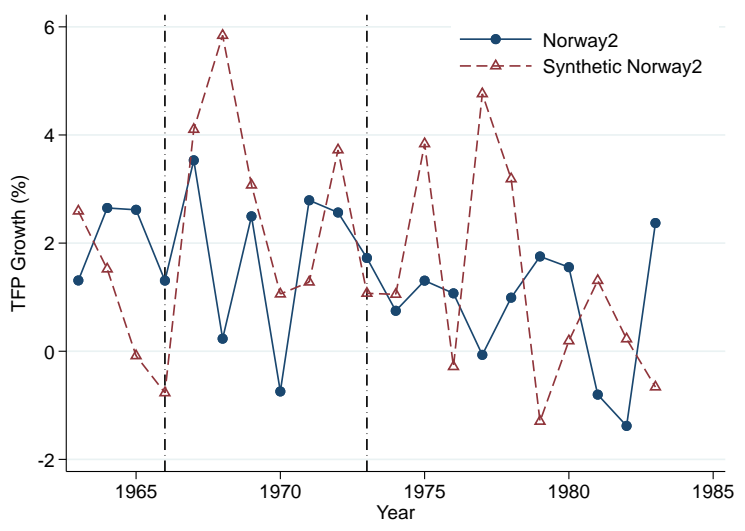

(f) Bottom 90\%'s Share of Income (\%)

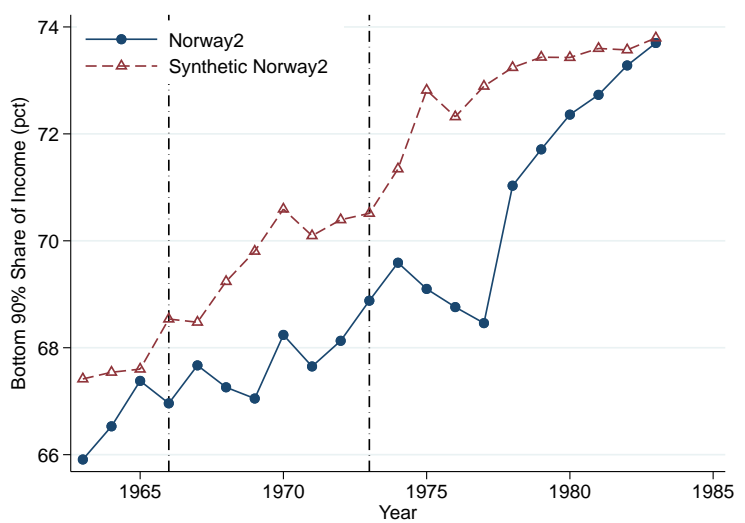

Note: For each of our dependent variables, this figure plots the raw time series in Norway (blue, solid circles) compared to its synthetic control unit (red, hollow triangles), in the 21-year period surrounding Norway's 1973 codetermination reform. 
Figure A.14: Synthetic Control Plots (Sweden 1976)

(a) Wage Growth (\%)

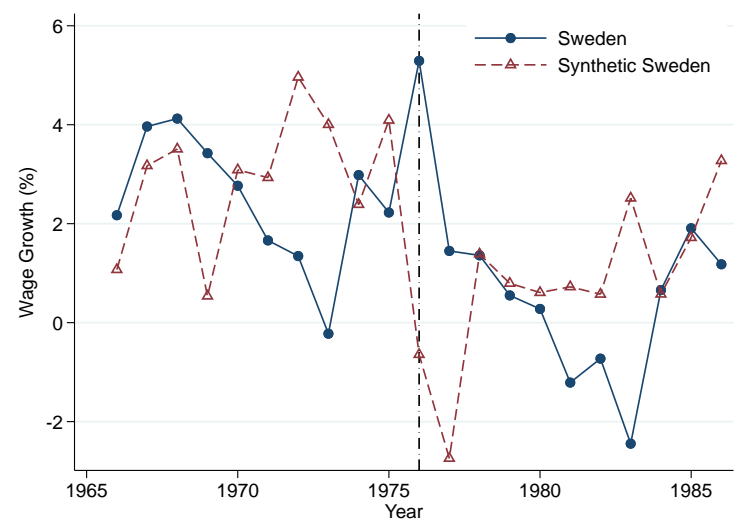

(c) Net Capital Formation (pct of GDP)

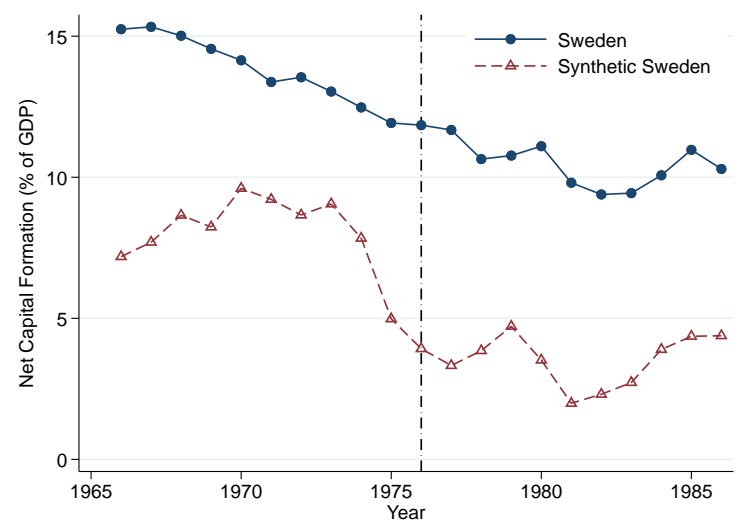

(e) GDP per Capita Growth (\%)

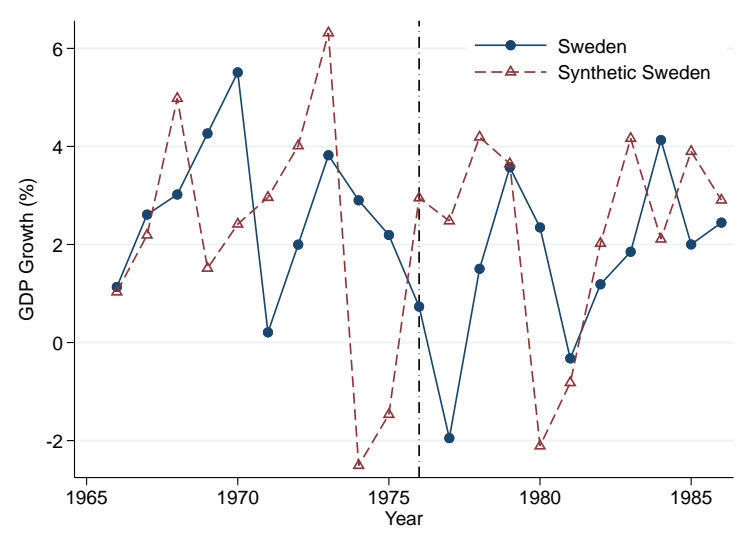

(b) Labor Share (pct)

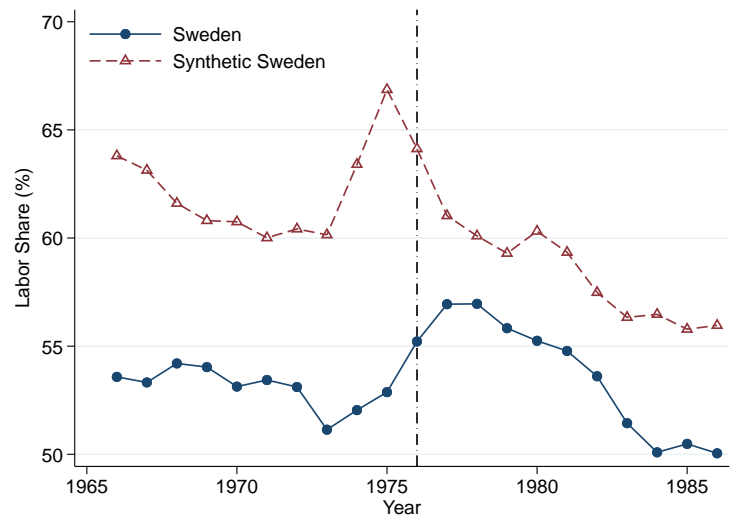

(d) TFP Growth (\%)

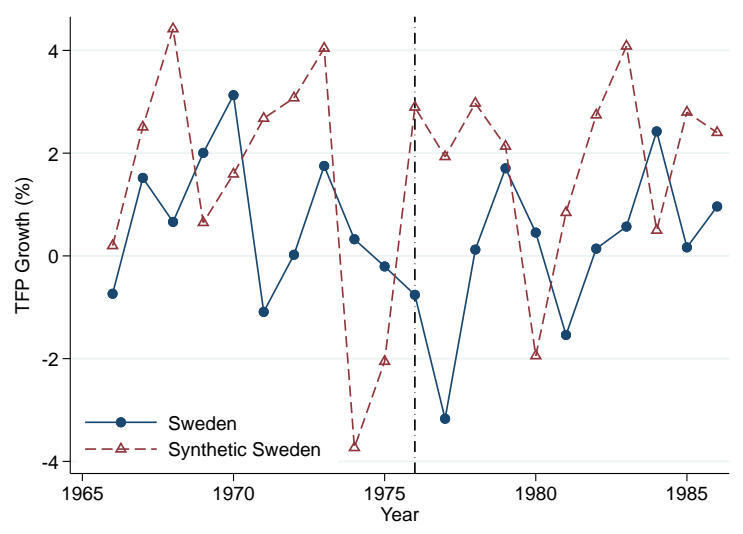

(f) Bottom 90\%'s Share of Income (\%)

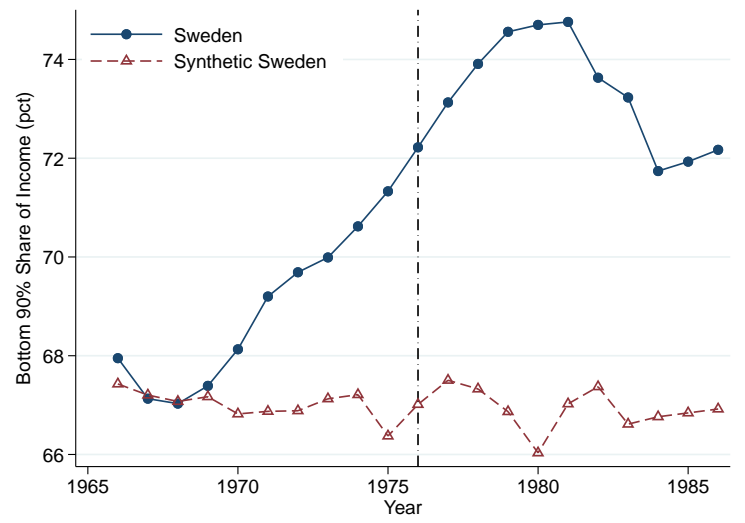

Note: For each of our dependent variables, this figure plots the raw time series in Sweden (blue, solid circles) compared to its synthetic control unit (red, hollow triangles), in the 21-year period surrounding Sweden's 1976 codetermination reform. 
Figure A.15: Worker Influence in Other Areas (2019 ECS)

(a) Dismissals

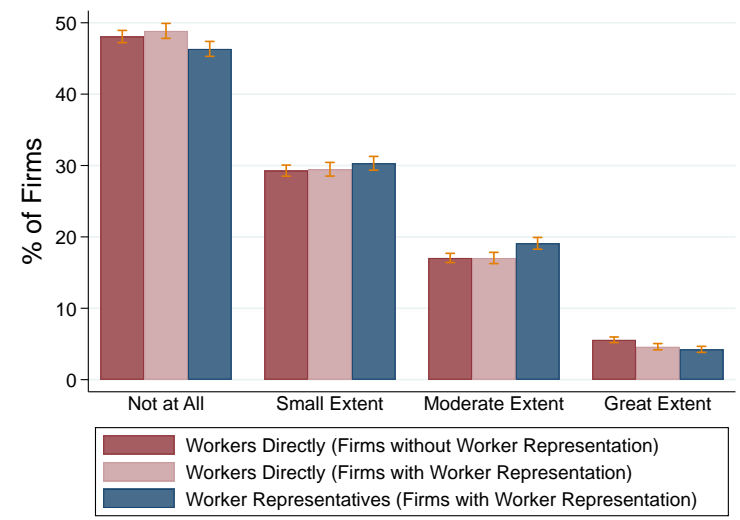

(c) Working Time Arrangements

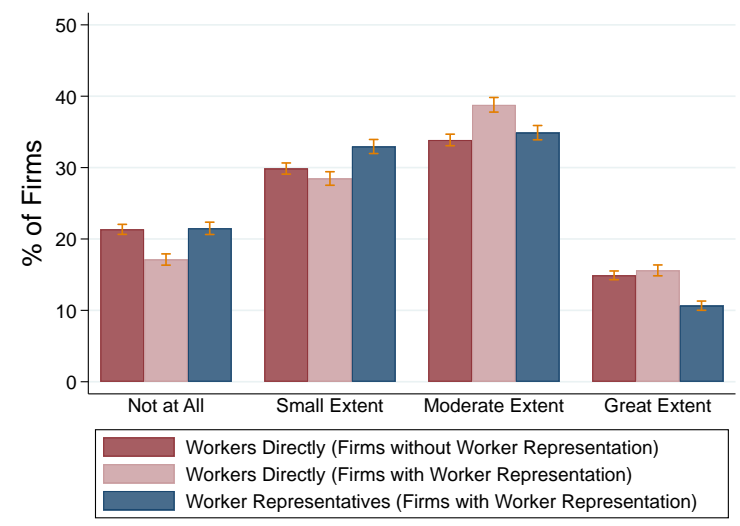

(b) Training

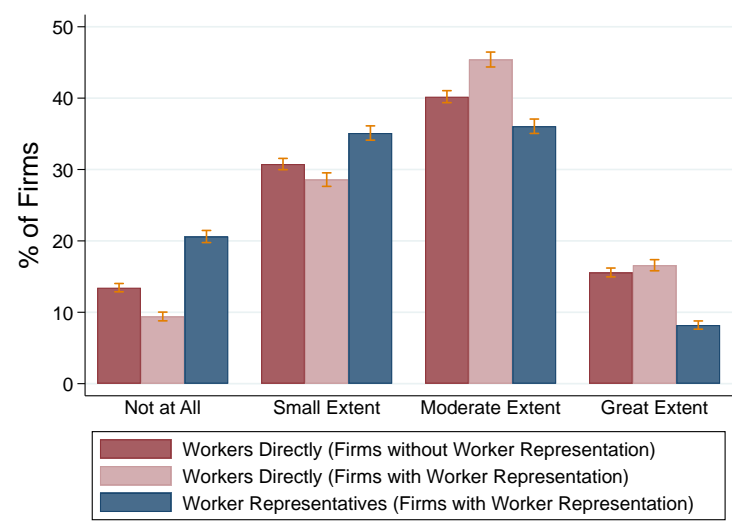

(d) Payment Schemes

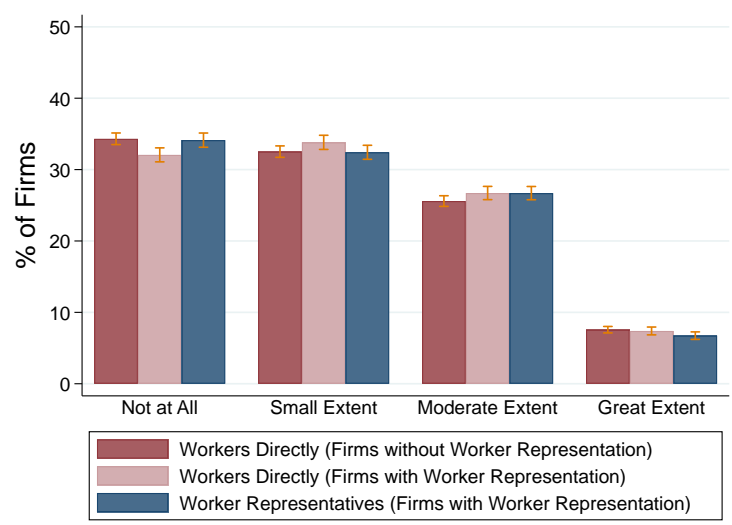

Note: Panel (b) of Figure 5 plots responses to a 2019 European Company Survey question about workers' influence on decisions regarding workplace organization. The same question is also asked about workers' influence in four other areas: dismissals, training, working time arrangements, and payment schemes. The four panels of this Figure plot the responses for those four areas. 


\section{B Event Studies: Data and Empirical Methodology}

\section{B.1 Sample Construction and Identifying Codetermination Reforms}

In our main event study analyses, we restrict our attention to countries satisfying the following criteria:

- They are European (since our paper studies European codetermination in particular).

- We have non-missing data for at least some of our outcome variables for the period 1960-2019 (notably, this excludes former Soviet Bloc countries, for whom we lack data before the 1990s; it also excludes Cyprus and Malta, whose macroeconomic data series are not available until the 1990s).

- They are democracies across the entire period we study (this excludes Portugal, Spain, Greece, and Turkey).

We also exclude Luxembourg because we consider it to be economically unrepresentative. Imposing these restrictions leaves us with the following countries: Austria, Belgium, Denmark, Finland, France, Germany, Iceland, Ireland, Italy, the Netherlands, Norway, Sweden, Switzerland, and the United Kingdom. As we describe in Section B.6, we further narrow down our sample when analyzing our "income inequality" outcome variable.

Next, among these countries, we identify reforms that introduced or extended codetermination (either legislatively or through collective agreements). To search for codetermination reforms, we begin by examining all changes in the "codetermination" variables in the CBR Labor Regulation Index historical dataset (Adams, Bishop, and Deakin, 2016), and supplement this with detailed country-by-country internet searches. Based on this searching and qualitative evaluations of the "substantiveness" of reforms, we narrow down to the list of codetermination reforms visualized in Figure A.16

Institutional details of these reforms are summarized in Table A.1. We exclude from this list several reforms which we do not consider to be substantive introductions or extensions of codetermination; these excluded reforms, and our reasons for excluding them, are summarized in Table A.2. Broadly speaking, reforms that we consider "non-substantive" include reforms that involved only procedural updates or minor extensions of existing codetermination arrangements (e.g., in Germany in 2004; Page, 2018), reforms that created "worker representation" institutions lacking real co-decision-making rights, and several reforms with low take-up (e.g., in Greece and Italy). 
Figure A.16: Codetermination Reforms

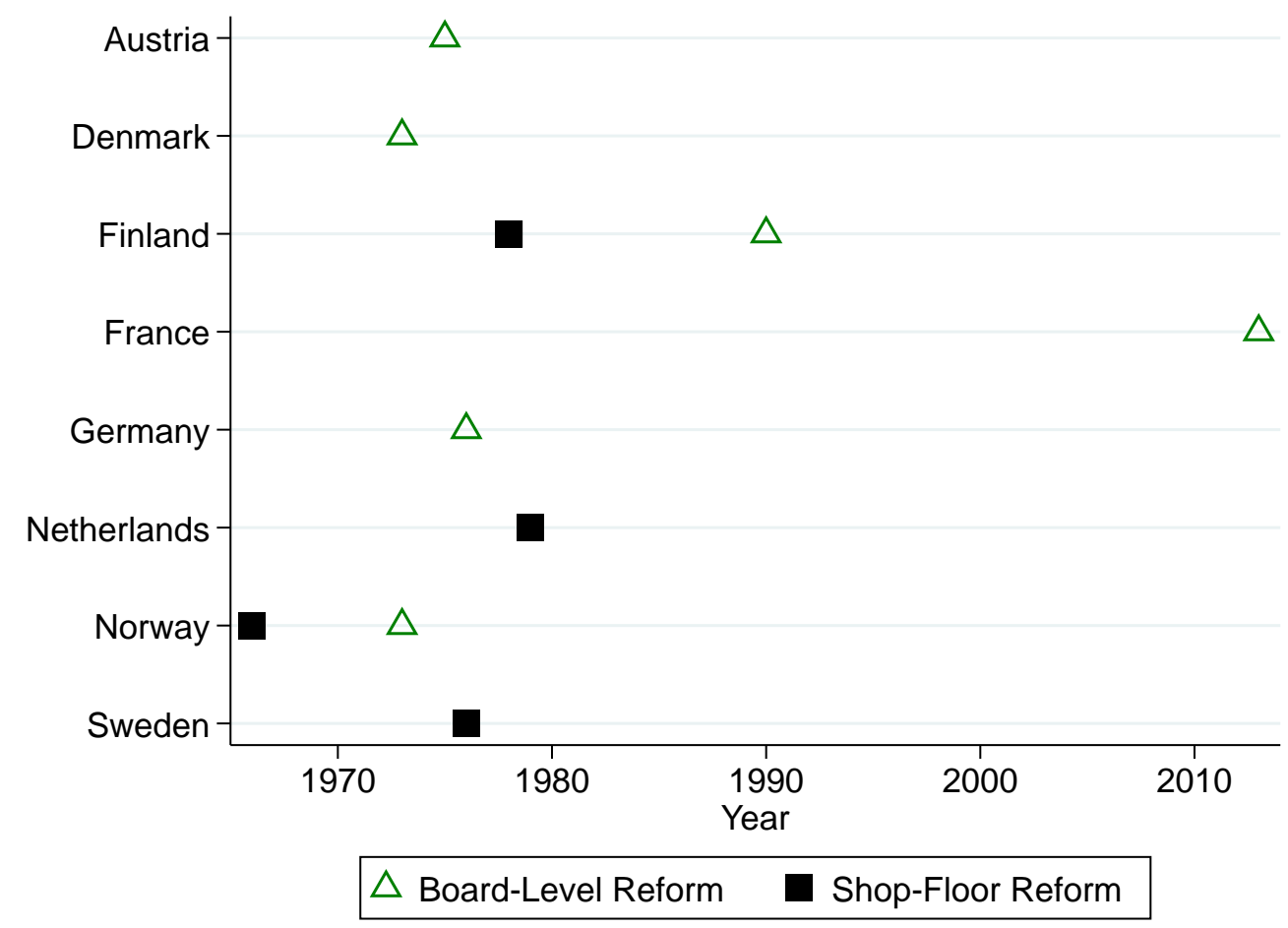

Table A.1: Institutional Details of Codetermination Reforms

\begin{tabular}{|c|c|}
\hline Country & Description of Reform and Institutional Background \\
\hline \multirow[t]{2}{*}{ Austria (1975) } & $\begin{array}{l}\text { The Labour Constitution Act } 1975 \text { introduced one-third board-level } \\
\text { representation in firms with } 40 \text { or more workers, and gave works } \\
\text { councils the power to nominate these representatives (Adams, Bishop, } \\
\text { and Deakin, 2016; ETUI, 2020). }\end{array}$ \\
\hline & $\begin{array}{l}\text { Works councils in Austria have existed since the Works Council Act } \\
\text { of 1919, and have had extensive shop-floor codetermination powers } \\
\text { since then (Adler. 1922). Their powers were slightly extended and } \\
\text { clarified in the } 1975 \text { Labour Constitution Act, but the introduction } \\
\text { of board-level representation was the Act's primary expansion of } \\
\text { codetermination. }\end{array}$ \\
\hline
\end{tabular}

Continued on next page 
Table A.1—continued from previous page

Country Description of Reform and Institutional Background

Denmark (1973)

The Danish Companies Act 1973 introduced one-third board-level representation rights in firms with 35 or more employees. Take-up of this right has been moderate-to-high; about $55 \%$ of Danish workers are employed in a company with board-level representation (ETUI, 2020).

Shop-floor representation has existed in Denmark since the early 1900s, through large-scale collective agreements between unions and employer associations. An agreement in 1900 established official shop stewards, and an agreement in 1947 established co-operation committees (similar to works councils). Denmark had no official legislation on shop-floor representation until 2005, when an EU Directive required the introduction of legislation (Knudsen, 2006).

Finland $(1978,1990)$

A 1978 Cooperation Act introduced shop-floor representation rights in firms with 30 or more employees. In addition, a 1990 Act established board-level representation rights in firms with 150 or more employees. These reforms are both substantive, so we study each of them separately. Take-up of shop-floor representation is very high, while take-up of board-level representation has been moderate (Harju, Jäger, and Schoefer, 2021).

Prior to 1978, codetermination did not really exist in Finland, though there was high collective bargaining coverage and high union density. Finnish unions were powerful, but favored adversarial bargaining and negotiation over codetermination. During the economic disruptions of the 1960s and 1970s, Finnish unions changed their minds and began advocating for industrial democracy. Their lobbying efforts culminated in the 1978 Cooperation Act (Sippola, 2012).

Continued on next page 
Table A.1—continued from previous page

Country

France (2013)

\section{Description of Reform and Institutional Background}

A 2013 reform introduced mandatory board-level worker representation in share-based firms with 5,000 or more workers, a threshold that was lowered to 1,000 in 2015. Data from a top group of French companies indicates that the reform had substantial bite. Prior to 2013, only state-owned or formerly state-owned French companies tended to have board-level worker representation (ETUI, 2020).

France has had mandatory shop-floor representation in firms with 50 or more workers since 1945. The Auroux Laws of 1982 slightly extended the rights of shop-floor representatives and clarified their ability to coexist with establishment-level union representation, but did not substantially increase the strength of shop-floor representation (Fairris and Ashkenazy, 2010). 
Table A.1—continued from previous page

\begin{tabular}{ll} 
Country & Description of Reform and Institutional Background \\
\hline Germany (1976) & The 1976 Mitbestimmungsgesetz increased the board-level represen- \\
tation requirements for firms with more than 2,000 employees not \\
in the iron, coal, or steel sectors from one-third to quasi-parity rep- \\
resentation. This was a major change that was heavily opposed by \\
employer associations, and the evidence indicates that quasi-parity \\
board-level representation is a significantly stronger institution than \\
one-third board-level representation. In addition, our calculations \\
from Bureau van Dijk data indicate that more than 30\% of German \\
workers are employed in firms with more than 2,000 workers, so this \\
reform had substantial coverage. \\
Board-level representation requirements were originally introduced \\
in Germany in 1952, with firms in the mining, coal, and steel sectors \\
required to adopt parity representation, and firms with over 500 \\
employees in other sectors required to adopt one-third represen- \\
tation. There were minor updates to the one-third representation \\
requirements in 1972 and 2004, but neither of these were substantive \\
reforms (Autenrieth, 2004). \\
Shop-floor representation in Germany has a long history dating \\
back to the early 1900s. The pre-Nazi works council system was \\
re-established in Germany in 1946 by the occupying powers, but \\
works councils were voluntary and had no co-decision-making \\
powers. In 1952, the Works Constitution Act mandated works \\
councils in establishments with 5 or more employees, and gave them \\
co-decision-making rights. This reform is too early for us to study \\
given our data. A 1972 Act "expanded the coverage and duties of \\
works' councils," but was not a particularly substantive extension of \\
shop-floor representation (Havlovic., 1990). \\
\end{tabular}

Continued on next page 
Table A.1—continued from previous page

Country

Netherlands (1979)
Description of Reform and Institutional Background

A 1979 amendment to the Works Councils Act gave previously toothless Dutch works councils much broader scope and powers.

Prior to the 1950s, the Netherlands had an extensive union presence but no codetermination. In the post-war reconstruction of the 1950s, workers began advocating for co-decision-making rights. In 1950, the Dutch Works Council Act required all establishments with 50 or more workers to set up a works council. However, the works councils were chaired by managers, and had only information and discussion rights, without co-decision-making powers. In 1979, the Act underwent a huge amendment, which removed managers from the works councils, broadened the works councils' scope, gave works councils consultation rights on all major decisions, and gave them a right to appeal to an employment court if the employer did not follow their advice (Van het Kaar, 1997).

The Netherlands has also technically had one-third board-level representation rights since 2004, but the rights are not substantive. As Van het Kaar (2007) writes:

[...] because the individuals nominated by the works council may not be employees or trade union officials dealing with the company, they are in no sense direct representatives of the workforce. Dutch law requires all supervisory board members to act in the interests of the company as a whole; individual supervisory board members may not represent specific interests, such as the workforce or a major shareholder. 
Table A.1—continued from previous page

Country Description of Reform and Institutional Background

Norway $(1966,1973)$ A 1966 Co-operation Agreement between union associations and employer associations mandated works councils in establishments with 100 or more employees, and gave those councils information and consultation rights. In addition, the Limited Liability Companies Act 1973 introduced one-third board-level representation rights in firms with 30 or more employees.

Codetermination in Norway originated with a 1945 collective agreement establishing joint consultation committees; this was followed up by a 1957 agreement strengthening the rights of shop-floor union representatives, and the 1966 agreement, which significantly expanded shop-floor representation by establishing works councils (Bjorheim, 1974).

Continued on next page 
Table A.1—continued from previous page

Country
Sweden (1976) The 1976 Co-determination Act gave Swedish unions ext Reform and Institutional Background
sive consultation, negotiation, and co-decision-making pow
Establishment-level union representation is the primary chan
for codetermination in Sweden; although the country also has bo
level representation (introduced by a 1973 law) and works cou
representation, these institutions are secondary to the primary
tution of codetermination through union representation. As An
Victorin writes:
[Neither board-level representation nor works councils]
form the focal point of the Swedish system of industrial
democracy [...] The Swedish system is rather based on
negotiations, information and collective bargaining. [...]
[Through the Co-determination Act] the employer has
extensive duties to inform the trade unions with which he
has a collective relationship [...] it is in such negotiation
that important conflicts [...] are to be resolved, not board
meetings. (Victorin, 2000, p.4)
Board representation in Sweden represents a side-track
in the development of industrial democracy [...] the
unions look upon minority board representation more
as a means of gaining information than as a means of
exercising substantive influence on the decisions of a
company. (Victorin, 1979, p.117)

In Table A.2, we describe European codetermination "reforms" that occur in our sample countries between 1960 and 2019 and that we exclude because we do not believe they constitute substantive introductions or extensions of codetermination. 


\begin{tabular}{|c|c|}
\hline Country & Description of Reform and Institutional Background \\
\hline France (1982) & Excluded for reasons described in the "France" entry of Table A.1. \\
\hline Germany $(1972,2004)$ & $\begin{array}{l}\text { Excluded for reasons described in the "Germany" entry of Table } \\
\text { A.1. }\end{array}$ \\
\hline Greece $(1988,1990)$ & $\begin{array}{l}\text { Two Greek reforms in } 1988 \text { and } 1990 \text { established rights to form } \\
\text { works councils, and Greece was democratic for a 10-year period } \\
\text { preceding the } 1988 \text { reform, so we could include Greece as a treated } \\
\text { country in our analyses despite excluding undemocratic countries } \\
\text { from our sample. However, take-up of the right to form a works } \\
\text { council has been virtually nonexistent due to a lack of enthusiasm } \\
\text { on the part of both employers and workers-fewer than } 2 \% \text { of } \\
\text { workplaces have an established works council (Carley, Baradel, and } \\
\text { Welz, 2005). We therefore exclude the Greek reform, since it has } \\
\text { not had any bite. }\end{array}$ \\
\hline Italy (1970) & $\begin{array}{l}\text { The } 1970 \text { Workers' Statute gave unions the right to form shop- } \\
\text { floor representative bodies; this right was extended by collective } \\
\text { agreements in } 1993 \text { and } 2014 \text { (ETUI, 2020). However, these bodies } \\
\text { lack substantive codetermination rights and the real worker power } \\
\text { in Italian workplaces lies with unions, through collective bargaining } \\
\text { and adversarial negotiations (Degrauwe et al., 2018). }\end{array}$ \\
\hline Luxembourg (1974) & $\begin{array}{l}\text { Luxembourg introduced board-level and shop-floor representation } \\
\text { laws in 1974, but we exclude it from our analysis because of its } \\
\text { economic unrepresentativeness. }\end{array}$ \\
\hline Netherlands (2004) & $\begin{array}{l}\text { Excluded for reasons described in the "Netherlands" entry of Table } \\
\text { A.1. }\end{array}$ \\
\hline
\end{tabular}

\section{B.2 Strikes Data}

Our data on strikes and work stoppages are drawn from the International Labour Organization's (ILO's) Yearbooks of Labour Statistics, which have been published annually since 1936. We thank Sjaak van der Velden for sharing compiled and digitized versions of these data with us. The data are only available until 2008, so the 2013 French reform is excluded from our analysis 
of strikes.

The ILO collects data on strikes from national statistical agencies, and strives to make these data as consistent as possible across countries, though some cross-country inconsistencies remain (for example, there is some variation in the criteria for a strike to be recorded).

The main variable we draw on is the "number of working days lost" to strikes and work stoppages. We apply a pair of transformations to this variable. First, we normalize it by the size of the country's working-age population in that year, using World Bank population data.8 Next, we transform it into an ordinal variable. The motivation for this is that the cardinal values of the variable are extremely volatile, with massive outliers. For example, consider the raw time series for Germany, plotted in Panel (a) of Figure A.17. The variable is so volatile that even log transformations or winsorizations are insufficient to prevent outlier values from driving results.

To transform from a cardinal strikes variable to an ordinal one, we use the following procedure. Within each country, we rank all years with nonmissing strikes data according to the cardinal "working days lost divided by working-age population" variable. We divide this rank by the number of years with nonmissing strikes data, to yield a variable that ranges between 0 and 1 . A value of 0 represents the year with the lowest strike intensity 9 and a value of 1 represents the year with the highest strike intensity. We use this 0 -to- 1 rank variable as the outcome variable in our event study specifications, so our specifications effectively test whether the years following a codetermination reform are ranked lower or higher in terms of strike intensity than the years preceding a codetermination reform. As Panel (b) of Figure A.17illustrates by plotting the time series of Germany's strike intensity rank, the strike rank variable is still fairly volatile but does not have large cardinal outliers that could singlehandedly drive our results.

${ }^{8}$ World Bank population data is only available back to 1960, so prior to 1960 we use total population data from the ILO, which we have in roughly 10-15 year intervals. We linearly interpolate the ILO variable between the years for which we have values, and multiply it by the percentage of the population who are working-age in 1960 in the World Bank data.

${ }^{9} \mathrm{~A}$ value of exactly 0 can only be reached as $t \rightarrow \infty$. 
Figure A.17: Germany Strikes Time Series

(a) Cardinal Strike Intensity

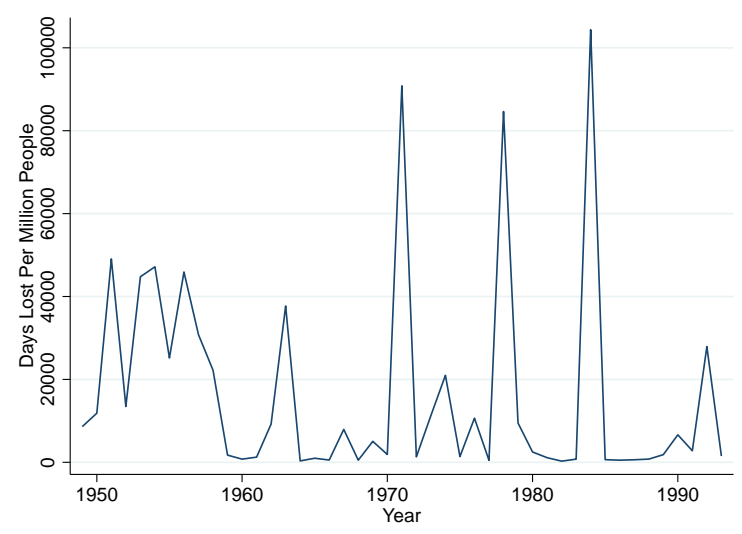

(b) Strike Intensity Rank

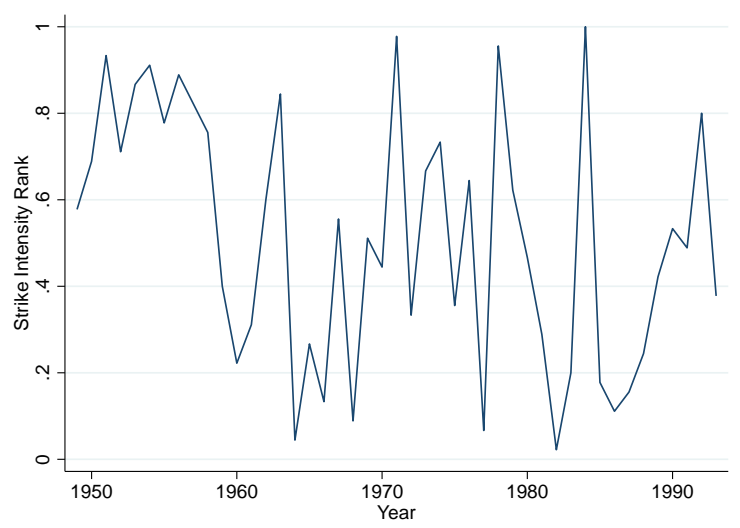

\section{B.3 Cooperative Industrial Relations Data}

To measure cross-country differences in the cooperativeness of industrial relations, we draw on an item in the World Economic Forum's Executive Opinion Survey. Conducted annually in about 140 countries, the Executive Opinion Survey contains the following question, with responses on a 1-7 scale:

In your country, how do you characterize labor-employer relations?

\begin{tabular}{lll|l|l|l|l|l|l} 
Generally confrontational & 1 & 2 & 3 & 4 & 5 & 6 & 7 & Generally cooperative
\end{tabular}

Country-level averages from the Executive Opinion Survey are published biannually in the World Economic Forum's Global Competitiveness Report; we have access to this data biannually since the 2007-2008 Report.

Figure A.18 maps the average cooperativeness of labor relations in each country in 2015 (the year we use for calculating the correlation between cooperativeness and codetermination laws, since our data on codetermination laws from the CBR Labor Regulation Index ends in 2015). 
Figure A.18: Cooperativeness of Industrial Relations (2015)

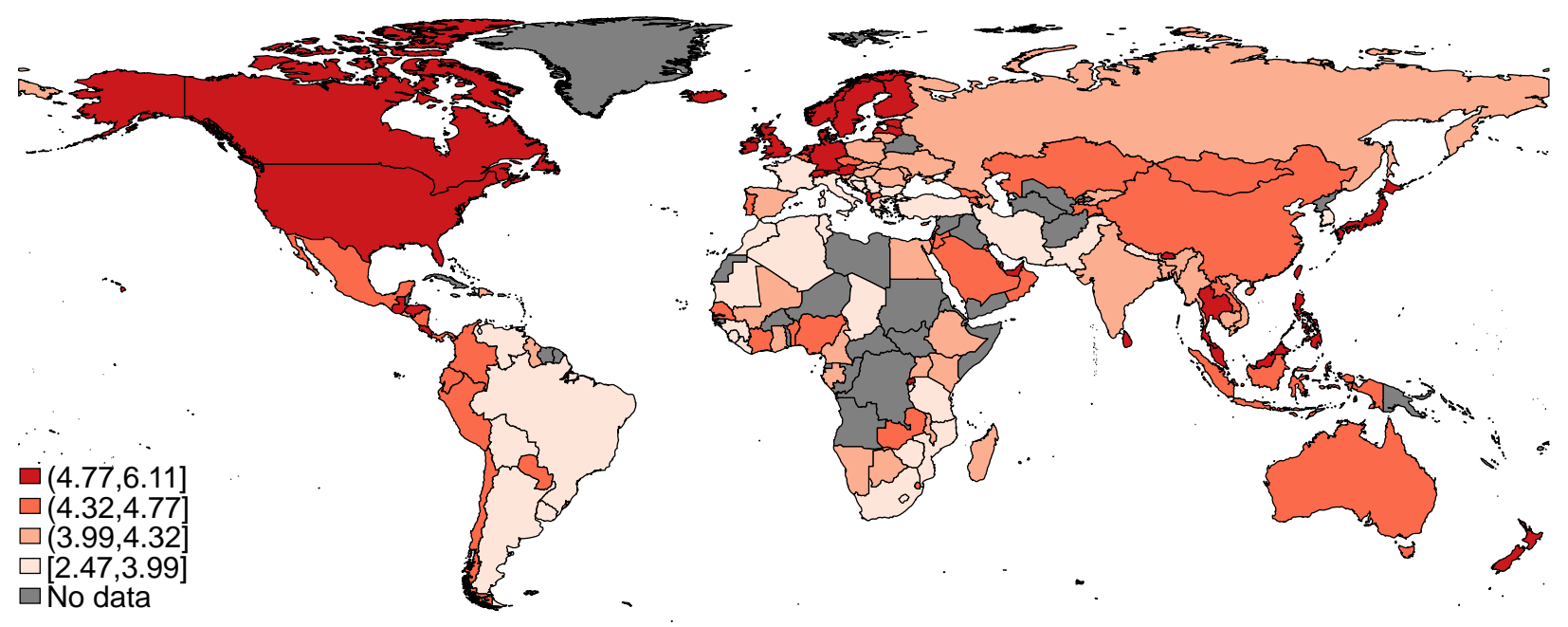

\section{B.4 Union Density Data}

Our data on union density are drawn from the OECD/IAIS dataset compiled by Visser (2021), which contains information about union density at the country-year level for all countries in our sample except Iceland extending back to 1960. "Union density" is defined as the percentage of a country's workers who belong to a union. Many of the countries in our sample are missing union density information for a small number of years between 1960 and 2019; we fill in these gaps using linear interpolations of the variable.

\section{B.5 Macroeconomic Data}

Our aggregate economic variables (wage growth, the labor share, net capital formation, and total factor productivity) are drawn from the European Commission's AMECO Database, which contains macroeconomic statistics at the country-year level for European Union and some OECD countries since 1960. All currency amounts in the database are presented in Euros. The variables we use are defined as follows:

- Wage growth in year $t$ is the percentage growth in average real wages in year $t$ compared to year $t-1$, i.e. $100 \times\left(w_{t}-w_{t-1}\right) / w_{t-1}$ if we let $w_{t}$ denote average wages in year $t$.

- The labor share is total compensation of employees as a percentage of GDP.

- Net capital formation is net formation of fixed capital as a percentage of GDP.

- TFP growth is the percentage growth in total factor productivity in year $t$ compared to year $t-1$, defined identically to growth in real wages. 
- GDP growth is the percentage growth in GDP per capita in year $t$ compared to year $t-1$, defined identically to growth in real wages.

We choose to specify our wage, TFP, and GDP variables in terms of growth rates rather than levels for reasons explained in Footnote 5 .

\section{B.6 Income Inequality Data}

Our data on income inequality are drawn from the World Inequality Database. We draw on the most extensively available measure of income inequality in the database, which is the share of a country's national income held by the bottom $90 \%$, where the population consists of equal-split adults.

Data back to 1960 are available only for some of the countries in our main sample: Denmark, France, Germany, the Netherlands, Norway, Sweden, Switzerland, and the United Kingdom, covering 7 of our 10 codetermination reforms. In our analyses of income inequality, we restrict to these countries, and add the Australia, Canada, and the United States as additional comparison countries to compensate for our loss of countries.

\section{B.7 Empirical Methodology}

\section{B.7.1 Constructing Synthetic Control Groups}

For each country-reform and each outcome variable, we construct a synthetic control group using the following procedure. For ease of exposition, suppose we are constructing a synthetic control group for Austria's 1975 reform, for the wage growth variable.

We begin by identifying all other countries in our sample that do not experience a codetermination reform between 1965 (10 years pre-reform) and 1985 (10 years post-reform). Recall that, as described in Appendix Section B.1. our sample consists of European countries that were independent and democratic from 1960-2019 and that have non-missing macroeconomic data for most of that period (Austria, Belgium, Denmark, Finland, France, Germany, Iceland, Ireland, Italy, the Netherlands, Norway, Sweden, Switzerland, and the United Kingdom).

Notably, the pool of comparison countries for Austria includes both countries that never have codetermination laws across this 21-year period, and countries that always have codetermination laws over this period but do not experirence a reform in this period. In the case of the 1975 Austrian reform, the comparison countries are the United Kingdom, Italy, and Ireland (which never have codetermination), as well as Belgium (which has shop-floor representation from 1948 onwards; Hurley, 1953) and France (which has shop-floor representation from 1945 onwards, and does not have board-level representation until 2013 - see Appendix Table A.1. Iceland is not included because its data on wage growth start only in 1970, halfway through the pre-treatment period. 
We select synthetic control weights for the comparison countries by matching on the pre-reform levels of the following aggregate outcome variables: wage growth, the labor share, net capital formation, TFP growth, and GDP growth (i.e., exactly the outcome variables we study). 10 This method of selecting weights gives us a synthetic control unit that resembles the treated country in terms of pre-reform growth in GDP, productivity, and wages, and in terms of the pre-reform levels of the labor share and capital formation.

In the case we're considering, the matching procedure assigns a weight of 0.026 to Belgium, a weight of 0.527 to France, a weight of 0.059 to Ireland, a weight of 0.357 to Italy, a weight of 0.031 to the United Kingdom, and weights of zero to the other control countries.

\section{B.7.2 Difference-in-Differences Specifications}

This section reiterates and expands on the explanation of our regression specifications given in Section 4

After constructing a synthetic control unit for each country-reform, we then pool together all of our country-reforms and synthetic control units, and run difference-in-differences regressions comparing the outcomes of the treated and control groups before and after the codetermination reforms. The regression equation is as follows:

$$
y_{i k}=\alpha_{i}+\beta_{k}+\theta_{\text {Year }(i k)}+\sum_{s=-10, s \neq-1}^{10} \tau_{s}^{\text {Treated }} \times \mathbb{1}[k=s] \times \text { Treated }_{i}+\varepsilon_{i k},
$$

where $y_{i k}$ denotes the outcome for country-reform $i$ in year $k=t-$ reformyear $_{i}$ relative to the reform occurring in reformyear ${ }_{i}$ (the reform year for synthetic control units is set equal to their respective country-reform's reform year). The $\alpha_{i}$ are unit (country-reform) fixed effects, $\beta_{k}$ are event time fixed effects, $\theta_{\text {Year }(i k)}$ are calendar year fixed effects (e.g. "1975"), $\mathbb{1}[k=s]$ is an indicator for being in the $s$ th year relative to the reform, and Treated $i$ is an indicator for unit $i$ being a treated country-reform. The $\tau_{s}^{\text {Treated }}$ are the coefficients of interest, and represent effects relative to the omitted $s=-1$. Standard errors are clustered at the country-reform level.

In addition to plotting the full set of dynamic coefficients $\tau_{s}^{\text {Treated }}$, we also report average pre-reform and post-reform coefficients, which are $\tau_{\text {Pre }}^{\text {Treated }}$ and $\tau_{\text {Post }}^{\text {Treat }}$ in the following regression:

$y_{i k}=\alpha_{i}+\beta_{k}+\theta_{\text {Year }(i k)}+\tau_{\text {Pre }}^{\text {Treated }} \times\left(\mathbb{1}[k<-1] \times\right.$ Treated $\left._{i}\right)+\tau_{\text {Post }}^{\text {Treated }} \times\left(\mathbb{1}[k \geq 0] \times\right.$ Treated $\left._{i}\right)+\varepsilon_{i k}$,

where notation is the same as above. Due to the small number of clusters, we report p-values for the pre-reform and post-reform coefficients calculated using the wild bootstrap method,

\footnotetext{
${ }^{10}$ Using the synth command in Stata (Abadie, Diamond, and Hainmueller, 2011).
} 
following Cameron, Gelbach, and Miller (2008) and using the code developed by Roodman, Nielsen, MacKinnon, and Webb (2019).

In addition, we report average post-reform coefficients calculated using the imputation methodology developed by Borusyak, Jaravel, and Spiess (2021), which deals with problems arising when two-way fixed effects models are used in contexts with heterogeneous treatment times, like the context we consider. The imputation methodology proceeds as follows. First, we obtain estimated unit and time effects ${\hat{\alpha^{\prime}}}_{i}$ and $\hat{\beta}^{\prime}{ }_{k}$ from a regression of the outcome variable on unit and time fixed effects, for untreated observations only:

$$
y_{i k}=\alpha_{i}^{\prime}+\beta_{k}^{\prime}+\varepsilon_{i k}
$$

where notation is as above, and the regression is restricted to observations $i k$ that satisfy Treated $_{i}=0$ or $k<0$.

These estimated unit and time effects are used to impute a potential outcome in the absence of treatment for each treated observation $i k$, equal to $\hat{\alpha}^{\prime}{ }_{i}+\hat{\beta}^{\prime}{ }_{k}$. This imputed potential outcome is converted into an imputed treatment effect $y_{i k}-\hat{\alpha}^{\prime}{ }_{i}-\hat{\beta}^{\prime}{ }_{k}$, using observation $i k^{\prime}$ s actual outcome. An overall treatment effect for each post-reform period is then calculated by taking the average of the unit-specific treatment effects for that period. Standard errors for these coefficients are calculated using a methodology that clusters at the country-reform level. Coefficients and standard errors calculated using this method are printed in the panels of Figure 3 . 


\section{Online Appendix References}

Adams, Zoe, Louise Bishop, and Simon Deakin. 2016. "CBR Labor Regulation Index (Dataset of 117 Countries)." Centre for Business Research, University of Cambridge .

Adler, Emanuel. 1922. "The Works Council Act in Austria." International Labour Review 5 (3).

Autenrieth, Angela. 2004. "Germany: The One-Third Participation Act Supercedes the LaborManagement Relations Act of 1952." URL https://www .mondaq. com/germany/contractof-employment/27245/the-one-third-participation-act-supercedes-the-labormanagement-relations-act-of-1952.

Bjorheim, Lars. 1974. "The Development of Industrial Democracy in Norway." Conference Paper.

Borusyak, Kirill, Xavier Jaravel, and Jann Spiess. 2021. “Revisiting Event Study Designs: Robust and Efficient Estimation." Working Paper.

Cameron, Colin, Jonah Gelbach, and Douglas Miller. 2008. "Bootstrap-Based Improvements for Inference with Clustered Errors." The Review of Economics and Statistics 90 (3):414-427.

Carley, Mark, Annalisa Baradel, and Christian Welz. 2005. “Works Councils: Workplace Representation and Participation Structures." Eurofound Report .

Degrauwe, Jef, Gerlind Wisskirchen, Gabriella Ormai, Fabrizio Spagnolo, François Cotard, Katja van Kranenburg, Katarzyna Dulewicz, Christian Gersbach, Bernhard Hainz, César Navarro, Döne Yalçin, Melanie Lane, Tomáš Matejovský, and Martina Novysedláková. 2018. "Employee Representation and Information, Consultation and Co-Determination Rights in Europe." Thomson Reuters Practical Law .

ETUI. 2020. “National Industrial Relations." URL https://www.worker-participation.eu/ National-Industrial-Relations/Countries.

Fairris, David and Philippe Ashkenazy. 2010. "Works Councils and Firm Productivity in France." Journal of Labor Research 31 (3):209-229.

Harju, Jarkko, Simon Jäger, and Benjamin Schoefer. 2021. "Voice at Work." NBER Working Paper.

Havlovic, Stephen. 1990. "German Works Councils: A Highly Evolved Institution of Industrial Democracy." Labor Studies Journal 15 (2):62-73.

Hurley, Michael. 1953. "The Belgian Enterprise Councils, 1948-1953." The American Catholic Sociological Review 14 (4):218-229. 
Knudsen, Herman. 2006. "Workplace Representation in Denmark - Structure and Role." HIVA-EZA Conference Paper .

Roodman, David, Morten Nielsen, James MacKinnon, and Matthew Webb. 2019. "Fast and Wild: Bootstrap Inference in Stata using boottest." The Stata Journal 19 (1):4-60.

Sippola, Markku. 2012. "Local Bargaining and Codetermination: Finnish Experience in Comparative Perspective." European Journal of Industrial Relations 18 (1):53-69.

Van het Kaar, Robbert. 1997. "Amendment of the Dutch Works Councils Act: a few surprises." URL https://www . eurofound. europa. eu/publications/article/1997/amendment-ofthe-dutch-works-councils-act-a-few-surprises.

- 2007. The Forgotten Resource: Corporate Governance and Employee Board-Level Representation. The Situation in France, the Netherlands, Sweden and the UK, chap. Corporate Governance and Employee Board-Level Representation in the Netherlands: Executive Summary. Hans Böckler Stiftung.

Victorin, Anders. 1979. "Co-Determination in Sweden: The Union Way." Journal of Comparative Corporate Law and Securities Regulation 2:111-140.

— 2000. "Employee Participation on the Company Board: The Swedish Experience." Company Law Reform in OECD Countries: A Comparative Outlook of Current Trends .

Visser, Jelle. 2021. “OECD/AIAS ICTWSS Database: Detailed Note on Definitions, Measurement, and Sources." OECD . 